\title{
A Later Prehistoric Settlement and Metalworking Site at Seafield West, near Inverness, Highland
}

\author{
Michael Cressey* and Sue Anderson* \\ with contributions by
}

Ann Clarke, Trevor Cowie, Fraser Hunter, Andrew Heald, Katherine Eremin, Melanie Johnson, Ruth Pelling, Ian Mack and Gerry McDonnell

Illustrations by George Mudie, Alan Braby and Shelly Werner.

*CFA Archaeology Ltd, Old Engine House, Eskmills Park, Musselburgh, EH21 7PQ

Scottish Archaeological Internet Report 47, 2011 www.sair.org.uk 
Published by the Society of Antiquaries of Scotland, www.socantscot.org.uk with Historic Scotland, www.historic-scotland.gov.uk and the Council for British Archaeology, www.britarch.ac.uk

Editor Helen Bleck

Produced by Archétype Informatique SARL, www.archetype-it.com

ISBN: 9780903903523

ISSN: $1773-3803$

Requests for permission to reproduce material from a $S A I R$ report should be sent to the Director of the Society of Antiquaries of Scotland, as well as to the author, illustrator, photographer or other copyright holder.

Copyright in any of the Scottish Archaeological Internet Reports series rests with the SAIR Consortium and the individual authors.

The maps are reproduced from Ordnance Survey material with the permission of Ordnance Survey on behalf of The Controller of Her Majesty's Stationery Office. (C) Crown copyright 2001. Any unauthorised reproduction infringes Crown copyright and may lead to prosecution or civil proceedings. Historic Scotland Licence No. GD 03032G, 2002.

The consent does not extend to copying for general distribution, advertising or promotional purposes, the creation of new collective works or resale. 


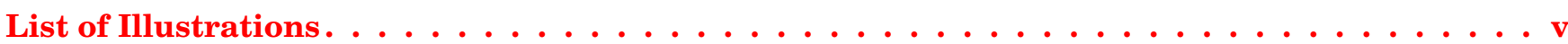

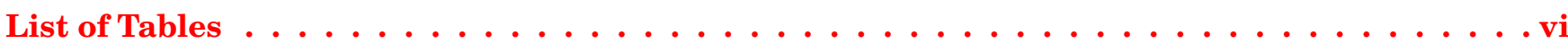

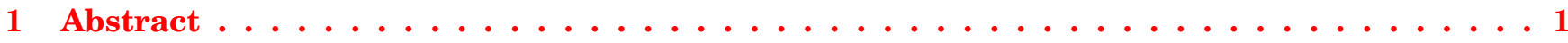

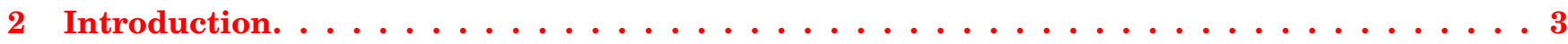

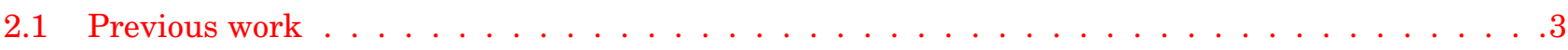

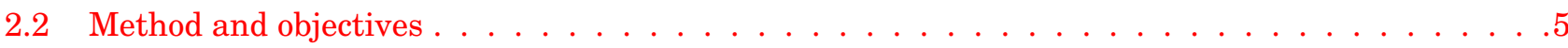

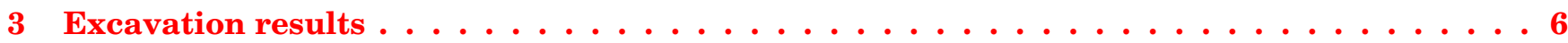

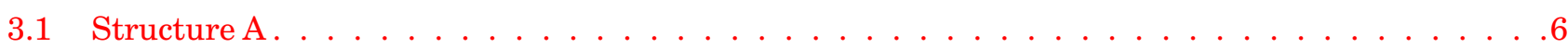

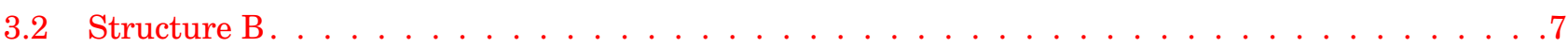

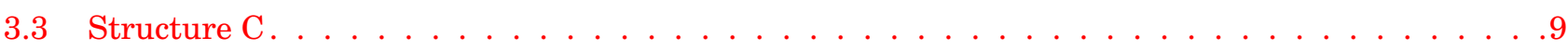

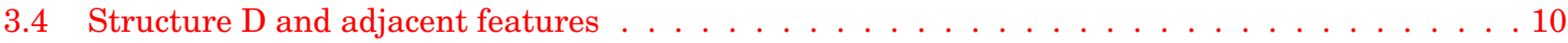

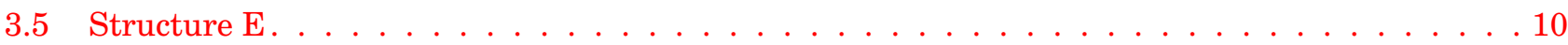

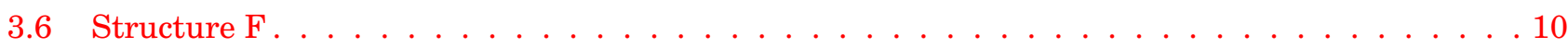

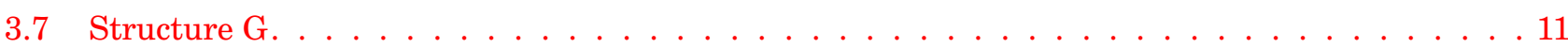

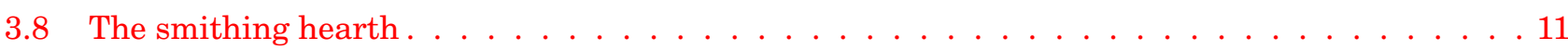

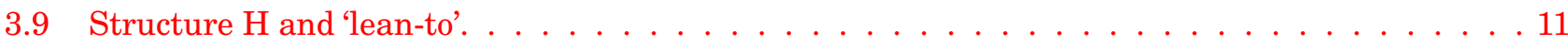

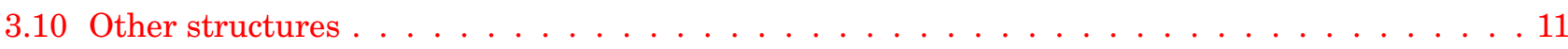

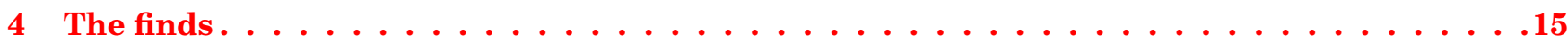

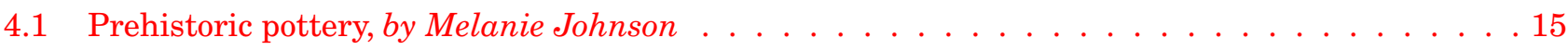

4.2 Coarse stone artefacts, by Ann Clarke . . . . . . . . . . . . . . . . . . . . 15

4.3 Metal and glass objects, by Fraser Hunter . . . . . . . . . . . . . . . . . . . . . 17

4.4 Ironworking debris, by Andrew Heald, Gerry McDonnell and Ian Mack . . . . . . . . . . . . . 20

4.5 Fragments of Bronze Age sword moulds, by Trevor Cowie with Katherine Eremin . . . . . . . . . 24

4.6 Fired clay, by Fraser Hunter . . . . . . . . . . . . . . . . . . . . . . . . . . . . . 27

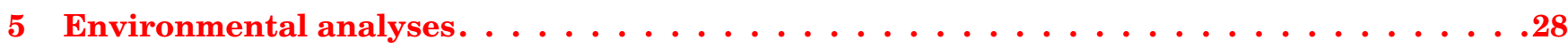

5.1 Bone, by Sue Anderson . . . . . . . . . . . . . . . . . . . . . . . 28

5.2 Charred plant remains, by Ruth Pelling . . . . . . . . . . . . . . . . . . . 28

5.3 Charcoal, by Michael Cressey . . . . . . . . . . . . . . . . . . . . . . . . . . 32

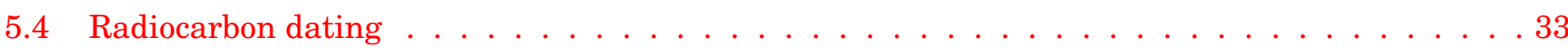

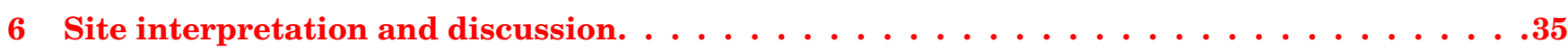

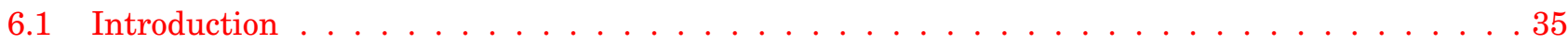

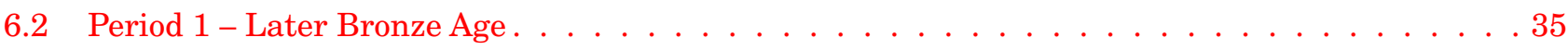

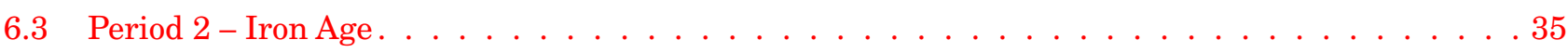

6.4 The settlement and its setting within the landscape. . . . . . . . . . . . 36 


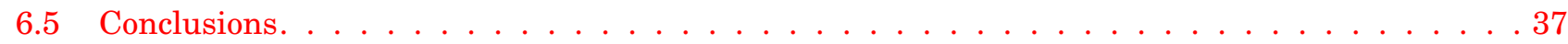

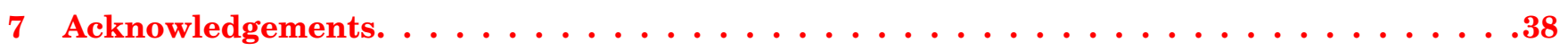

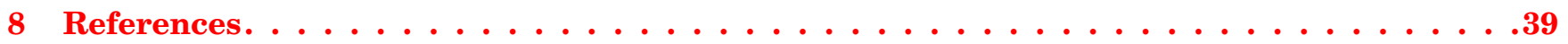

Appendix 1 Roman finds from the Moray Firth . . . . . . . . . . . . . . . . . . . .42

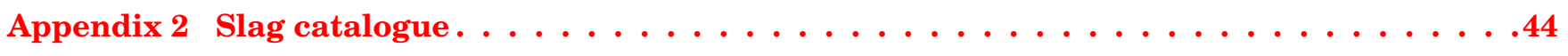




\section{LIST OF ILLUSTRATIONS}

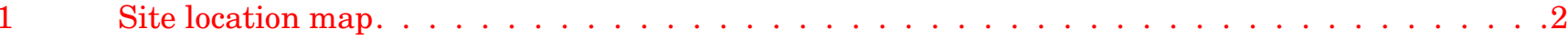

2 Aerial photograph showing crop-mark features . . . . . . . . . . . . . . . . . .

Site plan . . . . . . . . . . . . . . . . . . . . . . . . . . . 4

Sections of ring-groove Structure A and penannular ditch of Structure B . . . . . . . . . . . . . . 6

Sections of ring-ditch Structure $\mathrm{C}$ with pit and hearth features, and of pit 152 . . . . . . . . . . .

Structure G, post-hole arrangements . . . . . . . . . . . . . . . . . . . 12

Section through hearth and adjoining post-hole in Structure G. . . . . . . . . . . . . . . . . 13

Sections of post-holes associated with Structure I . . . . . . . . . . . . . . . . . . 14

Pottery . . . . . . . . . . . . . . . . . . . . . . . . . 15

Coarse stone objects . . . . . . . . . . . . . . . . . . . . . 16

Metal finds . . . . . . . . . . . . . . . . . . . . . . . . . . 18

Distribution of Roman finds within the Moray Firth region . . . . . . . . . . . . . . . . 19

Analytical section through hearth slag . . . . . . . . . . . . . . . . . . . . 22

Fragments of BA leaf-shaped sword moulds . . . . . . . . . . . . . . . . . . 24

Graph showing the distribution of calibrated radiocarbon dates . . . . . . . . . . . . 33 


\section{LIST OF TABLES}

1

Slag by type and provenence . . . . . . . . . . . . . . . . . . . . 21

Quantitative chemical analyses by SEM . . . . . . . . . . . . . . . . . . . 23

Charred plant remains from Structure B. . . . . . . . . . . . . . . . . . . . . 29

Charred plant remains from occupation layer 034 and pit 381 in Structure C . . . . . . . . . . 30

Charred plant remains from Structure G/H . . . . . . . . . . . . . . . . . 31

Charred plant remains from other features . . . . . . . . . . . . . . . . . . . . 32

Charcoal species and total weight. . . . . . . . . . . . . . . . . . . 32

Comparative species abundance derived from Seafield West 1 and 2 and Beechwood Farm. . . . 33

Radiocarbon dating results . . . . . . . . . . . . . . . . . . . . 34 


\section{$1 \quad$ ABSTRACT}

Construction in 1996 at a major retail development site close to Inverness, Highland resulted in the destruction of two known cropmark sites. One set of cropmarks was found to be associated with a Bronze Age log-boat burial site and the results of the ensuing excavation are published elsewhere (Cressey \& Sheridan 2003). The excavation of a second area of cropmarks forms the subject of this publication. The archaeological remains consisted of a series of negative features, post-holes and annular ditches which form parts of at least nine separate structures of a later prehistoric unenclosed settlement.
A mould fragment indicated Late Bronze Age sword production in the vicinity. A palisaded enclosure produced a copper-alloy brooch that is a rare find for the region. Evidence of copper-alloy objects and metalworking from a smelting hearth and slags show that the occupants were of some status. Some of the structural and artefactual evidence compellingly points to an in situ ironworking workshop. A large cache of smithing charcoal found in association with a smelting hearth was radiocarbon dated to $180 \mathrm{BC}-\mathrm{AD} 70$ and represents one of the few dated in situ Iron Age ironworking episodes in Scotland. 

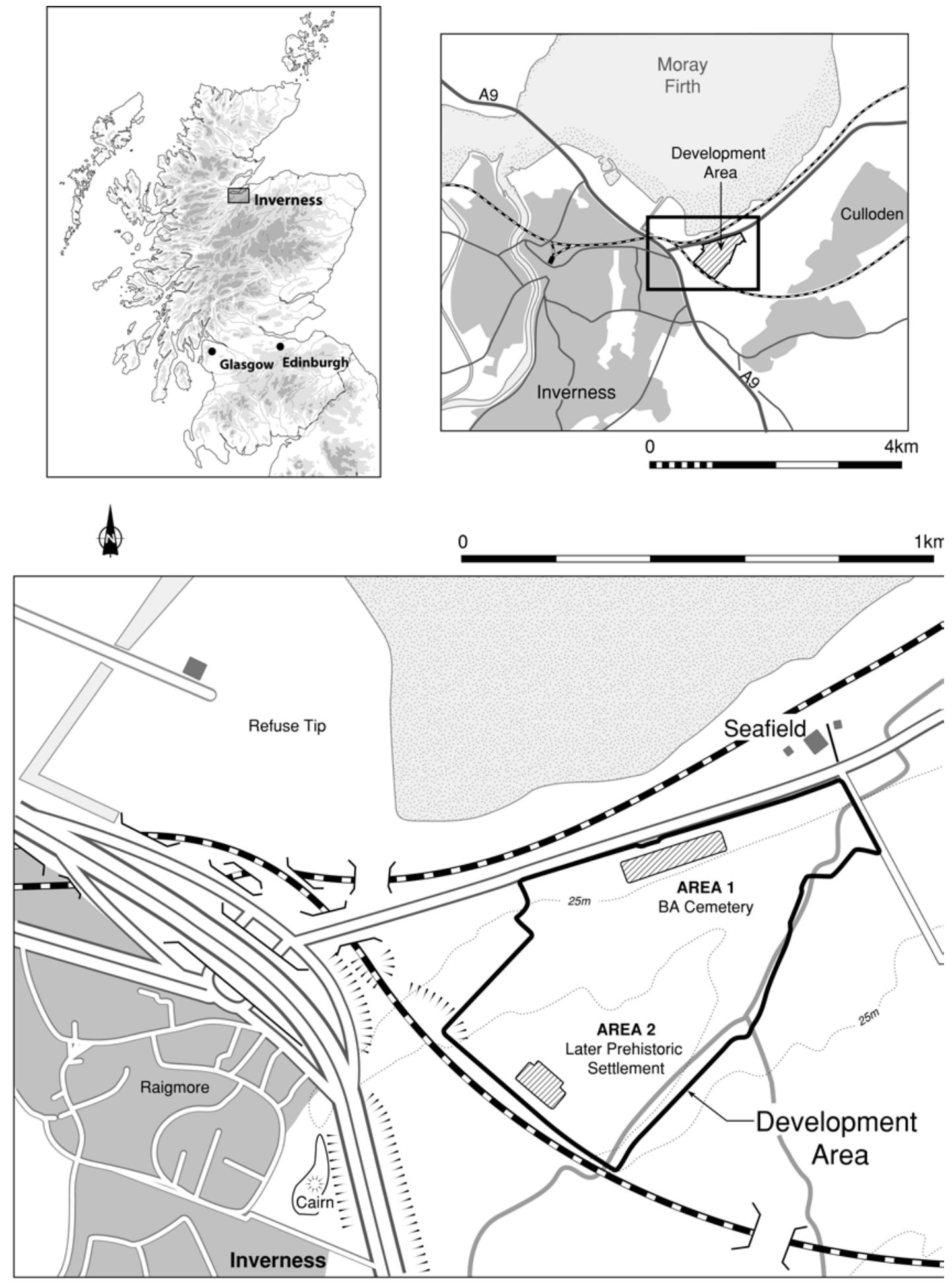

Illus 1 Site location map 


\section{INTRODUCTION}

Rescue excavation at Seafield West, on a cropmark site to the east of Inverness (NGR: NH 694 445) was undertaken by the Centre for Field Archaeology (CFA), University of Edinburgh, between July and August 1997. The development encompassed an area of approximately 30 hectares and was scheduled for development as a retail and business park (illus 1). The project was funded by Inverness Retail and Business Park Ltd.

Excavation, conducted in April and July 1996, of a Bronze Age cemetery site (Area 1) within the proposed development site boundary has been published previously (Cressey \& Sheridan 2003).

\subsection{Previous work}

Situated to the north of the Bronze Age cemetery site on flat cultivated land adjacent to the Inverness to Perth railway line (Area 2), a series of features had previously been recognised as cropmarks (NMRS ref: NH64NE 106, Stonyfield). Both circular and linear features are represented, with their darker fills clearly contrasting against the gravel-rich subsoil (illus 2). In places these features are obscured by deeper topsoil and clay subsoil. Particularly clear on the aerial photograph are three circular features which appeared to be ring-ditch houses, one to
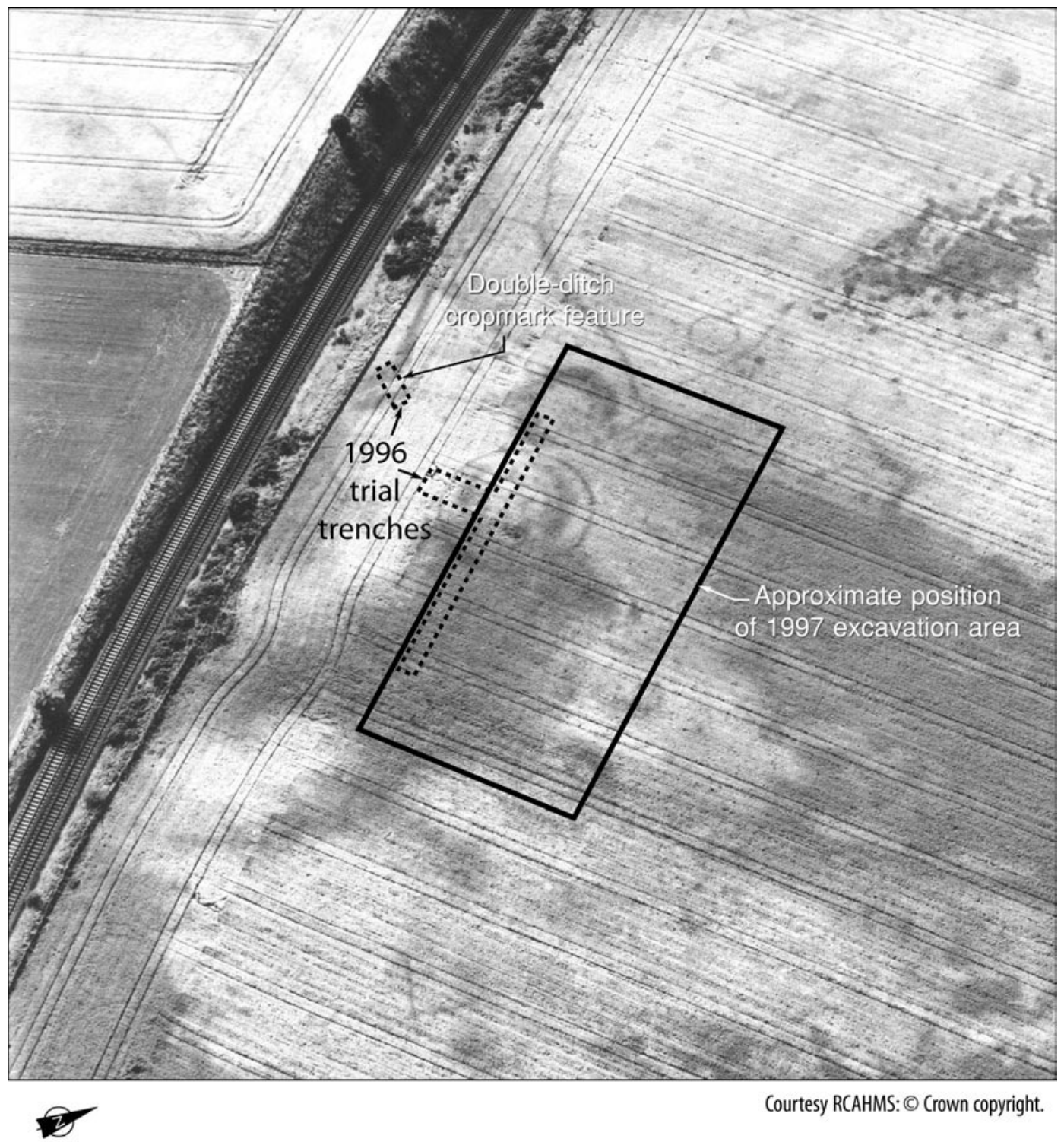

Courtesy RCAHMS: @ Crown copyright.

Illus 2 Aerial photograph showing crop-mark features 


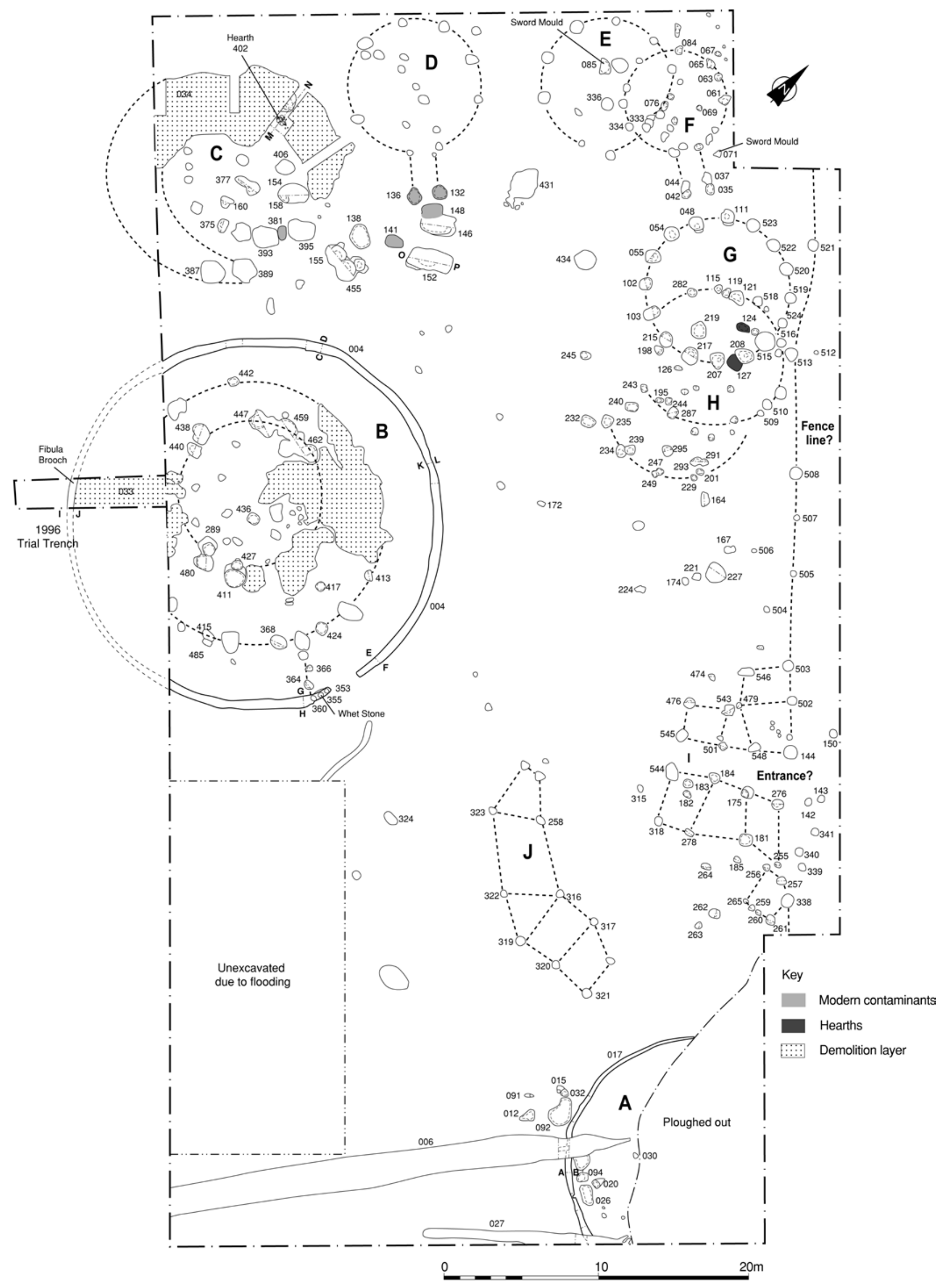

Illus 3 Site plan 
the east and two to the west; the largest of these appeared to be surrounded by a palisade or wall line. Linear features to the north-east of the cropmark complex are attributed to natural palaeochannels within the subsoil.

Episodes of fieldwalking undertaken by local archaeologist Mr Allen Ross had produced a collection of worked flint from within the development area. An examination of this material was undertaken at Inverness Museum by Dr Bill Finlayson and a full report on his results is held in the site archive. In summary, the material appears to represent Mesolithic, Neolithic and Early Bronze Age activity. Two gun flints were also recovered. A large proportion of the material is ascribed to Mesolithic activity. Finlayson noted the presence of platform cores and bladelets along with core rejuvenation, as well as a few microliths, although most of the pieces catalogued as such are unretouched bladelets and bladelet fragments.

Known sites recorded in the NMRS included a ring-ditch and pit alignment (NH64NE 040); two other ring-ditches (NH64NE 059 and 178); and finds of flint, pottery and beads (NH64NE 083).

\subsection{Method and objectives}

Due to the size of the area, which encompassed about 30 hectares, an appropriate sampling strategy was required in order to provide a representative sample of the archaeological potential of the development site. A systematic programme of fieldwalking was carried out, followed by geophysical survey centred across the known area of cropmarks and on land to the south of them. This approach was considered to be the most appropriate strategy in dealing with such a large area of land, where total excavation would not be feasible.

The main objectives of this stage of the fieldwork were to determine the precise location of the features identified from cropmark evidence, to establish the nature, preservation and quality of the surviving remains, and to establish whether the artefacts found within the area represented occasional casual losses or originated from completely ploughed-out sites.

\subsubsection{Fieldwalking and geophysical survey}

Area 2 was fieldwalked using $10 \times 10 \mathrm{~m}$ grids in order to isolate any patterns in artefact distribution. The finds recovered comprised occasional worked flint, 19th-century pottery and glass, and a blue glass bead of uncertain age. The results confirmed that as a result of modern ploughing there was no visible pattern to lithic distribution.

Following fieldwalking, a geophysical survey was carried out by the Department of Geophysics, Edinburgh University using resistivity and fluxgate gradiometry over an area encompassing $13,700 \mathrm{~m}^{2}$ (Cressey \& Finlayson 1996). The geophysical survey grids were centred on where the cropmarks were clearest, and beyond to define the limits of any archaeological anomalies. The gradiometer results confirmed a dense distribution of anomalies of likely archaeological origin spread well beyond the confines of the cropmarks. The magnetometer survey produced evidence of up to five annular features. The clearest results corresponded well with the large concentric ditch (context 004, illus 3). Other anomalies were interpreted as possible post-holes, pits and fire-spots.

\subsubsection{Trial trenching (1996)}

Two trial trenches were positioned to investigate the large annular features located on the aerial photographs and confirmed by geophysical survey results. The first trench was located to provide a transect across the larger circular cropmark feature; it also confirmed the presence of a palisade ditch (Structure B2 below). Within what was then presumed to be a large post-built structure, a layer of charcoal-rich soil was initially considered to be the remains of an occupation layer. Several large pits, fire-spots and a series of post-holes, with no discernible spatial pattern, were also identified. A notable find from the palisade ditch was a well-preserved copper-alloy fibula brooch dating to the 1st-2nd centuries $\mathrm{AD}$ (see Section 4.3).

The second trench was placed to investigate a double-ditch cropmark feature close to the railway line (illus 2). This investigation showed that the railway had truncated what appears to be a curvilinear feature $0.15 \mathrm{~m}$ wide and $0.16 \mathrm{~m}$ deep. A ditch measuring $0.5 \mathrm{~m}$ deep and $1.15 \mathrm{~m}$ wide crossed the trench diagonally. This trench could not be reopened subsequently as it had been buried beneath an earthwork bund screening the development site from the railway line.

The results of this evaluation confirmed the nature and extent of the archaeological features within this area of the development. As they would be totally destroyed by the development footprint, Highland Council's Archaeology Unit recommended that these features and the area surrounding them be more fully recorded well in advance of the proposed development works; an excavation season was thus planned for the following year. 


\section{EXCAVATION RESULTS}

Prior to the arrival of the archaeological team in 1997, the earthwork bund had been constructed on the south side of the site from topsoil removed from the site without archaeological supervision. The topsoiled area was then used by the contractor responsible for preparatory works as a temporary stockpile for subsoil. The subsoil mound was then removed by mechanical excavator by the same contractor, again without archaeological supervision, leading to severe truncation of archaeological features in the southern half and at the northeast corner of the area subsequently defined for archaeological excavation. Large areas had to be hand-cleaned to remove a compact deposit of clay introduced as part of the foregoing operations. This led to serious time pressures towards the end of the excavation. Another factor that affected progress was the presence of relict palaeochannels, partly infilled with a natural impervious blue-grey clay; as a result, the site was prone to serious waterlogging after heavy rain.

A single excavation trench, measuring $85 \mathrm{~m} \times 50 \mathrm{~m}$ $\left(4400 \mathrm{~m}^{2}\right)$, was opened to investigate the features revealed by aerial photography, geophysical survey and trial trenching. The area in which the brooch had previously been found could not be further investigated as it lay under the earthwork bund screening the site.

The principal structures recorded are shown on illus 3. They included a ring-groove structure (Structure A) in the north-east corner of the trench, a double post-ring structure (Structure B) situated on the southern boundary, and Structure C. Immediately north of Structure C, running in a clockwise direction, are the remains of additional post-built structures (Structures D-H) and possible rectilinear post-built structures (I-M).

\section{$3.1 \quad$ Structure A}

Only the southern and western portions of this ring-groove structure survived (illus 3), at least twothirds of its interior having been removed when the site was originally stripped of topsoil. Three sections were cut through this groove (017). The sides of the groove itself were vertical and up to $0.4 \mathrm{~m}$ deep and $0.44 \mathrm{~m}$ wide, with a rounded and tapered base (illus 4a). Its fill consisted of a black, charcoal-rich, sandy silt. The ring-groove, as extrapolated, would
A
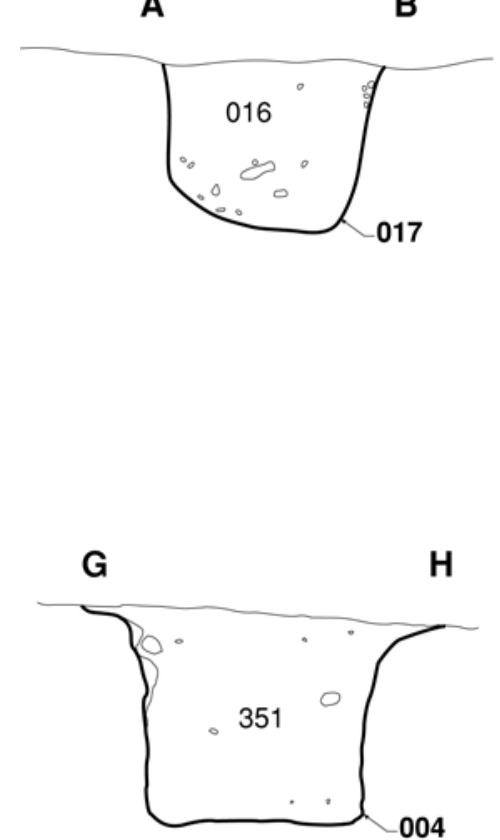

c
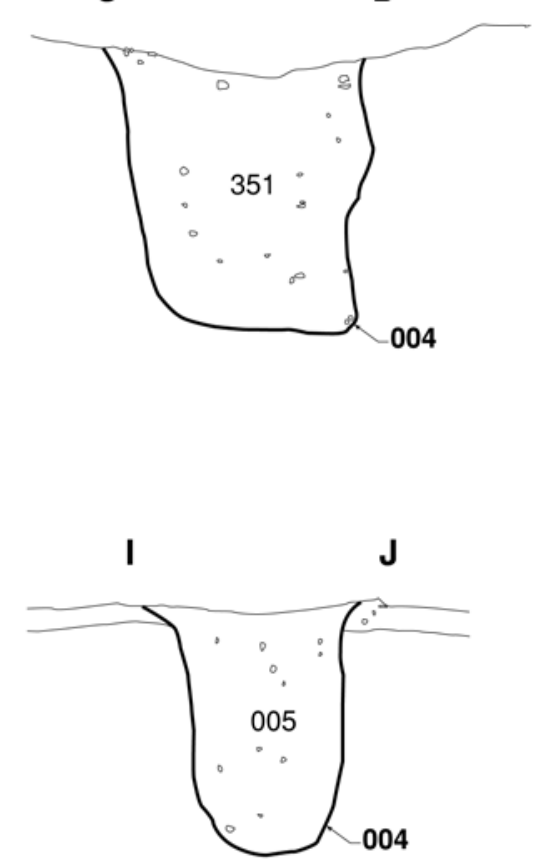

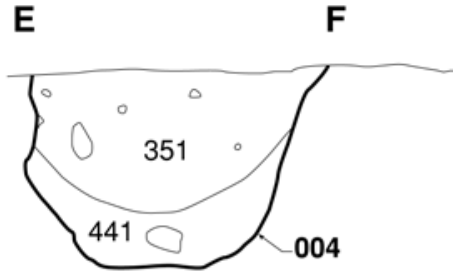

E

0

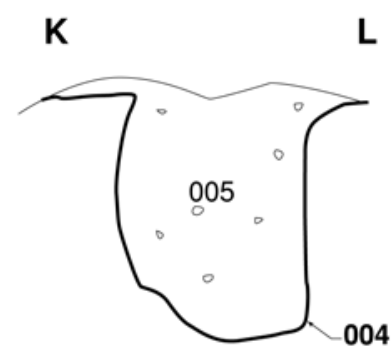

Illus 4 Sections of ring-groove Structure A and penannular ditch of Structure B 
originally have enclosed an area with a diameter of $16.7 \mathrm{~m}$. Heavy truncation had removed any evidence of floor deposits and the entrance to this structure was also presumed to have been lost. The surviving section of the ring-groove was cut at one point by a recent field boundary ditch associated with a former hedge line (006) and by a shallow linear feature of unknown age (027).

A group of small pit or post-hole features was recorded either side of the ring-groove, but they are undated and their relationship with the structure and each other is uncertain. Two of the features, 026 and 094, contained tiny fragments of unclassified slag, and a piece of unburnt bone was found in 020 , but no other finds were recovered. Features to the outside of the ring ditch were all less than $0.1 \mathrm{~m}$ deep. Such shallow, irregular features could be the result of animal activity, perhaps during the lifetime of the structure.

\section{$3.2 \quad$ Structure B}

'Structure B' was the largest feature recorded at this site (illus 3 ) and is clearly visible on the aerial photograph (illus 2), on which a number of internal features can be seen within the penannular ditch. Part of this structure was identified during trial trenching in 1996 (Cressey \& Finlayson 1996), when a T-shaped trial excavation trench was placed directly over the large cropmark shown in illus 2 . In 1997 during the construction site preparation works, part of the south-western side of the structure was buried by a large bund of earth and no further work could be carried out in this area.

Excavation of the accessible part of this structure revealed a series of post-holes and pits, cut into compact clay subsoil on the eastern side and sand subsoil on the western and southern sides. The pattern of post-holes was neither regular nor complete, thus limiting understanding of the relationship between these features. A large spread of carbon-rich soil (033) was interpreted as the remains of a possible destruction layer which, due to disturbance by the contractor creating the bund, was now heavily truncated and survived best in the northern half of the structure between the inner and outer ring of post-holes.

\subsubsection{Penannular ditch}

The penannular ditch (004) measured $24 \mathrm{~m}$ in diameter and, on average, was $0.4 \mathrm{~m}$ wide and $0.6 \mathrm{~m}$ deep and filled by a brown sandy soil (illus $4 \mathrm{~b}-\mathrm{g}$ ). No post-holes or other features were recorded other than those found at the entrance. The single entrance, situated on the east side, was $1.6 \mathrm{~m}$ wide. Its southern terminus was found to contain a series of fills. A primary deposit of compact silt with subangular stones (099) was sealed by stiff clay (096) which in turn underlay a compacted dark brown sandy silt including fragments of charcoal (005). The primary deposit may have acted as packing for three post features which were situated on the southern side of the entrance $(353,355,360)$. A single-entity sample of Quercus sp. charcoal from the fill of the slot (351) produced a radiocarbon date with a calibrated range of $110 \mathrm{BC}-\mathrm{AD} 140$ (2 $\sigma$; AA-35531). Also on the southern side of the entrance a narrow groove (098) was identified running along the outer edge of the ditch. This groove measured $0.32 \mathrm{~m}$ deep and $0.09 \mathrm{~m}$ wide, and tapered steeply inwards to a narrow base only $0.2 \mathrm{~m}$ wide. It possibly represents the latest phase of activity identifiable within this feature and post-dated the main phase of sediment accumulation within the ditch. A whetstone (illus 10c) was found in post-hole 355 , and a relatively large quantity of slag (two smithing hearth bottoms, tapped slag and smithing slag amounting to almost $1.5 \mathrm{~kg}$ ) was recovered from the fill of the southern terminus (096) which overlay post-hole 355. Small quantities of undiagnostic burnt animal bone were also found in the entrance.

\subsubsection{Outer post ring}

Post-holes running concentrically within the ditch include 415/485, 368, 424, 413 and 442, defining a ring some $17-18 \mathrm{~m}$ in diameter. Post-holes 364, 366 and a third unexcavated feature appear to represent a partition to the left of the entrance. Post-hole 368 contained a small quantity of slag, but none of the other excavated features in this ring contained finds. A post-hole (417) between this ring and the inner ring contained charcoal, a single-entity sample of which was dated to cal 50 BC-AD 220 (2 $\sigma$; AA-35530).

\subsubsection{Inner post ring}

Post-holes 289, 480, 427, 411 represent the inner post ring on the south-east side with post-holes 440, 438 and conjoined postholes 447, 459 and 462 on the north-west side. Sealing the latter post-holes was demolition layer 033, which contained half a rotary quern and a hammer stone (see Section 4.2). The post-holes formed a rough circle almost $10 \mathrm{~m}$ in diameter. Smaller post-holes within the interior formed no coherent pattern but may represent the foundations of partitions belonging to this structure. Finds associated with this ring were fragments of slag from post-hole 411 and burnt animal bone and ?worked antler from 427. A single-entity sample of Betula sp. charcoal from post-hole 447 provided a radiocarbon date with a calibrated range of $170 \mathrm{BC}-$ AD 90 (2 $\sigma$; AA-35529).

\subsubsection{Interpretation}

Within the limitations of the excavation results, three possible interpretations of this structure are 
presented below in an attempt to elucidate how this arrangement of slots and post-rings may have occurred, in the light of conventional knowledge of roundhouse construction.

Interpretation 1: a single post-built structure within a penannular ditch

Disconformities within the asymmetry of the inner and outer rings tempt the theory that a single structure demarcated by the inner ring was present more or less at the centre of the penannular ditch. The inner ring was not symmetrical with either the outer ring or the penannular ditch and invites the theory that this was a single timber-built structure sharing more or less the same diameter as House G. The outer ring of features could represent the position of a stockade fence where upright posts held hurdle panels to keep livestock away from the domestic areas and grazing on the thatched roof. The area between the stockade fence and the penannular ditch could have contained a folding area for livestock. The penannular ditch itself may have held a timber fence, despite the lack of post-hole evidence; upright timbers in the form of a palisade seem the most likely explanation for its profile.

Interpretation 2: a double-ring structure with penannular ditch

The argument for a single, double-ring post-built structure would require the inner ring to have been the main load-bearing structure, which would necessitate a ring-beam arrangement. The outer ring, although not load-bearing, would require shorter upright posts and hurdle or turf panels within the structure.

If we accept that the building was a double-ring post-built structure then it was very large indeed. Massive roundhouses did certainly exist. Pope (2003) mentions that there are twenty structures recorded in northern Britain that have a diameter of $15 \mathrm{~m}$ or above. These are not known before the Late Bronze Age but do continue into the Roman Iron Age. Nevertheless, structures in excess of $15 \mathrm{~m}$ are very rare $-99 \%$ of circular structures in northern Britain have a diameter of less than $15 \mathrm{~m}$ - and no published structures are known with a diameter in excess of 19m (contra Bersu 1947, 88).

Interpretation 3: more than one phase of construction

This interpretation is based on the presence of layer 033 on the east side of the structure. The layer appears to cover the inner ring, whilst running concentrically with the outer ring, perhaps indicating that the latter was still standing when it formed. The inner ring could therefore be an earlier structure which was replaced by a larger post-ring roundhouse inside a penannular ditch. However, the range of both radiocarbon dates and dating from small finds suggests that the structure was relatively short-lived.

\section{Discussion}

Structure B outer ring has a diameter of $17.5 \mathrm{~m}$, which would put a structure of this size towards the larger end of roundhouse sizes. Bersu's search for the 'big buildings of the aristocracy' was manifested at Scotstarvit (Bersu 1947), where he excavated what he saw as a 19m-diameter triple-ring structure. Reinterpretation of the site suggests a $13 \mathrm{~m}$ diameter, re-built, double-ring structure with an enclosing, concentric fence or palisade (Pope 2003, fig. 4.25). This becomes clear when the position of the doorpost is considered, and also the nature of Bersu's inner-ring - a wall-slot - implies load-bearing continuous walling, a feature only rarely found in the interior of a structure. If the Seafield West structure is interpreted in the same way, it was considerably larger than Scotstarvit.

Apart from Scotstarvit, other 'substantial' timber roundhouses have been identified in recent years. At the Candle Stane, near Insch, Aberdeenshire (Cameron 1999) a ring-groove with an extrapolated diameter of $c 15.5 \mathrm{~m}$ was found to contain up to three concentric rings of post-holes. House 1 at Bannockburn (Rideout 1996, fig. 18) is very similar on plan to Seafield Structure B; this structure was dated to the 6 th/5th centuries BC and is therefore some 400 years earlier than the Seafield one. The incomplete remains of a timber structure below the Fairy Knowe broch at Buchlyvie, Stirlingshire (Main 1998) are open to a number of interpretations, but one of these, 'Option 4', could be a $21 \mathrm{~m}$-diameter palisaded house suggested, like Seafield, to date to the 1st centuries BC/AD. Culduthel Farm, Inverness, provides the geographically closest parallel, with a large palisaded house some $20 \mathrm{~m}$ in diameter (Murray 2006). A large (c 15m diameter), heavily truncated palisade at Birnie, Moray (Hunter 2003, fig. 6) has been interpreted as a stock enclosure, although some post-holes survived internally.

A palisaded enclosure identified at Wardend of Durris, 6km south-east of Banchory, Aberdeenshire (Russell-White 1995, Enclosure 2) was interpreted as an enclosure around a series of post-ring structures, although potentially a larger concentric inner ring could also be interpreted amongst the myriad post-holes there. However, perhaps a 26m diameter is stretching the size of these substantial structures a little too far, if it is assumed they were completely roofed. A palisaded enclosure was also identified at Balloan Park, Inverness (Wordsworth 1999), but this was $30 \mathrm{~m}$ in diameter.

On balance, a smaller structure comparable with others on the site, but separated from them by a palisade and internal timber fence (ie interpretation 1) seems the most likely explanation for the ground plan. This is suggested as the most probable interpretation due to the presence of an apparent entrance porch on the inner ring, marked by two 

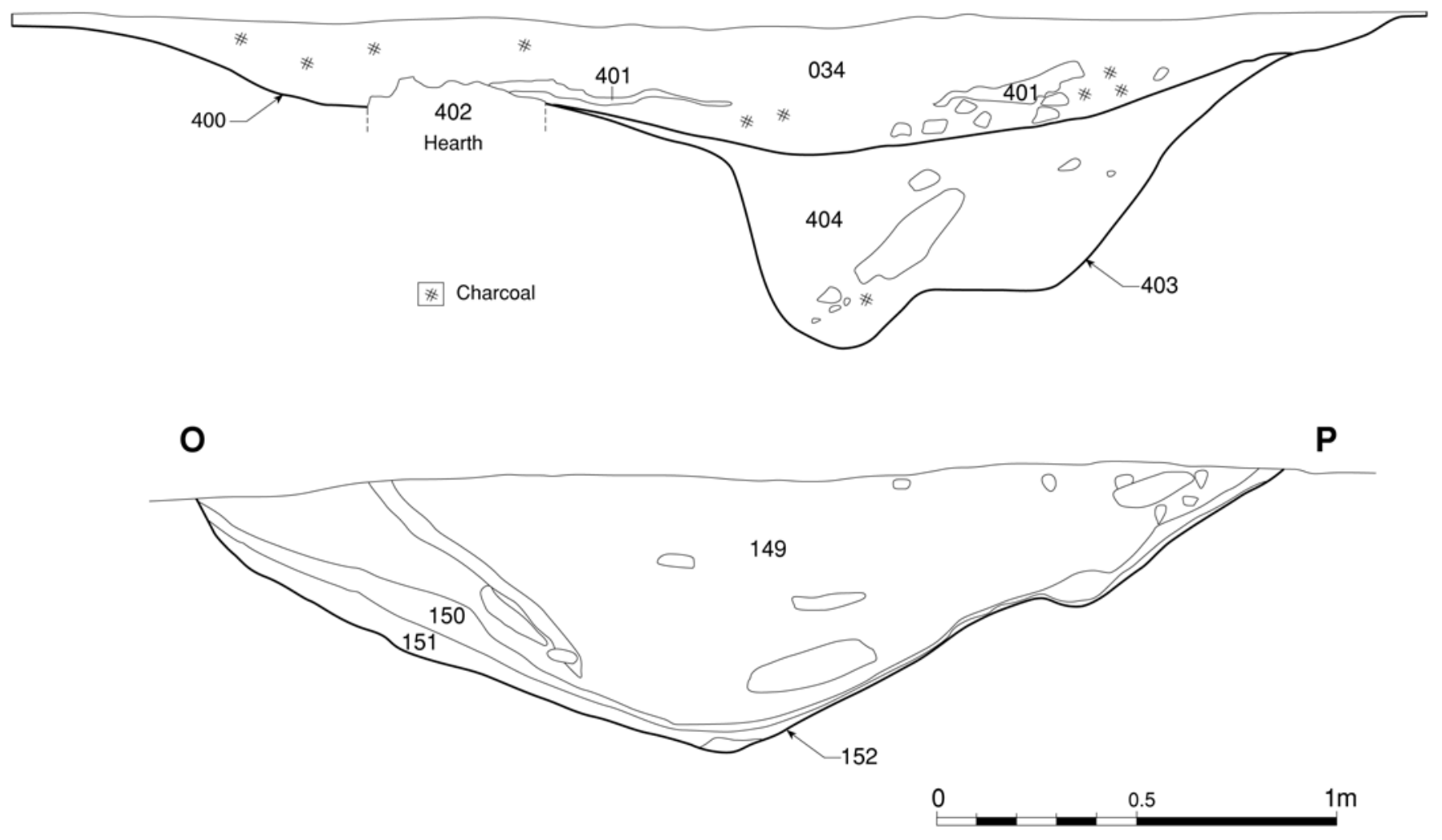

Illus 5 Section through ring-ditch Structure C with pit and hearth features (BS3) and pit 152

sets of double post-holes to the south-west, which would not be required if the ring formed an inner circle to a larger structure. However, this does not deny the possibility that the inner ring structure was slightly earlier than the rest of Structure B and may have stood alone for a while, even though the dating suggests that the structure as a whole lasted perhaps no more than a century.

\subsection{Structure C}

This building was situated immediately to the west of Structure B (illus 3) and showed up clearly as a penannular cropmark on the aerial photographs. The structure was identified during the excavation as a crescentic spread (034) of black silty loam with maximum dimensions of $c 14 \mathrm{~m} \times c 5 \mathrm{~m}$. Incorporated within this layer was a substantial quantity of charcoal with stratified lenses of red ash, which possibly suggests that the sequences were associated with demolition material. Sections were placed through this spread in order to determine its depth, and these revealed an intense layer of fire debris which appeared to be widespread. The depth varied from $0.1 \mathrm{~m}$ at the southern end, through $0.2 \mathrm{~m}$ at the centre. The ditch fill incorporated a bright red layer of peat ash at the north-east section. Finds recovered from this layer included two rimsherds of Iron Age pottery (illus 9b), the shaft of an orna- mented Roman headstud brooch (see Section 4.3.2), and small quantities of slag and burnt bone.

The sections appear to confirm that this was a ditch-like feature (cut 400, illus $5 \mathrm{M}-\mathrm{N}$ ), potentially forming part of a ring-ditch structure. Some of the unexcavated post-holes to the south and east might then represent internal posts. Although no continuing ring-ditch was identified to the south during the excavation, the aerial photographic evidence that it existed is unequivocal and it is assumed that evidence was removed during unmonitored stripping of the area. This structure is therefore interpreted as a possible ring-ditch house of the type discovered at so many later Bronze Age and Iron Age sites in recent years (eg Douglasmuir, Kendrick 1995; Kintore, Alexander 2000 and Cook \& Dunbar 2008; Dryburn Bridge, Dunwell 2007). Potentially the large double pit 155/455, which was recut at least once, could mark the north side of its entrance.

Two features were identified below 034 (illus $5 \mathrm{M}-\mathrm{N})$. A pit (403) to the north side of the section had a near-vertical face on its eastern side, whilst the opposite side sloped gradually. A large stone measuring $0.3 \mathrm{~m} \times 0.1 \mathrm{~m}$ was exposed in section and slumped at an angle of about $30^{\circ}$. Charcoal was present towards the base of the fill. It is possible that the pit was an earlier feature truncated by the ring-ditch (400), although similar features were present in the ring-ditch of Kintore Structure 3 (Alexander 2000, illus 8) and were interpreted as 
structural elements. The two large unexcavated pits on the opposite side of the structure, 387 and 389, could represent the remains of similar features in the base of the missing ring-ditch there, although they would be at the terminus of the ditch in this area.

At the base of the section, a collection of burnt stones (402) was exposed. These were interpreted as the base of a hearth or oven. The hearth lay on the upslope end of the ditch cut, sealed by layer 034 . The fact that it was overlain by so much burnt material seems unlikely to be coincidental. The hearth could possibly have been constructed here after the structure had been demolished, and the ditch filled with debris related to this later use. It is interesting to note that Structure 4 at Kintore (Alexander 2000, 29-31 and fig. 17) consisted of a very similar spread of burnt material, with a similar section, and associated post-holes.

Several pits of variable depth and diameter were excavated within the circumference of the ring-ditch. It is possible that some of the smaller, unexcavated ?post-holes formed an inner ring of posts which belonged to the structure (although if so this would negate the need for the larger post-holes postulated above). Small quantities of slag were recovered from two of the pits (154 and 155) and a layer (161) in this area, and pit 158 contained fired clay. Pit 381 contained unburnt bone which, if not intrusive, may indicate a recent date for this feature; the pit also contained the largest single quantity (by weight) of fired clay from the site.

It seems most likely that the features in this area were the remains of a ring-ditch structure with an inner ring of posts. The structure would have been some $14 \mathrm{~m}$ in diameter, although the possibility that there was a broad outer wall of turf might extend this to incorporate possible entrance post-hole 155 , making it closer to $16 \mathrm{~m}$. Following its demolition, the area seems to have continued in use, with a hearth and various pits being related to this later activity.

\subsection{Structure D and adjacent features}

A group of post-holes lay immediately north of Structure C and formed a roughly circular ring, with a diameter of approximately $9 \mathrm{~m}$ (illus 3 ). The post-holes on the west side of the structure survived best and were seen to be more or less equidistant at $c 2.5 \mathrm{~m}$ apart. No occupation deposits survived within the structure. These pits and post-holes were not excavated. In the absence of any evidence for an outer ring, it is tentatively interpreted as a single ring structure. The entrance may be marked by the two closest post-holes at the south-east side, possibly extending out to post-holes 132 and 136. However, these two features and two other nearby pits (141, 148) produced modern finds, and one of them (141) was certainly of recent date, as a ballpoint pen was recovered from its base.
Sub-rectangular pits 146 and to the south-east were unusual in having shallow V-shaped sections longitudinally, sloping to the centre at an angle of approximately $30-45^{\circ}$ from both ends (illus 5 O-P); they do appear to form a pair but their purpose is unknown. A lead bead (see Section 4.3.3) was recovered from a sample taken from sub-rectangular pit 152, possibly indicating a Roman or later date for the fill. Further to the north-east, large pit 431 contained an iron tool of uncertain type.

\subsection{Structure $E$}

Structure E was demarcated by nine unexcavated features, $c 2.5 \mathrm{~m}$ apart, that formed a circular arrangement with a diameter of about $9 \mathrm{~m}$ (illus 3 ). Like Structure D, this is interpreted as a singlering structure with a possible entrance at the south-east.

No floor deposits survived within this group, but there were at least three pits within the area delimited by the post-holes. One of these (085) was excavated: it measured $0.7 \mathrm{~m}$ in diameter and $0.5 \mathrm{~m}$ deep and had a dark sandy-loam fill which contained a fragment of a mould for a bronze sword (Cowie below). A single-entity sample of charcoal recovered from this feature was radiocarbon dated and indicated a date range of 1260-920 cal BC (2 $\sigma$; AA-35528). Whilst the pit may be associated with the surrounding structure, it is not possible to associate the two with any certainty.

\section{6 $\quad$ Structure F}

A curving line of excavated and unexcavated postholes appears to form a ring, Structure F, including 061, 063 and 065 (illus 3). This group was roughly annular, with a diameter of approximately $7 \mathrm{~m}$. Posts were less regularly spaced, varying between $1.5 \mathrm{~m}$ and $2.5 \mathrm{~m}$ apart. The west side was formed by an arc of post-holes situated in the north-eastern half of Structure E, making it clear that Structures $\mathrm{E}$ and $\mathrm{F}$ could not have been contemporary, but their relationship is unknown. The double post-holes 042/044 and 035/037 to the south-east could mark the position of the entrance. Parallel groups of three unexcavated post-holes on the southern side within the ring could potentially indicate an entrance to another structure which has otherwise disappeared, or may represent partitions within Structure F.

A post-hole within Structure F, 069, contained a sherd of Middle to Late Bronze Age pottery, but like the pit in Structure E, cannot definitively be related to the structure in which it was situated. An unfinished rotary quern came from a post-hole in this area (084); if related, this may suggest a later date for the structure. Another find consisted of a piece of iron slag from post-hole 061 . No occupation deposits survived within this structure. Another fragment of sword mould was found in post-hole/pit 071 to the 
east of this structure. Although only circumstantial evidence, this could suggest that 085 (mentioned above in association with Structure E) was also an external feature related to Structure F, and that this was a Bronze Age structure.

\section{7 $\quad$ Structure $G$}

This post-built structure comprised a series of 16 post-holes (illus 3,6 ), each approximately $1 \mathrm{~m}$ apart. Six of the postholes lay outwith the excavation area but after extending the trench $5 \mathrm{~m}$ northwards, the remaining post-holes were plotted; due to time constraints these were not excavated. The diameter of this structure measured approximately $9.5 \mathrm{~m}$ and the mean diameter of the ten excavated post-holes was $0.87 \mathrm{~m}$ (range $c 0.75-1.1 \mathrm{~m}$ ), with an average depth of $0.53 \mathrm{~m}$. Post-holes 048, 055 and 111 contained packing stones. In general the post-hole fills comprised a grey-brown sand with varying quantities of charcoal. Finds included small quantities of burnt bone, slag and fired clay. No occupation deposits survived. A date was obtained from a single sample of charcoal from post-hole 111 (cal $200 \mathrm{BC}-\mathrm{AD} 50$ at $2 \sigma$; AA-35532). As the posts of this building were so closely spaced, it is suggested that it consisted of a single ring forming the outer wall, since movement between the posts would be restricted. A similar structure was excavated at Tavelty and produced a date range of cal $190 \mathrm{BC}-\mathrm{AD}$ 20 from a carbonised barley grain within one of the post-holes (Alexander 2000, 37).

The entrance is suggested to have been on the south side of the structure represented by post-holes 126, 198, 215 and 217. However, two elongated pits were found on the west side of the structure (035/037 and $042 / 044)$. These features may represent either an earlier or a later phase of entrance, if they did not belong to Structure F (or could even have linked the two together via a short passageway). In theory, either position would have afforded some protection from the winds emanating from the Moray Firth, less than $1 \mathrm{~km}$ to the north.

Feature 124 was a shallow bowl-shaped cut lined with sandstone and granite blocks which contained an ashy, charcoal-rich deposit. It was identified as a possible hearth, although its position close to the eastern side suggests it could also have belonged to putative Structure H. Feature 121 also contained possible hearth debris. Other features identified within the structure may represent partitions within Structure G or could perhaps belong to Structure $\mathrm{H}$.

\subsection{The smithing hearth}

Post-hole 207, in the south-east quarter of Structure G (illus 6), had been re-cut and its secondary fill (125) contained a substantial amount of sizeable lumps of charcoal derived from tooled wood. This charcoal was probably the remnants of a fuel cache for a smithing hearth (127) which cut the edge of adjacent post-hole 208. This hearth (illus 6-7) measured $1 \mathrm{~m}$ $\times 0.95 \mathrm{~m}$ with a depth of $0.3 \mathrm{~m}$ and was edged with sub-angular sandstones up to $0.35 \mathrm{~m} \times 0.2 \mathrm{~m} \times 0.08 \mathrm{~m}$ in size. The internal fill comprised grey-black ash and sand, with lenses of smithing slag present in the upper portion of this deposit. The hearth was stratigraphically later than Structure G. It may conceivably be related to Structure H, which survives as a near-concentric ring of post-holes, if this were the case then the smithing hearth would have been more or less at its centre. A conventional radiocarbon date from a single piece of charcoal weighing $8 \mathrm{~g}$ obtained from fill 125 produced a date range of cal 180 BC-AD 70 (2 $\sigma$; GU-8032).

\subsection{Structure H and 'lean-to'}

This structure was superimposed on the eastern half of Structure G. The feature comprised an arc of sixteen unexcavated and excavated post-holes running from 282 (or possibly 103 as this feature appears to have been recut) through $115,119,518$, $516,513,516,510,509$ and three unnumbered postholes, 287, 244, 195 and 242. The excavated features ranged in size between $0.25 \mathrm{~m}$ and $0.4 \mathrm{~m}$ in diameter, with depths ranging from $0.3 \mathrm{~m}$ to $0.5 \mathrm{~m}$. No occupation deposits were recovered from the interior of the structure. It is conceivable that this structure was in fact some form of windbreak or unroofed shelter surrounding the smithing hearth described above. A semi-circular windbreak might explain the apparent absence, noteworthy given the sizes of the other examples recovered, of post-holes in the western sector of the structure. A curving line of post-holes to the south, several of them double (eg 234, 236/239, 249/247, 229, 201, 291/293), could suggest the presence of yet another structure in this area, or possibly a lean-to for Structure H.

Other explanations for the lack of corresponding post-holes might include (a) the buildings were not finished, (b) the buildings only required deep foundations on one side or (c) they were built partly of another material that is now lost.

\subsection{Other structures}

To the east of Structures F and G are a number of post-holes which can be reconciled, in some instances at least, into putative structural patterns (Structures I-J). It is postulated that some of these post-holes may relate to a series of four-post structures measuring approximately $3 \mathrm{~m} \times 3 \mathrm{~m}$. Structure J could relate to a slightly curved postbuilt structure, with a length of approximately $12 \mathrm{~m}$, although it seems more likely to have formed a series of smaller, neighbouring structures. Small rectilinear settings of posts have previously been associated with storage, livestock holding pens and 
$\underset{100 / 130}{+}$

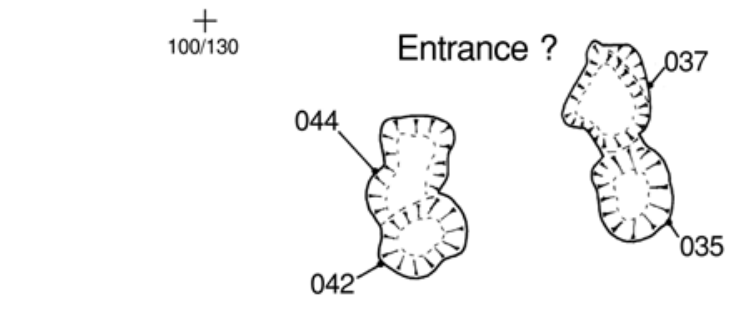

$\underset{100 / 136}{+}$
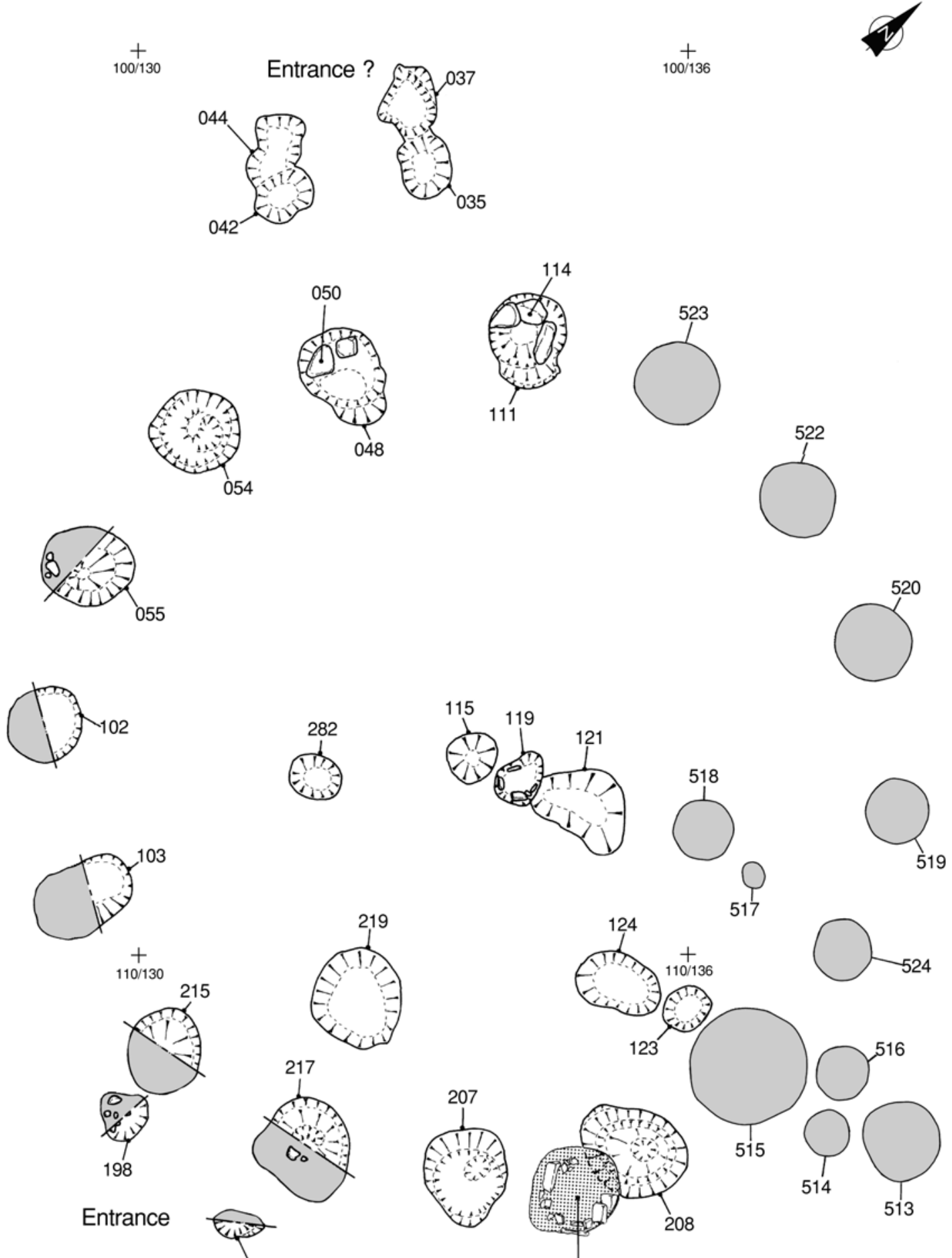

Entrance
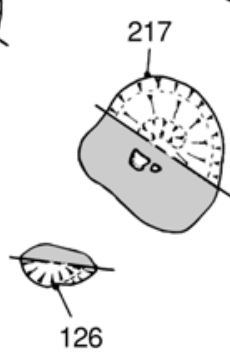

Hearth (127)

Unexcavated fill

0

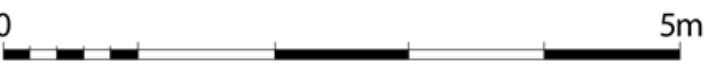

Illus 6 Structure G, post-hole arrangements 

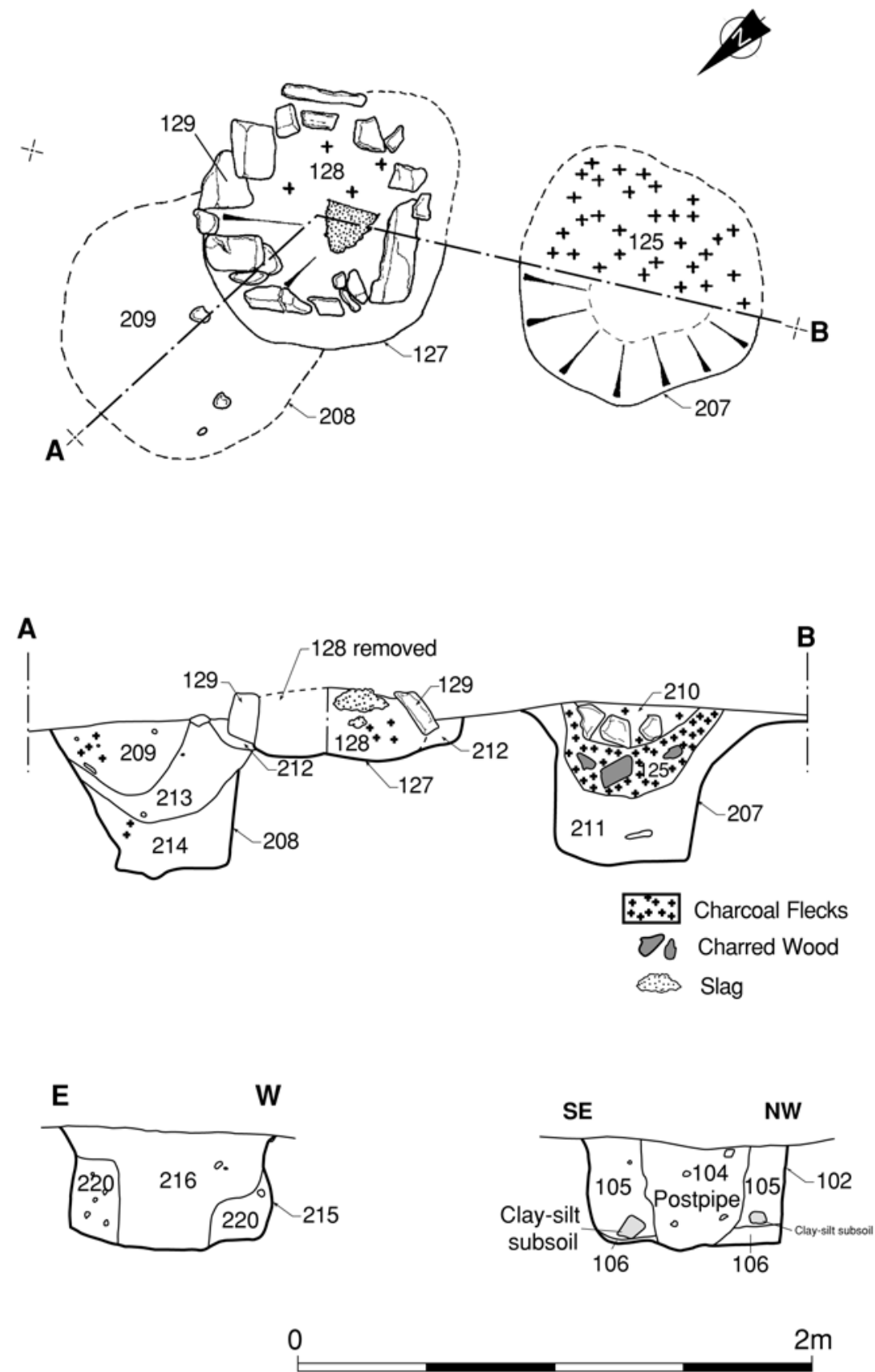

Illus 7 Section through hearth and adjoining post-hole in Structure G, and other post-holes of Structure G

other less prosaic functions (Ellison \& Drewett 1971). There are similarities between the Seafield structures and four- and six-post structures found elsewhere in the north-east of Scotland, for example at Douglasmuir, Angus (Kendrick 1995, fig. 24), at Ironshill, near Inverkeilor, Angus (Pollock 1997, fig. 16) and Houses 3 and 8 at Dryburn Bridge (Dunwell 2007). A line of post-holes may represent part of a stockade fence (represented by, from north-west to south-east, 521, 513, 508, 507, 505, 503, 502, 144, $276,338)$. Structure I could represent an entrance $c 7 \mathrm{~m}$ long through this fence, with holding pens set either side of it.

Whilst an interpretation related to livestock control seems reasonable, it should be noted that several of the excavated post-holes in this area were very deep (up to $0.75 \mathrm{~m}$ ), post-hole 175 in particular (illus 8) but also 181, 182 and 184. This latter contained a glass bead (dated 1st century BC to 2 nd century AD, see Section 4.3.3), a base sherd of undated pottery and a small quantity of slag and vitrified hearth lining. Nearby feature 181 also produced slag and hearth lining fragments, and a small quantity of burnt bone. It is unclear how these objects would have been deposited in an area used entirely for stock management, and it may be that another roundhouse was located here at some point. Curving lines of post-holes can be discerned amongst the general background scatter. 
(a)

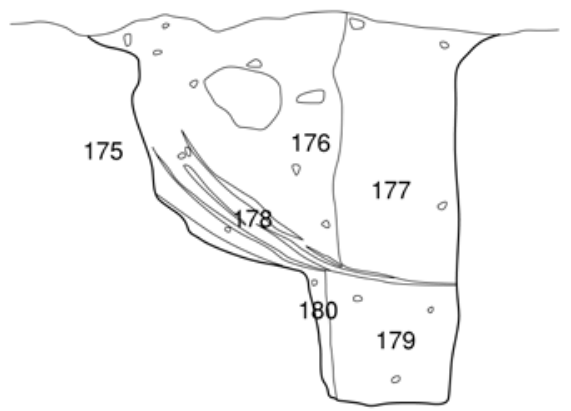

(b)

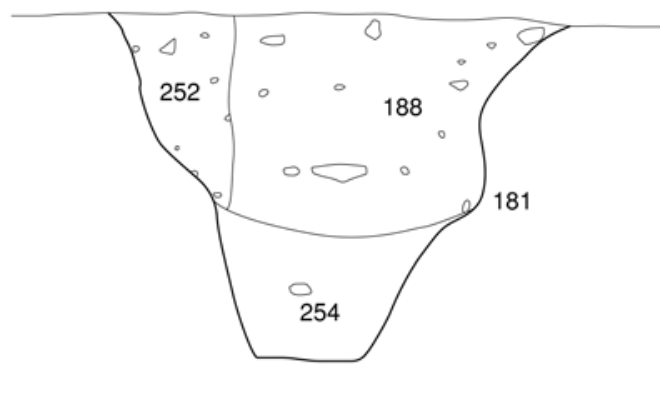

0 0.5 $1 \mathrm{~m}$

Illus 8 Sections of post-holes associated with Structure I 


\section{THE FINDS}

The following reports are in some cases abridged versions of more comprehensive reports which include tables of numerical data. All this additional data will be accessible in the site archive deposited with RCAHMS.

\subsection{Prehistoric pottery, by Melanie Johnson}

Four sherds of handmade prehistoric pottery were recovered, weighing $29 \mathrm{~g}$ in total. Three of the sherds are rims and one is a fragment of a base. The minimum number of vessels is three, as two of the rim sherds join.

Rim sherd 1 (fill of post-hole 069 in Structure F; illus $9 \mathrm{a}$ ) is thick and coarse with a flattened top and would be a simple bucket- or barrel-shaped vessel. The fabric is generally coarse, with inclusions of sub-angular grits of granite measuring up to $13 \mathrm{~mm}$, quartz, mica and other small stones, all of which are locally available or would have been present already within the clay.

Rim sherd 2 (occupation layer 034 in Structure C; illus $9 \mathrm{~b}$ ) comprises two joining pieces of a fine, wellfired vessel with an everted rim and containing tiny mica flakes. The rim is very small and the vessel's profile cannot be reconstructed. These sherds have a small amount of charred organic residue adhering to their outer surface, indicating that the vessel was used for cooking.

It is difficult to suggest a date for these sherds; however, their form and fabric compare well with so-called 'flat-rimmed ware', a body of currently poorly-defined wares of the Mid to Late Bronze Age and Iron Age, found across much of mainland Scotland; vessels which could belong to the
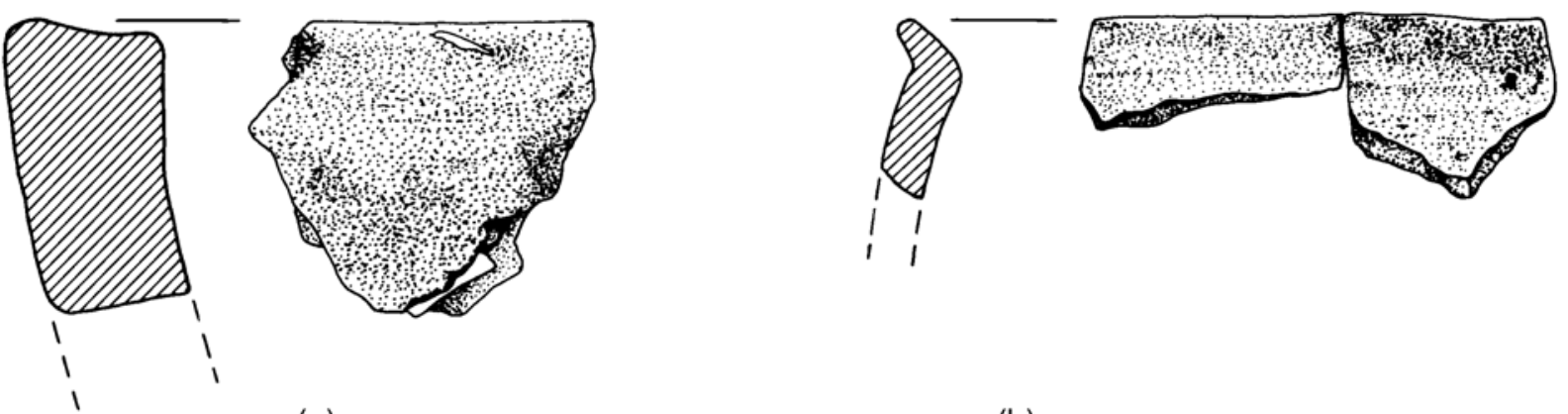

(a) 'flat-rimmed ware' tradition are found throughout Scotland on a range of domestic sites. Good comparisons for this rim sherd can be found, for example, at Deer's Den, Kintore, Aberdeenshire (Alexander 2000) where ring-ditch houses have been dated to the Mid and Late Bronze Age (spanning 1600-700 BC), and Wardend of Durris, Aberdeenshire (Russell-White 1995), dated to between $400 \mathrm{BC}$ and $\mathrm{AD} 260$.

It is impossible to suggest a date for a flat base sherd from post-hole 175 ('Structure I'), or to say anything meaningful about the vessel's form.

There is no evidence for any organic temper in any of the sherds, and the surfaces of the vessels may have originally been wet-smoothed. The assemblage has suffered a high degree of abrasion. A full catalogue of the pottery is lodged in the site archive.

\subsection{Coarse stone artefacts, by Ann Clarke}

There are four stone artefacts from the site including two unfinished rotary querns (illus 10a and b), a whetstone (illus 10c) and a large battered hammerstone (illus 10d). The whetstone is made on a pebble with the shape formed by the two smoothlyworn, skewed faces. The upper rotary quern stone (10a) has an unfinished central perforation and the base is completely unworn but there appears to be no physical reason, eg breakage, why this stone was not finished for use as a quern. A sub-circular slab (illus 10b) is similar to 10a but apart from the rough outline shaping there is no other evidence that it was worked and it may be a blank for a rotary quern.

All the pieces are standard late Iron Age (or later) artefacts. The whetstone was found in the fill of the

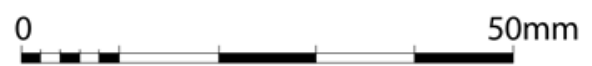

Illus 9 Pottery: a) post-hole 069, Structure F; b) layer 034, Structure C 

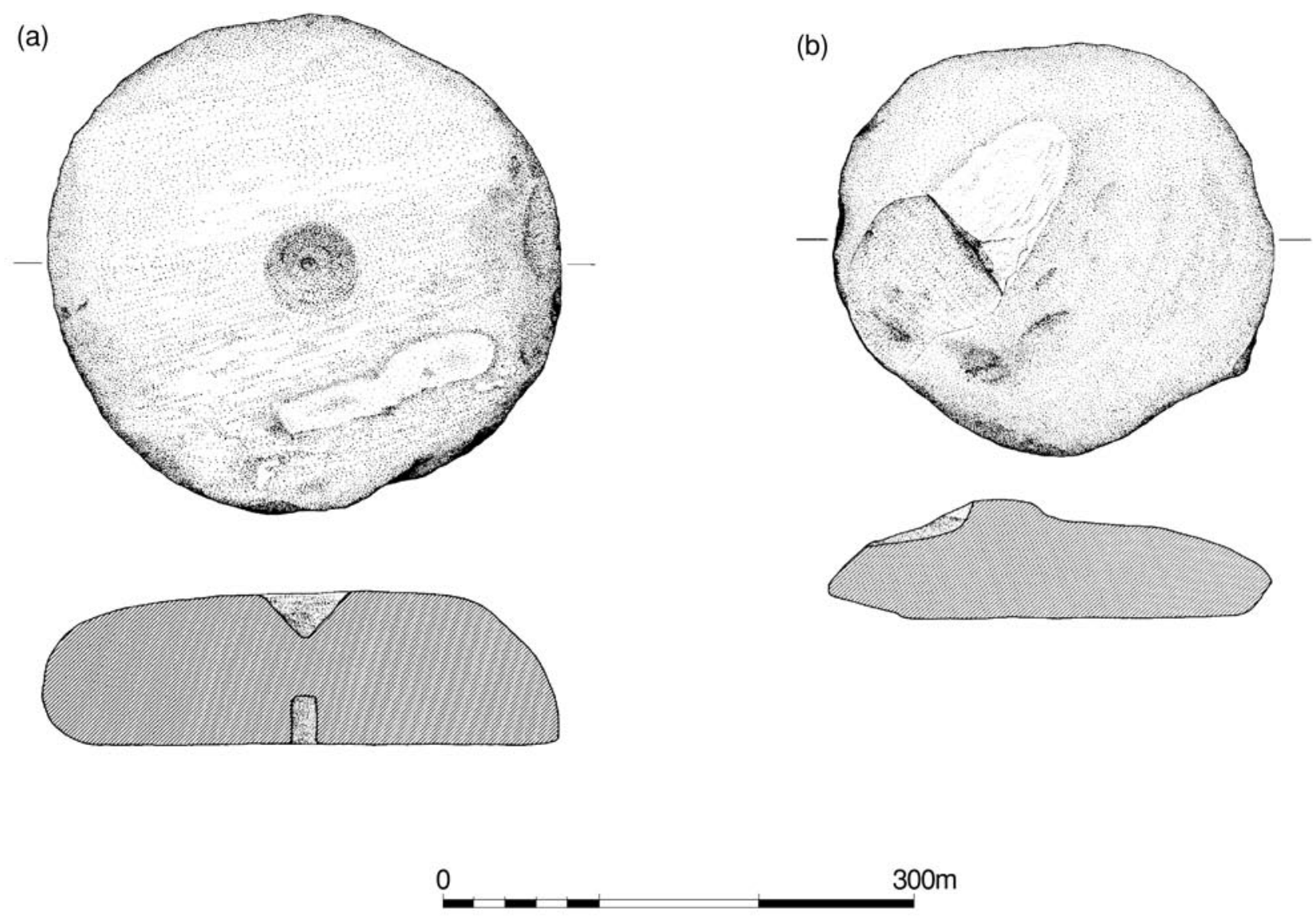

(c)

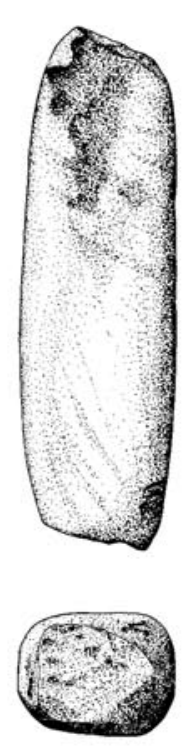

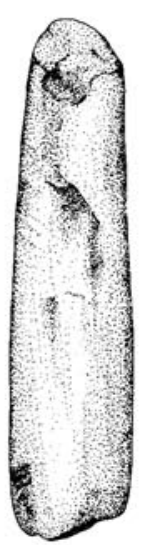

(d)
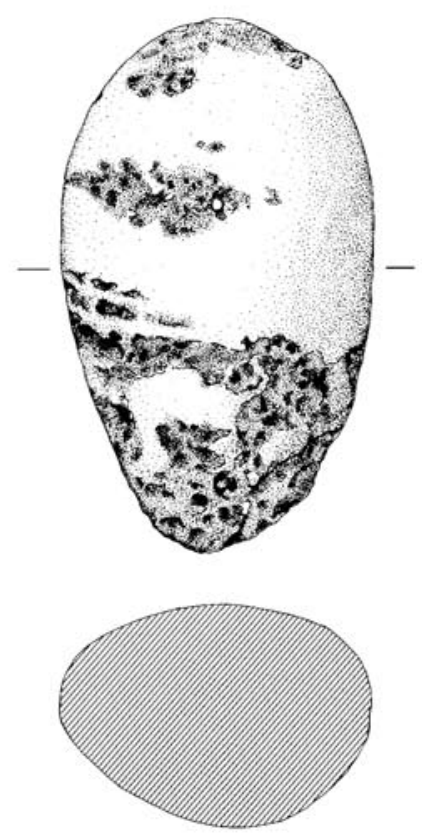

$100 \mathrm{~mm}$

Illus 10 Coarse stone objects: a) \& d) layer 033, Structure B; b) post-hole 084, Structure F; c) ditch 004, Structure B 
palisade ditch in Structure B, close to the entrance. The upper rotary quern and the large hammerstone were found in the demolition layer (033) associated with Structure B. The other rotary quern blank was recovered from a post-pit feature (084) in Structure F. The quernstones may have been reused as structural elements, eg as post-pads, but it is possible that the placement of one in the post-pit was a deliberate act of ritual. It is becoming increasingly clear that the deposition of quernstones, which are most commonly found redeposited in structural contexts on Iron Age sites, is more than a simple act of reuse of a suitably shaped building stone. Hingley has noted the instances of quernstones in boundary contexts of hill forts and in late Iron Age cist burials (Hingley 1992, 32, 38). On settlement sites it is not unusual to find querns incorporated into walls or floors: a rotary quern found in the primary paving of the floor from the broch at Fairy Knowe (Clarke 1998) and single querns found in the fill of a pit and in the paving both associated with the entrance to the structure at Cnip, Lewis (Clarke 2007) are recent examples. Such deposits are clearly invested with deeper meanings for community and landscape and may be compared with the inclusion of grain and tools of tillage in the walls of earlier prehistoric houses in Shetland and in burial mounds in the Northern Isles (Clarke 1996).

\subsection{Metal and glass objects, by Fraser Hunter}

\subsubsection{Copper alloy dolphin-type brooch from Structure B (illus 11a)}

Polden Hill brooch with Dolphin profile. Most of the pin is lost and there is some damage to the footplate and bow. The 8-turn spring with broken internal chord is held by an iron axis through the closed ends of the spring cover - the characteristic Polden Hill fastening mechanism - although an internal rather than external chord is unusual, rendering non-functional the hook on the head which would normally retain it. The head is humped over the spring in the Dolphin style, with low curved mouldings on the sides. The bow is plano-convex in section, decorated with a central recessed spine running its length which contains a poorly formed zig-zag design created by V-shaped incisions along one side of the channel. It terminates in an expanded conical foot knob with a ridged collar. The catchplate meets the bow in a long, concave curve. L $82 \mathrm{~mm}$; W 23mm; H 20mm. Alloy: both bow and spring are leaded bronze (by non-destructive $\mathrm{X}$-ray fluorescence).

There is some confusion over such brooches in the literature. Mackreth (1996a, 300-1) classes them in the broad category of Colchester Derivative with individual discussion as required, but this is a very diverse group and more refinement is required. The defining characteristic of Polden Hill brooches is the unusual pin fastening as defined above, but there is debate over whether this should refer to a brooch type or just a specific fastening method used on a variety of brooches (Hattatt 1985, 82). The most useful discussion is by Webster (1981, 169-71; 1995, 74-82), who distinguishes several different Polden Hill types based on the bow form; this is an example of her Polden Hill with Dolphin profile. The debate is largely terminological: the type is intimately related to Dolphin brooches (characterised by a bow humped over the spring), but with a Polden Hill spring fitting. Such brooches are rare in Scotland; considering Dolphins and Polden Hills together, the writer knows of parallels from only three Roman sites: Newstead (eg Curle 1911, pl LXXXV, 5); Milton (unpublished; Dumfries Museum); and Birrens (unpublished; Dumfries Museum 1984.27.75). From non-Roman contexts, there are only three others: a Dolphin brooch from Whitekirk, East Lothian (Robertson 1970, table V), a very fine Polden Hill with Dolphin profile from Polmaise, Stirlingshire (Callander 1918), and another from Berscar, Dumfriesshire (unpublished; Dumfries Museum 1990.49.1). The date range of the type is $c$ 60-150/175 AD (Webster 1995, 74; Mackreth 1996a, 301). The distribution is primarily southern (ibid), although with a northward spread (eg Snape 1993, 9-14).

The brooch was found in a trial section across the palisade trench 004 of Structure B2. This opens up the possibility that it may have been a deliberate deposit, perhaps as a foundation deposit at the house boundary. The use of Roman brooches in this way can be paralleled at Carronbridge, Dumfriesshire, where an unusual trumpet brooch came from the upper fills of the terminal of a penannular ditch round a house (Johnston 1994, 250); Roman brooches are also found in other ritual contexts (eg Lamberton Moor, Berwickshire (Anderson 1905); Inchyra, Perthshire (Hunter 1996, 117-8)). As only a few sections of the palisade were excavated, it is impossible to assess whether this was a unique deposit or part of a pattern.

\subsubsection{Copper-alloy headstud brooch from Structure C (illus 11b)}

Enamelled headstud brooch (Collingwood \& Richmond (1969, 296) group Q), broken into four main fragments (see A, B, C and D below) and innumerable flakes, found in Structure C layer 034. The four fragments include the following elements:
A) Headstud and part of bow.
The headstud is an integral part of the casting, com- prising an outer ring and a raised centre; it is unclear if enamelling was ever present in the channel between the two. The bow is hollowed on the underside. Nothing survives of the wings or the fastening mechanism. Below the headstud the bow bears a rectangular strip enamelled in two colours. The champlevé design comprises a row of central blue lozenges surrounded by cells of red triangles (now highly discoloured). L $19 \mathrm{~mm}$; W $8.5 \mathrm{~mm}$; T $7.5 \mathrm{~mm}$. 
(a)

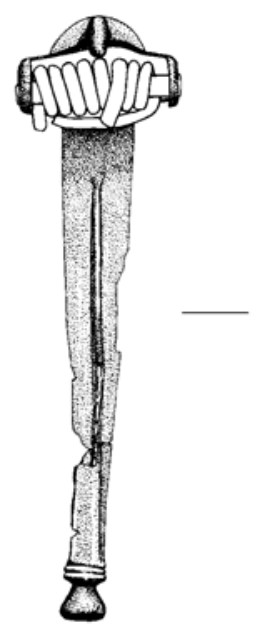

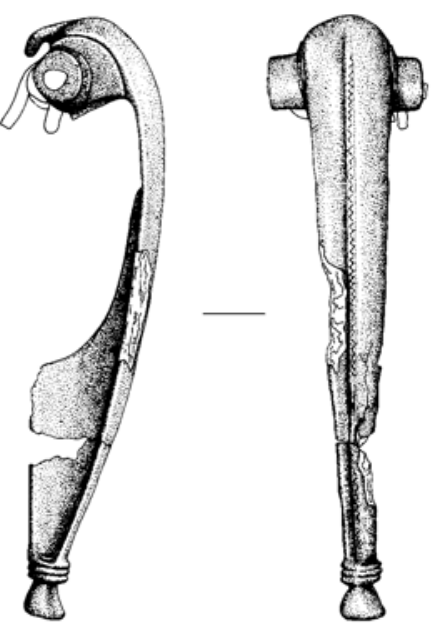

(b)
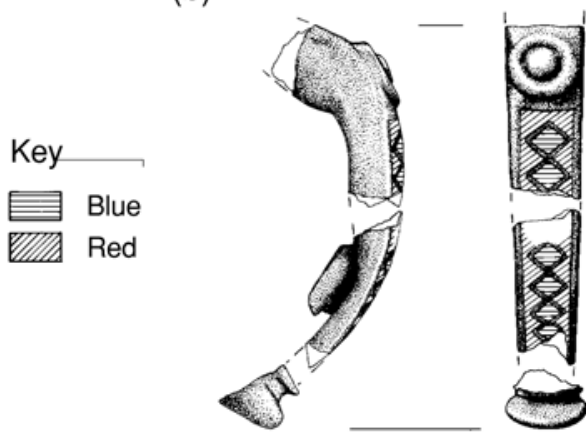

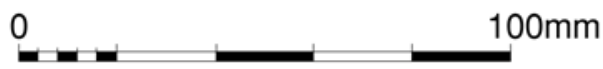

(c)

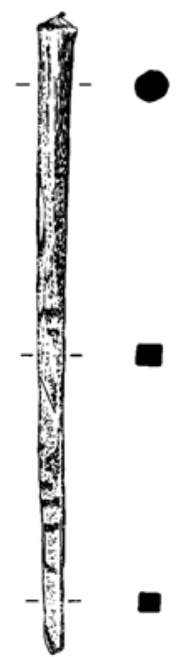

(d)

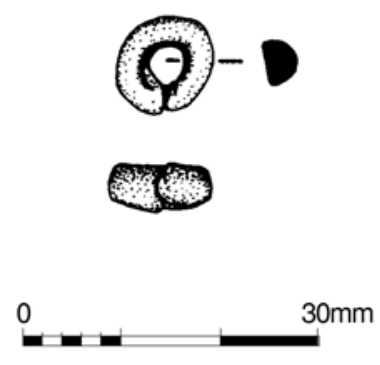

Illus 11 Metal finds: a) ditch 004, Structure B; b) layer 034, Structure C; c) pit 431, near Structure D; d) pit 152, east of Structure D

B) Enamelled bow fragment, continuing the lozenge and triangle design of (a).

The bow tapers slightly along its length, and probably joined directly to (a), but the ends are now too corroded for certainty. A curved rod fragment, sub-rectangular in section, is corroded to the underside, and is probably part of the pin. L $18 \mathrm{~mm}$; W $8.5 \mathrm{~mm}$; T $4 \mathrm{~mm} 5.5 \mathrm{~mm}$ with pin.

C) Expanded circular footknob fragment, $9 \mathrm{~mm}$ in diameter, demarcated from the bow by a collar and channel.

The collar bears corrugated decoration. L 6.5mm; W 9mm; T $6 \mathrm{~mm}$ (incomplete).

D) ?Arm fragment, with a slight step on its vertical edge. The fragment is too small to be certain of the identification. L $8 \mathrm{~mm}$; W $6 \mathrm{~mm} ; \mathrm{T} 4.5 \mathrm{~mm}$.
The overall dimensions of the brooch provide a minimum length of $45 \mathrm{~mm}$. The bow is gunmetal. Analysis of the enamels was not possible due to their small size, decayed nature and interference from the metal substrate.

Headstud brooches are the second commonest Roman brooch type found on native sites; it has been argued elsewhere that this is due to their similarity to local decorative habits, given the presence of enamelling on most specimens (Hunter 1996, 122-3, fig. 6). The enamelled headstud was fully developed as a type by the time of the Agricolan invasions, and continued throughout the 2nd century AD (Snape 1993, 14-15). 


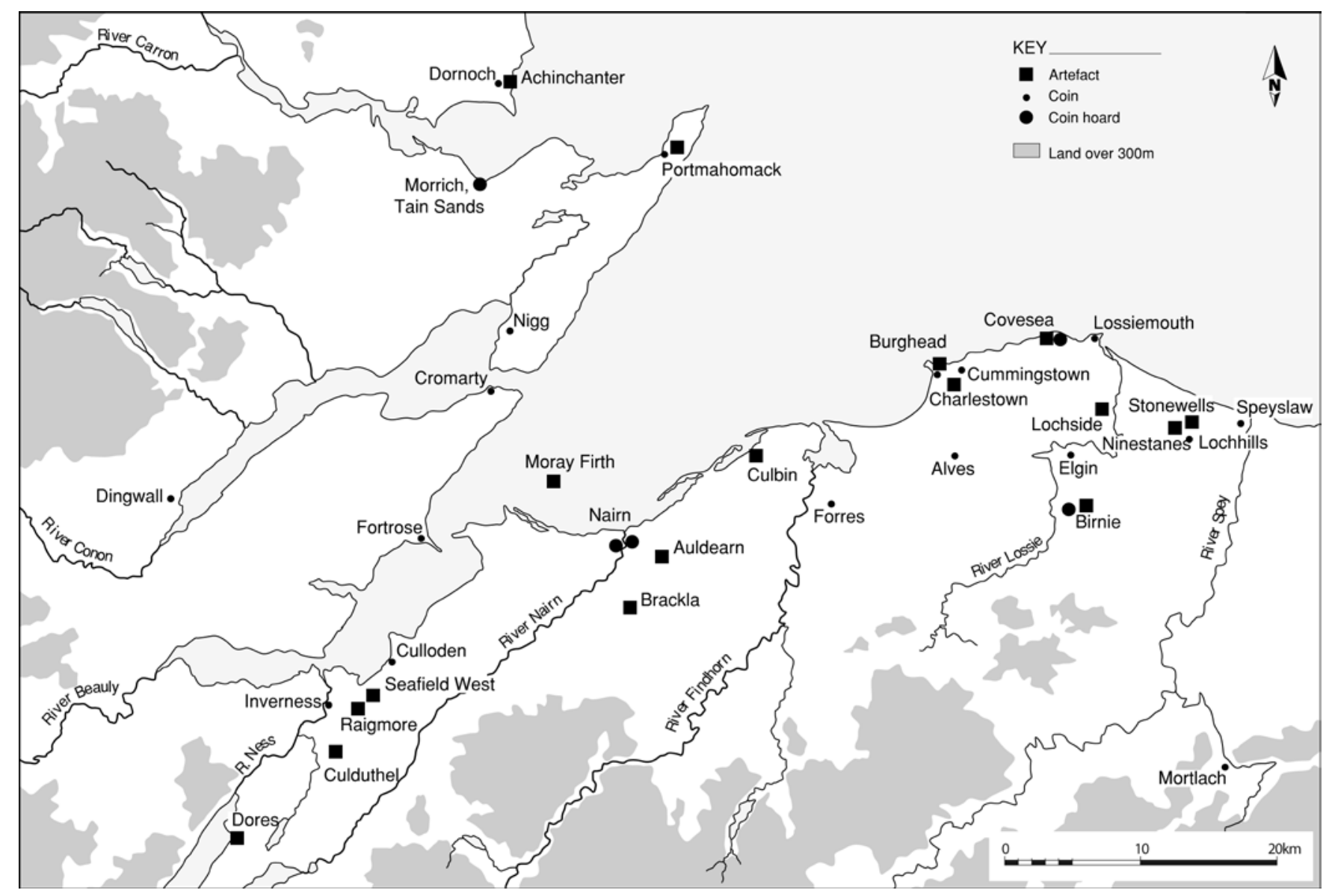

Illus 12 Distribution of Roman finds within the Moray Firth region

\subsubsection{Miscellananeous small finds}

Structure B2: Fragment of gilt sheet copper alloy. Distorted, with no original edges. Medieval or later. 10.5 $\times 6.5 \times 0.2 \mathrm{~mm}$. Context 010, clean-up layer of machinedisturbed charcoal-rich soil, remnant of the occupation layer (033) over the southern half of the structure.

Post-hole 175 in Structure I: Fragment of a glass bead of Guido (1978, 87-9) class 14.

Deep blue body with inlaid yellow blob and an inlaid spirally twisted cable of opaque white and pale blue. The broken face preserves a trace of a yellow inlaid blob. Original dimensions uncertain - no trace of the perforation survives. $10 \times 7.5 \times 7.5 \mathrm{~mm}$. This find fits easily in the distribution of this bead type (Guido 1978, fig. 36), which indicates it is a product of north-east Scotland (see also Henderson 1989, 69-71). Recent stratified finds and scientific analysis of the glass used has expanded the likely date range from Guido's more precise estimate to 1st century BC-2nd century AD (Henderson 1994).

\section{Pit 431: Iron tool (illus 11c)}

The tang is square-sectioned, changing to oval just above mid-section; the working end is broken off, preventing identification. L $130 \mathrm{~mm}$; tang section $6.5 \times 6.5 \mathrm{~mm}$; shaft section $8 \times 6.5 \mathrm{~mm}$.

Pit 152: Located east of Structure D: Lead bead (illus 11d; recovered during wet sieving).

Formed from a D-sectioned strip bent into a circle, with one end slightly doubled under. External diameter $10 \times$ 9mm; internal diameter 3-3.5mm; T 4.5mm. Context 149, upper fill of pit 152. Although this pit is undated, in the site context it is likely to be Iron Age. Lead is unusual in the Scottish Iron Age: while there are some pre-Roman finds, its use in any quantity starts with the availability of Roman lead as a raw material (Hunter 1998, 355-6). Rings of this size are most likely to have been used as beads: compare an example from Traprain Law (Curle \& Cree 1921, 198, fig. 24.25). However, note that there was modern material in several of the surrounding features.

Structure B2: Fe lump.

Badly corroded and fragmented. Either a corrosion blister or a possible nail. Fill 351 of palisade trench 004. Not subjected to X-ray analysis as considered too friable.

Structure B2: Fe strip or bar.

Fill of post-hole 368 .

\subsubsection{Discussion of Roman finds distribution}

Recent finds of Roman objects from the Moray Firth area have markedly expanded the picture of Roman contact in the area (illus 12 and Appendix 1); compare maps in Robertson (1970). Most sites have produced only one or two finds, but some richer sites are known, such as the settlement site of Birnie, or the ritual site of the Sculptor's Cave, Covesea (Benton 1931; Hunter 2007). The brooches are likely to have been valued as some form of status good (see Macinnes 1984, 241-5; Hunter 2001; Hunter 2007).

Roman objects in native society are generally 
interpreted as status goods (Macinnes 1984, 2415 ). With the richer southern sites it is argued that contact with the Romans was controlled through chiefs, who acquired a wide range of material and passed smaller quantities on to clients, dependants or fellow chiefs. It is likely that such exotica were similarly valued in the north, and although the site assemblages are not particularly rich, two broad patterns may be noted in the distribution. A concentration of finds on the southern rather than the northern shore of the Moray Firth may arise from the better arable land, which would have made the inhabitants wealthier and therefore better able to acquire Roman goods, as well as a target for Roman diplomatic efforts and gifts. Secondly, there are hints of a cluster in the Burghead/Lossiemouth/Elgin area, which emerged as the heartland of Pictish Moray in later centuries (Shepherd 1993). This suggests that access to Roman material may have been focused on a power centre, which fits the model of elite social control over access to such exotica.

In sum, the presence of these two Roman brooches, one of them unusual in Scottish terms, suggests that the inhabitants of the Seafield West site were of some status.

\subsection{Ironworking debris, by Andrew Heald, Gerry McDonnell and Ian Mack}

A total of $8.7 \mathrm{~kg}$ of slag was recovered. The majority of the debris is associated with ironworking, probably smithing. Although much of the slag was found in secondary contexts, such as ditch fills and post-holes, the majority was associated with the hearth feature (127) in Structure H. This is one of the few in situ dated ironworking features from Iron Age Scotland.

\subsubsection{The ironworking process}

The production of bloomery iron is essentially a four-stage operation: ore roasting; smelting (the extraction of the metal from its ore); bloomsmithing (working the iron bloom to remove further waste products (gangue)); and finally blacksmithing (the production of artefacts and their subsequent repair). The identification of these stages relies on the survival and recognition of the structures and tools used and the residues formed during the smelting and smithing processes. Of prime importance is the recovery and identification of the residues derived from each process.

\subsubsection{The residues}

Identification was based on the morphological study of the internal and external areas of the object, analysis of weight, density, colour, streak, texture, porosity and inclusions (after Bachmann 1982; McDonnell 1986). Scientific analysis was under- taken on representative pieces. General descriptions of the slag groups are given below and summarised by context in Table 1 and listed in Appendix 2 .

Six fragments, totalling $380 \mathrm{~g}$, of hearth lining (HL) were recovered. While this material cannot be related specifically to ironworking, the contextual associations with other smithing material (Table 1) suggest that some of the material derives from the same process.

One piece of runned slag (RS) was found in the entrance gully of Structure B trench (fill 096), weight $122 \mathrm{~g}$. This has the appearance of tapped slag, the molten waste product from smelting. This slag runs off into bar-shaped channels where it solidifies, which gives it a characteristic dense, black, ropey appearance.

Seven plano-convex slag cakes (many fragmentary) were found, totalling 4923g. The outer surfaces were normally nodular in texture, with evidence of charcoal impressions. Many have areas of red oxide powder indicating active corrosion of an iron-rich zone. The slags come in a range of sizes. It is often difficult to be sure whether such cakes were produced during smelting or smithing; criteria are usually based on dimension and weight (eg McDonnell 1994, 230; 2000, 219). However, such differentiation of the Seafield assemblage is difficult as many cakes appear to be amalgams. The surviving cakes vary in size with the average dimensions: weight: $584 \mathrm{~g}$, maximum diameter $83 \mathrm{~mm}$, depth $40 \mathrm{~mm}$. That said, it is likely that the majority are smithing hearth bottoms (SHB), accumulations of slag that developed in the smithing hearth and were removed when they became too large and interfered with the efficiency of the hearth. This is supported by scientific analysis of one of the larger amalgams (see below).

Nine collections of fragmentary slag were found, weighing a total of $3027 \mathrm{~g}$. General characteristics, and the association with other smithing debris of some of the pieces, suggest that the material is best described as smithing slag (Smi).

Minute amounts of slag spheres (SS; $2 \mathrm{~g}$ ) and hammerscale (HS; 1g) were found, all in soil sample residues. These are surface-oxidised iron expelled during hammering and/or when reheated in the hearth. Slag spheres are ejected as spherical globules of molten slag, while hammerscale resembles flaked iron plates. Most pieces were dispersed within minute globules of other vitrified slag or fused silica. When found in large quantities, these slags are normally indicative of in situ working.

In total $256 \mathrm{~g}$ of unclassified slags (Unc) were found. This group contains all the fragments that do not have sufficient of their external surfaces to place them in any of the above classes. Commonly, this is the slag that develops in the smithing or smelting process but is raked out before forming a hearth bottom. It is typical for unclassified slags to constitute between $20 \%$ and $50 \%$ of the total site assemblage. 
Table 1 Slag by type and provenence

\begin{tabular}{|c|c|c|c|c|c|c|c|c|}
\hline & SHB & Smi & HS & SS & Un & $\mathbf{R S}$ & HL & Total \\
\hline \multicolumn{9}{|l|}{ Structure B1 } \\
\hline 412 fill of post-hole 411 & - & 53 & - & - & - & - & 102 & 155 \\
\hline \multicolumn{9}{|l|}{ Structure B2 } \\
\hline 005 fill of slot 004 & 589 & 385 & - & - & - & - & - & 974 \\
\hline 096 fill of slot 004 & 272 & - & - & - & - & 122 & - & 394 \\
\hline 097 fill of slot 004 & - & - & - & - & 11 & - & - & 11 \\
\hline 363 fill of post-hole 364 & - & - & - & - & - & - & 36 & 36 \\
\hline 367 fill of pit 368 & - & 178 & - & - & - & - & - & 178 \\
\hline \multicolumn{9}{|l|}{ Structure C } \\
\hline 034 occupation layer & - & - & - & - & 3 & - & - & 3 \\
\hline 153 fill of pit 154 & - & - & - & - & 6 & - & - & 6 \\
\hline 161 soil layer & - & 31 & - & - & - & - & - & 31 \\
\hline \multicolumn{9}{|l|}{ Structure F } \\
\hline 062 fill of post-hole 061 & - & - & - & - & 9 & - & - & 9 \\
\hline \multicolumn{9}{|l|}{ Structure G } \\
\hline 057 fill of post-hole 054 & - & 107 & - & - & - & - & - & 107 \\
\hline 060 fill of post-hole 055 & 92 & - & - & - & & - & - & 92 \\
\hline 209 fill of post-hole 208 & - & - & - & - & 2 & - & - & 2 \\
\hline \multicolumn{9}{|l|}{ Structure H } \\
\hline 128 fill of hearth 127 & 3761 & 1920 & 1 & 2 & - & - & 53 & 5737 \\
\hline 285 fill of hearth 124 & - & - & - & - & 5 & - & - & 5 \\
\hline 117 fill of post-hole 115 & - & - & - & - & 43 & - & - & 43 \\
\hline \multicolumn{9}{|l|}{ Structure I area } \\
\hline 176 fill of post-hole 175 & - & - & - & - & 6 & - & 48 & 54 \\
\hline 179 fill of post-hole 181 & 209 & - & - & - & - & - & - & 209 \\
\hline 180 fill of post-hole 181 & - & - & - & - & - & - & 42 & 42 \\
\hline 188 post-pipe in 181 & - & 108 & - & - & - & - & 99 & 207 \\
\hline \multicolumn{9}{|l|}{ Non-structural } \\
\hline 025 fill of 026 near Str A & - & - & - & - & 1 & - & - & 1 \\
\hline 093 fill of 094 near Str A & - & - & - & - & 3 & - & - & 3 \\
\hline 156 fill of pit 155 & - & 128 & - & - & - & - & - & 128 \\
\hline Unstratified & - & 117 & - & - & 163 & - & - & 280 \\
\hline Total & 4923 & 3027 & 1 & 2 & 252 & 122 & 380 & 8707 \\
\hline
\end{tabular}

SHB= Smithing hearth bottoms; Smi = Smithing slag; HS = Hammerscale; SS = Slag spheres; Un= unclassified slag; RS = Runned slag; $\mathrm{HL}=$ Hearth lining.

\subsubsection{Scientific analysis}

As many plano-convex slags could not be ascribed to smelting or smithing on the basis of external characteristics alone, and as very little information exists on Iron Age slags in Scotland, a representative example (Cat 014) was subjected to scientific analysis in the Conservation and Analytical Research section in the Department of Archaeological Sciences, University of Bradford by Mack and McDonnell.

The weight of the largest plano-convex slag, over
2000 g, suggested a high-density smelting slag. In order to determine whether the slag was derived from iron smithing or smelting a complete section was taken through the centre of the slag. This seemed to be fairly heterogeneous so three small transverse sections were taken to sample all areas of apparently different compositions. These three samples were mounted and polished using abrasive papers and diamond pastes, and analysed using optical light microscopy and scanning electron microscopy (SEM), with additional digital image 


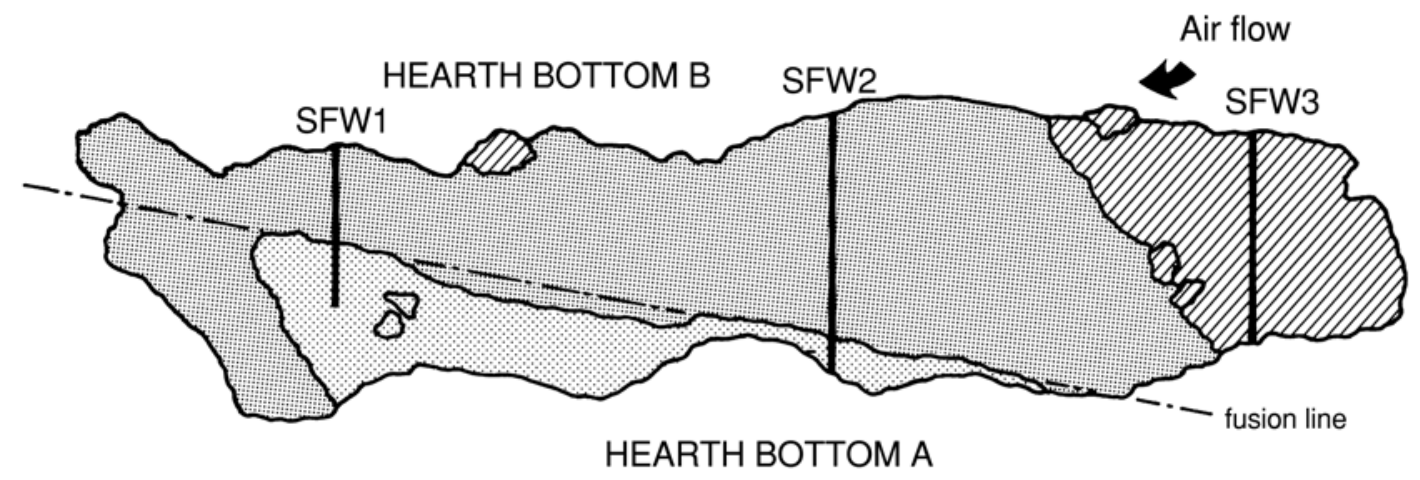

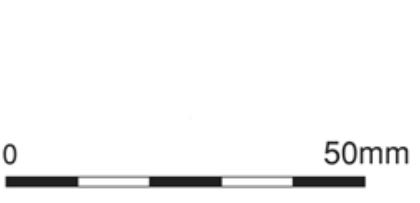

Illus 13 Analytical section through hearth slag

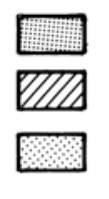

Dense black slag
Glassy black slag

Porous slag with red oxide layer

SFW1-3 indicate section positions processing and analysis. Illus 13 shows the section positions through the centre of slag and reconstruction of hearth bottom formation.

Indicated by the thick black lines are the areas sectioned for micro-structural and chemical analysis (samples SFW1, SFW2 and SFW3 in illus 13). There were three recognisable zones of slag. Whilst much was fairly dense, the base of the slag contained a zone of high porosity with an abundance of red oxide powder indicating active corrosion of an iron-rich zone, and near one edge a zone of slightly glassier material could be seen. The three sections were positioned to sample these distinctive areas. Other noticeable features were that numerous charcoal impressions were spread throughout the slag, particularly near the base, whilst the top surface contained a few large silica grains $(<10 \mu \mathrm{m})$.

Under optical light microscopy all three sections appeared similarly composed of massive iron silicates with a small amount of a blocky phase likely to be hercynite. Free iron oxide existed as dendritic wustite, with all of the above present within a glassy matrix. The most noticeable difference between the three sections was that the amount of wustite was visibly less in SFW3 (5\%) than in the other two sections (both 24\%) and seemed to equate with the 'glassier' macroscopic qualities of this region. The specific amount of dendritic wustite was calculated using phase discriminative image analysis and the results corresponded well with the impression that this section contained less free iron oxide ( $\mathrm{FeO})$.

Samples SFW1 and SFW3 were also quantitatively analysed by SEM to determine specific chemical components. Bulk area analysis using raster scans at $\times 500$ and targeted spot analysis were used to provide general compositional information and analyse specific phases. From the bulk analyses it is clear that the sections differ mainly in the ratio of iron silicates to free iron oxide, SFW1 having about 25:60 and SFW3 30:60. This may explain why SFW1 appeared 'glassier' and could be seen to contain less $\mathrm{FeO}$ as dendritic wustite. The dendritic wustite analysed predictably contained over $96 \% \mathrm{FeO}$, whilst in contrast the 'blocky' hercynite phase contained aluminium oxides as well as silica and potash.

The ratios of iron silicates to free iron oxides noted may be expected in both smelting and smithing slag. The levels of manganese, however, suggest that this slag is more likely to derive from smithing as levels in excess of $1 \%$ would be more likely in a smelting slag. A smithing origin also explains the presence of metal prills and silica grains, which are commonly found in smithing slags, and may also explain the production of discrete areas of morphological and chemical difference in the slag. Illus 13 shows the proposed reconstruction of the formation of the slag, which may be as a hearth bottom that has been fused or has agglomerated to an existing hearth bottom in the forge hearth. The tuyère position and proposed airflow were suggested by the position of the two major zones and the surface morphology. Hearth bottom A was deposited in the hearth first and hearth bottom B was formed during a second distinct use of the hearth.

Based on the micro-structural and chemical analyses (Table 2) it seems likely that this slag is a hearth bottom derived from blacksmithing processes. Furthermore it is likely that this has been formed by the fusion of two hearth bottoms, indicating two distinct smithing events.

\subsubsection{Slag distribution}

The slag distribution can be divided into two groups: slag from secondary contexts, such as post-holes 
Table 2 Quantitative chemical analyses by SEM (normalised to 100\%)

\begin{tabular}{llcrrrrrrrrrrr}
\hline Sample & Scan & $\mathbf{N a}_{\mathbf{2}} \mathbf{O}$ & $\mathbf{M g O}$ & $\mathbf{A l}_{2} \mathbf{O}_{3}$ & $\mathbf{S i O}_{2}$ & \multicolumn{1}{c}{$\mathbf{P}$} & \multicolumn{1}{|c}{$\mathbf{K}$} & $\mathbf{C a O}$ & $\mathbf{T i O}$ & $\mathbf{M n O}$ & $\mathbf{F e O}$ & $\mathbf{C o O}$ & $\mathbf{C u O}$ \\
\hline SFW1 & Bulk 1 & 1.5 & 1.1 & 4.4 & 23.5 & 0.4 & 1.3 & 2.1 & 0.2 & 0.5 & 64.7 & 0.2 & 0.1 \\
& Bulk 2 & 3.6 & 0.9 & 8.1 & 25.3 & 0.8 & 2.9 & 4.6 & 0.2 & 0.4 & 53.0 & 0.1 & 0.2 \\
& Bulk 3 & 1.9 & 0.9 & 6.2 & 24.0 & 0.3 & 1.3 & 2.1 & 0.3 & 0.7 & 62.2 & 0.0 & 0.1 \\
& Silicate & 0.0 & 1.0 & 0.4 & 31.0 & 0.0 & 0.0 & 0.8 & 0.1 & 0.9 & 65.3 & 0.2 & 0.3 \\
& Glassy & 4.9 & 0.4 & 12.7 & 38.9 & 2.0 & 7.8 & 12.0 & 0.2 & 0.3 & 20.6 & 0.1 & 0.2 \\
& FeO & 0.9 & 0.1 & 0.5 & 0.6 & 0.0 & 0.3 & 0.2 & 0.5 & 0.3 & 96.4 & 0.0 & 0.4 \\
SFW3 & Bulk 1 & 3.9 & 0.6 & 11.4 & 31.1 & 1.3 & 4.7 & 4.0 & 0.6 & 0.4 & 39.4 & 0.0 & 2.7 \\
& Bulk 2 & 0.7 & 1.1 & 5.6 & 29.2 & 0.5 & 1.8 & 1.8 & 0.2 & 0.5 & 58.6 & 0.0 & 0.0 \\
& Bulk 3 & 1.6 & 1.4 & 6.6 & 30.4 & 0.0 & 1.8 & 2.2 & 0.3 & 1.1 & 54.3 & 0.3 & 0.1 \\
& Silicate & 0.7 & 0.3 & 0.5 & 30.8 & 0.0 & 0.2 & 2.2 & 0.0 & 0.6 & 64.6 & 0.0 & 0.2 \\
& Glassy & 2.0 & 1.2 & 18.0 & 54.3 & 0.4 & 19.8 & 0.9 & 0.4 & 0.0 & 2.1 & 0.8 & 0.1 \\
& Hercynite & 4.0 & 0.9 & 30.6 & 10.7 & 1.1 & 0.7 & 3.9 & 1.3 & 0.2 & 46.0 & 0.4 & 0.2 \\
\hline
\end{tabular}

and pits, and slag from apparently in situ contexts (Table 1).

As with many sites, a significant proportion of the Seafield West material derives from secondary contexts, particularly fills of pits and post-holes. Such associations are fairly common. Excavations at Bannockburn, Stirlingshire produced slag from the ring-groove and the outer post ring of house 1 (dated to around the 6th/5th centuries $\mathrm{BC}$ ) and other miscellaneous pits (Rideout 1996, 226-31). Excavations of an Iron Age homestead at Aldclune, Perthshire also recovered small quantities of slag in the fills of interior post ring pits (Hingley et al 1997, 423). Although such secondary associations obviously hinder reconstruction of in situ metalworking practices, the occurrence of slag is still informative as it aids the general recognition and mapping of ironworking evidence in Iron Age Scotland, at least on a broad level. But discussions can move beyond regional mapping. Hingley (1997) has suggested that the study of ironworking should consider its symbolic and social nature. This may be related to the location of metalworking and the deposition of debris in particular places. It is possible that the slag from Seafield can be interpreted within such a framework.

There is good evidence for in situ ironworking activity at Seafield. This is indicated by the association of a suite of macro- and microscopic ironworking debris and hearth lining in association with a structural feature interpreted as a hearth. In total, this accounts for $65 \%$ of the total slag assemblage. Excavation of Structure G/H revealed a later hearth (127) which was constructed from edge-set stones, with an internal fill (128) which contained abundant charcoal, ash and slag. Combined, this structural and artefactual evidence compellingly points to an in situ ironworking area, although the total quantity of hammerscale is small. This feature, radiocarbon dated to $180 \mathrm{BC}-\mathrm{AD} 70$ at $2 \sigma$ (based on associated debris from the adjacent feature, GU-
8032), represents one of the few dated in situ Iron Age ironworking episodes in Scotland.

\subsubsection{Discussion}

Placing the Seafield West ironworking debris into a wider context is difficult. There is no synthetic study of ironworking practices in Iron Age Scotland and attempts to build one are hindered by the wide variation in recording, interpretation and publication of past examples (see Hunter, Cowie \& Heald 2007). While a broad picture can be constructed from older literature, we are reliant on recent excavations for a more detailed understanding. The on-going research of the multi-phased site at Old Scatness Broch, Shetland is a particularly good example of the information that can be obtained from systematic study (Nicholson \& Dockerill 1998; McDonnell 1998).

Although there are no regional models for ironworking for northern and eastern mainland Scotland, recent excavations in and around the Seafield area have produced ironworking evidence of apparent similar date (eg Kintore, Aberdeenshire and Culduthel, Highland). The latter site is particularly important as, like Seafield, the slag is associated with in situ working areas. It is these primary features, with their metalworking debris, and their associated dates, that are critical for building up a picture of ironworking practices in Scotland. Analysis of this ever-expanding corpus must be a key future research topic.

At present, one useful approach is to consider the wider issue of the status of ironworking on such sites. A study of ironworking in central southern England has shown that it took place at many different types of sites, with smithing expected at most settlement sites (Salter \& Ehrenreich 1984, 152). Thus, the numerous smithing episodes shown by the Seafield hearth bottoms may be indicative of such everyday 


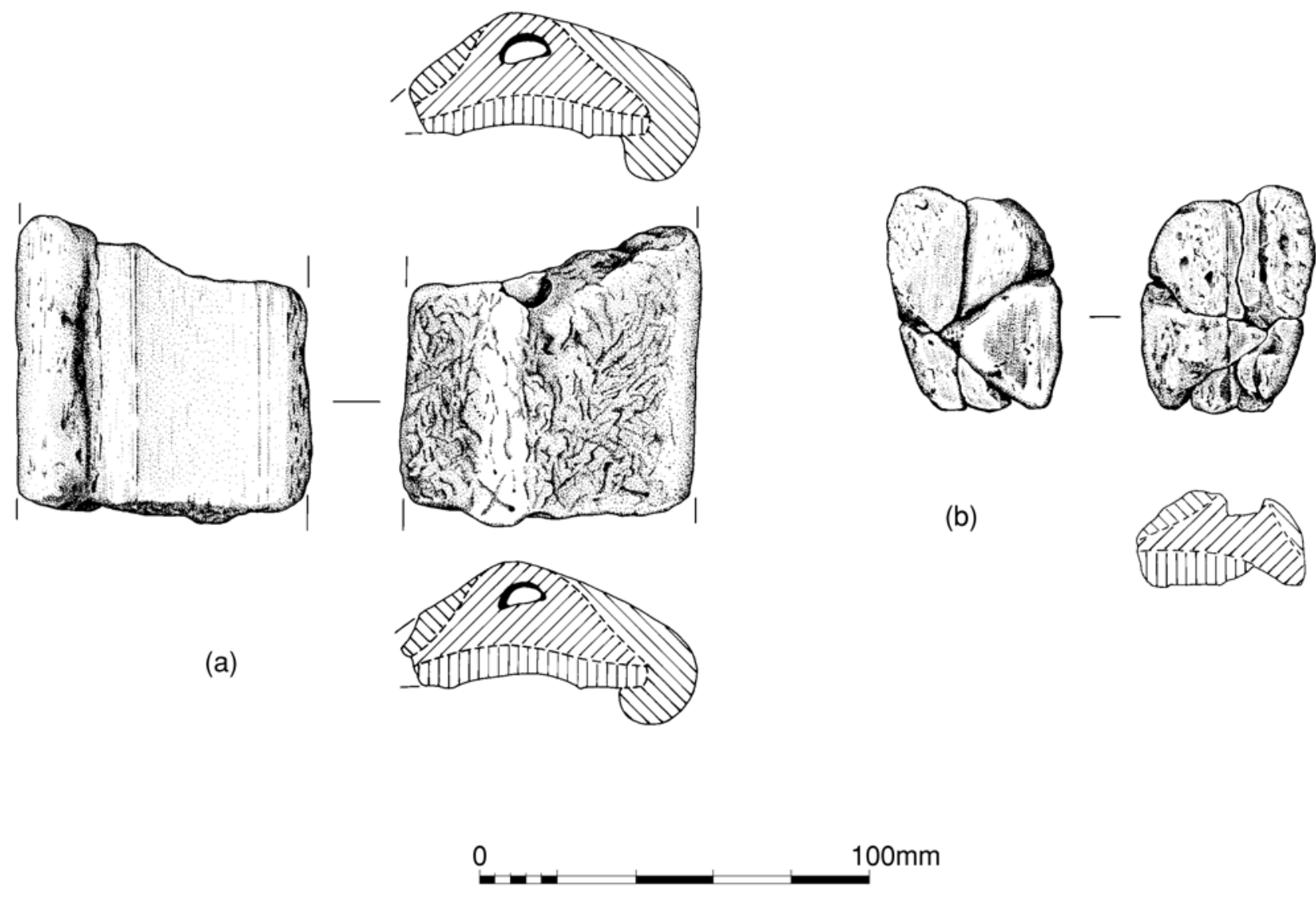

Illus 14 Fragments of BA leaf-shaped sword moulds

activity. Indeed, at face value the wide range of structural types from which slag derives may give this model some credence. However, this need not indicate prosaic craftsmanship. Norse sagas and Irish poetry clearly demonstrate the importance of smiths in these societies (see Scott 1990, 171-207; Gillies 1981), and the crafts of the smith underpinned many aspects of Iron Age society, from agriculture to warfare. There may have been different types of smith, from village blacksmith to specialist weapons smith, though it is not at present possible to distinguish them in the archaeological record. Thus, ideas that smithing was an everyday, prosaic activity often confined to the reuse of an abandoned building can be challenged: the presence of ironworking debris may be interpreted as evidence of high status, with the smithy at the heart of the settlement organisation (McDonnell 1998, 160). Along with the two Roman finds from Seafield West, it is tempting to suggest that the inhabitants were of some importance, with access to high status goods and craftspeople.

This is an area requiring much more work. The patterns are unlikely to be uniform and, as with much of the Iron Age, we should expect regional variation. The lack of in-depth study of ironworking production and consumption in Iron Age Scotland continues to hinder discussion. At present, it is difficult to decide whether ironworking was an activity common on most sites or whether smithing knowledge and skills were privileged information.
The evidence of in situ ferrous metalworking at Seafield is an important building block in this developing picture.

\subsection{Fragments of Bronze Age sword moulds, by Trevor Cowie with Katherine Eremin}

Fragments of clay moulds (illus 14) were recovered from a post-hole $(085$, fill 086) within Structure E (illus 3) and from a possible non-structural pit (071, fill 072) within Structure F. To anticipate the conclusions set out below, they represent portions of one or more ceramic piece-moulds designed for the casting of Late Bronze Age leaf-shaped swords. The find represents a significant addition to the small number of sites in Scotland which have produced metallurgical workshop debris of the period (Cowie \& O'Connor 2007, 325, fig. 28.11; Hunter et al 2007, 53, fig. 2). A charcoal sample from post-hole fill 086 produced a radiocarbon date of $1260-920 \mathrm{cal} \mathrm{BC} \mathrm{(2} \mathrm{\sigma ;} \mathrm{AA-35528),}$ a date well in keeping with the current view that the insular leaf-shaped sword manufacturing tradition had fully emerged by the 10th century cal BC.

\subsubsection{Mould fragment from post-hole 085 (illus 14a)}

Context 085 lay physically within, but not necessarily contemporary with, the setting relating to 
Structure E, and consisted of a post-hole, $0.7 \mathrm{~m}$ in diameter and some $0.5 \mathrm{~m}$ deep, with a charcoalflecked sandy fill containing packing material (086). From this was retrieved a relatively intact portion of a complex clay mould unit. A tiny featureless detached crumb in a similar fabric was present among the associated loose soil debris, but is not discussed further.

This is a relatively intact portion of a clay mould unit composed of three principal layers: an inner valve, a backing layer which would have been combined with a reinforcing splint, and an outer wrap. Although the crumbly outer layer has broken away along one side, along the midline the full profile is available from metal contact surface to the apex of the outer wrap. Two features may be noted here, namely the unworn condition of the metal contact surfaces and, in spite of the softness of the fabric, the survival of the longitudinal void left by the reinforcing splint. These features tend to suggest that wherever the metalworking activity took place, this piece was exposed to only limited wear and tear following the casting process and prior to its incorporation into the post-hole fill.

The matrix and contact surfaces survive to their full width. Both are reduced to a light grey colour (Munsell 10YR 6/2 'light brownish grey'). The matrix clearly represents part of a mould for a blade with a curved profile and a width of 31$32 \mathrm{~mm}$. In the light of comparative metallurgical debris from other sites and the known inventory of Bronze Age metalwork, there is no doubt that this is part of a piece-mould for casting a Late Bronze Age leaf-shaped sword. Mainly along the middle of the matrix surface, there is a series of very fine longitudinal striations, which appear to be the result of the displacement of tiny mineral grains, possibly as the result of 'dragging' of looser material during the pouring of the metal. An alternative but less likely explanation is that the striations are the result of deliberate smoothing of the matrix surface preparatory to casting.

The inner valve contact surfaces are approximately $10 \mathrm{~mm}$ wide. A slight rib demarcates the inner edge of the contact surface where it meets the edge of the actual matrix. It is likely that the low rib may have played a part in the registration of the opposing valves, assuming it keyed into a corresponding groove. This may explain the apparent absence of evidence of any more formal method of registration of the valves, such as the provision of tenons seen on a number of contemporary mould assemblages (eg Traprain: Cree \& Curle 1922; Jarlshof: Curle 1933). However, the absence of such keying on this particular portion of the Seafield mould assembly is not conclusive and it could simply be the fortuitous result of the spacing arrangement.

The inner valve itself consists of a $7 \mathrm{~mm}$ thick layer of finely prepared clay with fine mineral inclusions including quartz grains $(<1 \mathrm{~mm})$ and reddish-yellow (7.5YR 7/6) in colour. In view of the quality of preservation of this portion of mould, thin-sectioning was discounted but reference may be made to the results of analysis of the closely similar fabric of small fragments from pit fill 072 (see below). Under magnification especially, the building lines show clearly in the faces at either end of the mould.

As noted above, the full profile is available from metal contact surface to the apex of the outer wrap, and the method of construction of the mould is clear. The reverse of the inner valve appears to have been covered in a backing layer of clay into which has been pressed a supporting splint of organic material, presumably wood, its presence revealed by a D-shaped void $12.5 \mathrm{~mm}$ in width and $7 \mathrm{~mm}$ high. The splint appears to have been encased in its own rounded envelope of clay, prior to the application of an outer envelope or wrap of clay mixed with profuse organic tempering. Along the central spine of the mould this outer application may have been fairly thin, but around the sides it certainly consisted of a substantial layer up to $15 \mathrm{~mm}$ thick which physically enveloped the opposing valves until broken open after casting. The outer wrap is much coarser in composition, with profuse organic tempering and a deeper reddish colour (5YR 6/6 'reddish yellow').

The overall dimensions of the fragment are as follows: L 77mm; W 75mm; T 47mm.

\subsubsection{Mould fragment from pit 071 (illus 14b)}

Lying approximately $5 \mathrm{~m}$ to the east of post-hole 085 , context 071 was a small sub-circular pit, $0.5 \mathrm{~m}$ diameter and $0.27 \mathrm{~m}$ deep, with a fill of dark brown orange sand containing packing material (072). The pieces of clay mould were retrieved from the surface of the feature.

Fifteen pieces of clay mould were presented for examination, but some of these are no larger than crumbs. Five of the largest pieces join to make up part of a double-layered mould unit (as illustrated). Three detached pieces may also be noted here: these do not actually refit, but their profile, fabric and colour, and the presence of small areas of reduced surface, suggest that these are almost certainly fragments of the inner valve of the same mould unit. Two of these detached pieces were submitted for thin-sectioning and fabric analysis by Dr Suzanne Miller (formerly Department of Geology, National Museums of Scotland). The sharply contrasting red-grey colour of a further two tiny slivers suggest that they derive from the face of the void left by the reinforcing splint, and these also were submitted for analysis. The remaining pieces are too small to comment on. To summarise, the petrological thinsections showed that three of the four fragments were compositionally indistinguishable. All contained moderately or well-sorted quartz grains, mainly angular, in a very fine-grained well-mixed clay matrix, with minor mica and opaque grains; in each case, the reddish colour was due to extensive iron staining of the matrix. 
In all probability therefore, all the pieces derive from the same mould unit. Owing to the extremely powdery nature of the surfaces and inherent softness of the fabric, it is not certain whether the fragmentation occurred in antiquity, or is the result of compression while in the soil. In any case, this portion of mould has clearly undergone considerably more abrasion prior to incorporation in the soil than the portion from context 086 .

As noted above, five pieces refit to form an incomplete portion of a double-layered mould unit. The inner layer survives on only one of the pieces, along with a small area of the matrix surface, approximately $24 \mathrm{~mm} \times 20 \mathrm{~mm}$. The profile is incomplete but clearly represents part of the matrix for a blade $25-30 \mathrm{~mm}$ in width at this point, in all probability a sword blade, given the close similarity to the better preserved mould fragment from context 086 . The question of whether the two finds represent elements of the same mould assembly is considered in the discussion. The metal contact surface is reduced to a light grey colour (Munsell 10YR 6/2). Although scored in places by subsequent abrasion, parts of the surface are relatively well preserved, retaining a number of fine longitudinal striations similar to the piece from 086. The valve contact surface is damaged and its original form is uncertain: a slight rib demarcates the edge of the actual matrix and running parallel to this is a narrow, slightly irregular scored line $(0.5 \mathrm{~mm}$ across $)$. The functions of the rib and the scored line are uncertain, but as noted above, these features may possibly have a connection with registration of the opposing valves. The inner valve consists of a layer of clay approximately $6-7 \mathrm{~mm}$ thick: the building line shows clearly in profile where the double layers are preserved, and where the inner wrap has become detached, the line of the junction survives as a smooth curve. The inner valve fabric consists of fine clay, with very fine inclusions $(<1 \mathrm{~mm})$; the surface is a reddish yellow (7.5YR 7/6).

Turning to the enveloping structure, a U-shaped channel represents the abraded remains of the void left by a supporting splint of organic material applied to the reverse of the inner valve and encased in clay. As in the case of 086, the splint appears to have been encased in its own envelope, prior to the application of the outermost envelope or wrap. Few traces of the outermost wrap now remain, probably due to abrasion of the extremely soft and powdery surfaces. The fabric of the outer wrap is profusely tempered with organic material. The surfaces are a deeper red colour (5YR 6/6 'reddish yellow').

As noted above, the fabric and colour of two tiny detached slivers suggest that they derive from the face of the void left by the reinforcing splint, where burning out of the splint has resulted in a reduced grey surface.

The overall dimensions of the fragment in its refitted condition are as follows: maximum length: $60 \mathrm{~mm}$; maximum width: $45 \mathrm{~mm}$; maximum thickness: $25 \mathrm{~mm}$

\subsubsection{XRF analysis of the mould fragments, by Katherine Eremin}

In order to assist with identification of the casting alloy, the mould fragments were analysed by using energy dispersive X-ray fluorescence (XRF) without any preparation (Eremin 2000). Some alteration of the surface chemistry due to burial is expected.

Copper and lead were detected by X-ray fluorescence analysis of the central grey areas of both mould fragments. A number of elements were found in all areas detected and are constituents of the ceramic: iron, titanium, potassium, calcium, manganese, rubidium, strontium and zirconium. The presence of lead and copper in casting areas suggests casting of a leaded copper alloy. Although tin was not detected in the mould fragments, it may have been present in the alloy as tin is not a volatile element, hence is not strongly absorbed by the ceramic.

\subsubsection{Discussion}

The find represents an important addition to the small number of sites in Scotland which have produced Late Bronze Age clay moulds. These include the significant assemblages from Traprain Law, East Lothian and Jarlshof, Shetland and smaller groups recovered from Dunagoil, Bute and Loanhead of Daviot, Aberdeenshire (see Hodges 1959; Coles 1960, 89).

In keeping with finds from other sites in Scotland and further afield in Britain and Ireland, Seafield West shows careful preparation of the mould units, with the use of different recipes for the production of the inner valves and outer wraps. The clay for the inner valve had been carefully worked, while the outer layer was a coarser mix incorporating substantial quantities of plant matter. As noted above, the Seafield West moulds provide particularly clear evidence of the use of enclosed wooden splints. Such reinforcement of the mould assembly would have been required to prevent warping of the mould during the manufacture of long implements, such as swords. There is evidence of the use of reinforcing splints among the metalworking debris from Traprain Law (Cree \& Curle 1922, 214, fig. 14.2) and Jarlshof (Curle 1933, 116; 1934, 279). In Ireland, there is evidence for broadly similar devices from Boho, Co. Fermanagh (Hodges 1954, 64); Lough Eskragh, Co. Tyrone and Whitepark Bay, Co. Antrim (Collins 1970, 34-6, nos 26, 30-31).

Tylecote $(1986,89)$ has noted the remarkably consistent form of Late Bronze Age moulds in Britain and Ireland, but it should be stressed that the precise method of manufacture of the mould varies in detail. Whereas the moulds from the above-mentioned sites have a two-part structure, the pattern of building joints shows quite clearly that at Seafield the mould assembly was tripartite, the splint being encased within a clay backing applied to the inner valve prior to application of the outermost wrap. 
The structure gives the Seafield mould a bulkiness which contrasts with the neater lines of the mould units from Jarlshof and Traprain. Another contrast is the apparent absence of any formal method of keying to permit registration of the opposing halves of the mould assembly. It is unclear whether these simply reflect differences in technique or expertise (for example, as a result of more careful preparation of the clay) or technological advances achieved over time.

On the fragment from 086, the matrix indicates a segment of blade with relatively straight sides, 30$31 \mathrm{~mm}$ in width, and with a gently rounded section, a combination of features which invites comparison with the neck portion of a leaf-shaped sword blade. The projected width and profile of the matrix on the less well-preserved mould fragment from 072 would also be in keeping with the neck of a sword. The close similarity of the two fragments may be noted, but owing to the incompleteness of 072 , it is not certain whether they represent portions of the same original mould assembly. Similarly the incompleteness of the mould fragments precludes detailed classification of the sword type.

In the light of radiocarbon dating, the development of leaf-shaped swords was taking place in Britain during the period $c$ 1150-950 cal BC (Needham 1996, 135-6; Needham et al 1997). The radiocarbon date of $1260-920$ cal BC obtained from context 086 is thus well in keeping with the current view that the insular leaf-shaped sword manufacturing tradition had fully emerged by the 10th century cal BC, but evidence from the swords themselves suggests that they were not being manufactured in Scotland before the Ewart Park phase (9th century BC) of the Late Bronze Age (Cowie \& O'Connor 2007).

\subsection{Fired clay, by Fraser Hunter}

Chunks of fired clay were recovered from the fills of a number of features spread across the site. Most were either unworn or only slightly worn, indicating that they had become incorporated into the deposits shortly after destruction as such friable material weathers rapidly. Although often described as burnt daub, it is unlikely they come from the burnt clay walls of houses: they have flat rather than curved faces, the temperatures indicated by the appearance of some, and the presence of slag adhering to another, suggests instead they derive from an industrial process. Insufficient survives to reconstruct their original form. The slag on one suggests metalworking, which is attested on site by fragments of LBA sword mould and Iron Age slag: they may come from structures associated with metal-working, such as hearths and casting pits. The lack of curvature indicates we are not dealing with furnace lining.

Impressions in the fragments indicate that a rightangled framework of wattles was used as a support, with wattles running parallel to and immediately behind the face; there is no surviving evidence for a three-dimensional framework. Wattle diameters vary from 10 to $25 \mathrm{~mm}$. As to morphology, a number of different features are indicated. Some are thin slabs, some $18-26 \mathrm{~mm}$ thick. Where two faces survive they are generally perpendicular, although some are at a more acute angle and one has an obliquely rounded edge. One preserves a raised lip, suggesting it lay on the inside of an angle.

The material was recovered from features associated with six of the structures. A small post-hole (030) within the ring of Structure A contained a single, highly fired fragment; small slag fragments were found in other features situated adjacent to the ring-groove. The entrance post-hole 411 of Structure B contained both slag and highly fired clay, one piece with a wattle impression. Post-hole 459 within the ring of this structure also contained a small fragment. Within ring-ditch Structure C, six fragments of fired clay came from adjacent small post-holes 381 and 158 , the former producing the largest (by weight) single assemblage from the site at $259 \mathrm{~g}$ but also containing ?intrusive modern material. Post-holes 085 and 076 within the ring of Structure E (but possibly relating to Structure F) contained small quantities with parallel faces; 085 was the feature which produced the larger of the clay mould fragments (Cowie above). Features associated with the hearth in Structure H and nearby post-holes in Structure G contained a total of 25 pieces, including vitrified fragments, rightangled faces and wattle impressions. Potentially these fragments could be the remains of hearth lining and a dome over metalworking hearth 127 . 


\section{ENVIRONMENTAL ANALYSES}

An environmental sampling strategy was established using both standard and judgemental methods to obtain routine soil samples from relevant archaeological deposits, and where appropriate, target deposits and other features regarded as archaeologically significant.

\subsection{Bone, by Sue Anderson}

A total of 292 fragments of bone were hand-collected from nineteen features; material collected from samples was not analysed as it was all too small for identification. The majority of this material was calcined and heavily fragmented. The main exceptions were a single juvenile cattle metapodial shaft from pit 381 in Structure C and an unidentified fragment in post-hole 020 within Structure A; these unburnt pieces may indicate a recent date for those features, or potentially intrusive finds. Unburnt fragments were also collected from earlier features, but these were all fragments of tooth enamel, which tends to survive where bone does not. Most of the burnt fragments were too small for identification, but all were probably of animal rather than human origin. However, a few small fragments of ?fallow deer antler were recovered from pit 138 (near Structure C) and post-hole 427 (entrance to Structure B inner ring). The latter included a tine which appeared to have been cut across the tip (although calcined bone can have this appearance due to shearing of the bone during burning), and there was a small shaped fragment, possibly also antler, which is indicative of bone/antler working. The fragment measured $11 \mathrm{~mm}$ in length and was roughly shaped with an irregular hexagonal section $(5 \times 4 \mathrm{~mm})$; it may be a roughout for a pin shaft which was broken and discarded.

This bone represents only a small fraction of the animal remains once present on the site, but the acidic nature of the soil ( $\mathrm{pH}$ 5.6) has resulted in the loss of all unburnt material other than a few fragments assumed to be of recent date. Despite this, study of the material has provided limited evidence for working of osseous material, adding another dimension to the craft and industrial activities which took place on the site.

\subsection{Charred plant remains, by Ruth Pelling}

\subsubsection{Introduction}

As part of the excavation a series of samples was taken for the extraction of charred plant remains.
Typical sample contexts included occupational deposits (Structures B and C), the enclosure ditch of Structure B, a variety of other pits and post-holes. Where possible every context related to a fill was sampled. Forty per cent of the total assemblage was processed for plant macro remains. Sample size varied according to the nature of the feature being excavated. Post-hole samples were in the region of 10-15 litres, while more substantial samples of 20 to 57 litres were taken from the occupation layer 034 in Structure C.

\subsubsection{Methodology}

Samples were processed by bulk water flotation. The resultant flots were collected onto $500 \mu \mathrm{m}, 1 \mathrm{~mm}, 2 \mathrm{~mm}$ and $4 \mathrm{~mm}$ mesh sizes. The flots and residues were sorted by members of CFA. For each flot $100 \%$ of the $2 \mathrm{~mm}$ and $4 \mathrm{~mm}$ fractions was sorted. For smaller samples $100 \%$ of the $1 \mathrm{~mm}$ fraction was also sorted, while for larger flots $25 \%$ or $50 \%$ of the $1 \mathrm{~mm}$ fraction was sorted. Any identifiable and quantifiable plant remains were extracted for identification. The $500 \mu \mathrm{m}$ flot was scanned for smaller carbonised seed remains. The residues were sorted down to $2 \mathrm{~mm}$.

Identifications of seeds and chaff were made at the Environment Unit, Oxford University Museum of Natural History, using a reference collection held in the museum. Nomenclature and taxonomic order follows Clapham, Tutin \& Moore (1987).

\subsubsection{Results}

Fifty samples were sorted, of which 29 produced small quantities of charred seeds and chaff. The results are displayed in Tables 3-6 and are discussed by feature or feature type.

\section{Structure B}

Eight samples from palisade ditch fill 004 and four post-holes within its interior produced small numbers of charred remains (Table 3). The occasional cereal grains included hulled barley but also one grain of hulled wheat which most closely resembled emmer (Triticum dicoccum). In the absence of any glume base it was not possible to be more precise with the identification.

Occasional weed seeds included Polygonum persicaria and another ruderal species Stellaria media (chickweed). A single sloe stone was also present. A single seed of possible Thalictrum sp. (meadow rue) was rather abraded. Thalictrum sp. can occur as a 
Table 3 Charred plant remains from Structure B

\begin{tabular}{|c|c|c|c|c|c|c|c|c|c|}
\hline & Sample & 75 & 87 & 88 & 94 & 121 & 133 & 136 & 155 \\
\hline & Context & 005 & 005 & 005 & 005 & 351 & 412 & 419 & 424 \\
\hline & Feature & 004 & 004 & 004 & 004 & 004 & 411 & 417 & 424 \\
\hline & Volume & 2 & 16 & 2 & 11.5 & ?8.5? & 20 & 4 & $\mathbf{2}$ \\
\hline \multicolumn{10}{|l|}{ Cereal Grain } \\
\hline Hordeum vulgare & barley, hulled grain & - & 1 & - & 3 & 1 & 2 & - & - \\
\hline Hordeum vulgare & barley grain & - & - & 1 & 1 & 1 & 1 & - & - \\
\hline Triticum cf. dicoccum & $\begin{array}{l}\text { cf. emmer wheat } \\
\text { grain }\end{array}$ & - & - & - & 1 & - & - & - & - \\
\hline Avena sp. & oats, grain & - & - & - & - & - & 2 & - & - \\
\hline Cerealia indet & indeterminate grain & 1 & 1 & - & 1 & 3 & - & 1 & - \\
\hline Chenopodium album & fat hen & - & - & - & - & - & 1 & - & - \\
\hline cf. Thalictrum sp. & meadow rue & - & 1 & - & - & - & - & - & - \\
\hline Stellaria media agg. & chickweed & - & 1 & - & - & - & - & - & - \\
\hline Polygonum persicaria & persicaria & - & - & - & - & 1 & 4 & - & 2 \\
\hline Polygonum sp. & & - & - & - & - & 1 & - & - & - \\
\hline Prunus spinosa & sloe stone & - & 1 & - & - & - & - & - & - \\
\hline Gramineae & grass, small seeded & - & - & - & - & 1 & - & - & 3 \\
\hline Gramineae & grass, large seeded & - & - & - & 3 & - & - & - & - \\
\hline Monocotyledons & $\begin{array}{l}\text { rhizome/root } \\
\text { fragment }\end{array}$ & - & 3 & - & - & - & - & 4 & 1 \\
\hline weed indet & & - & 3 & - & 1 & 1 & 2 & - & - \\
\hline
\end{tabular}

meadow species, on more rocky limestone or ridges or on sand dunes.

\section{Structure C}

Four samples from occupation layer 034 produced large flots dominated by charcoal but also containing seeds and chaff(Table 4). Grain was again dominated by hulled barley (Hordeum vulgare), including asymmetrical internal grain indicative of six-row barley (in six-row barley the ratio of asymmetrical to straight grain is 2:1). Two oat grains were also present. Chaff was restricted to three cereal-sized straw culm nodes. Dominating the assemblages in three samples, however, were numerous monocotyledon rhizome fragments. Possible Arrhenatherum elatius (false oat-grass) tubers were also present. The finds suggest some sort of uprooting or possible presence of turf.

Weeds were again dominated by arable/ruderal species such as Chenopodium album (fat hen), Polygonum persicaria (persicaria) and Fallopia convolvulus (black bindweed) and the cereal-sized grasses including Bromus subsect Eubromus (brome grass).

Some evidence of hedgerow species and possibly collection of wild resources is present in the form of hazelnut shell (Corylus avellana) and sloe stone (Prunus spinosa), although both could have entered the assemblage with firewood.

Pit 381 in this structure also produced small quantities of barley and wild species.

\section{Structure G/H}

Samples from six post-holes and two hearths in Structure G/H produced occasional grain and weed seeds (Table 5). Remains were present in a density of 1.48 items per litre of deposit. The occasional grain included hulled barley (Hordeum vulgare) and oats (Avena sp.), one of which had germinated. It is likely the germination was the result of no more than occasional spoilt crop. The different species of oats cannot be distinguished on grain alone, thus in the absence of floret base (the diagnostic part of the plant) it was not possible to determine whether the grain was from wild or cultivated oats.

No chaff was present, although weed seeds were present in six samples (post-hole fills 116 and 286 and hearth fill 128). Also present in two postholes were occasional fragments of hazelnut shell (Corylus avellana). The weeds are dominated by 
Table 4 Charred plant remains from occupation layer 034 and pit 381 in Structure C

\begin{tabular}{|c|c|c|c|c|c|c|}
\hline & Sample & 108 & 112 & 114 & 115 & 166 \\
\hline & Context & 034 & 034 & 034 & 034 & 380 \\
\hline & Feature & - & - & - & - & 381 \\
\hline & Volume & 20 & 42 & $? 20$ & 57 & 2 \\
\hline \multicolumn{7}{|l|}{ Cereal Grain } \\
\hline Hordeum vulgare & $\begin{array}{l}\text { hulled barley, twisted } \\
\text { grain }\end{array}$ & - & 1 & - & - & \\
\hline Hordeum vulgare & barley, hulled grain & 5 & 7 & 5 & 5 & 2 \\
\hline Hordeum vulgare & barley grain & 2 & 3 & - & 1 & 1 \\
\hline Avena sp. & oats, grain & - & - & 1 & 1 & - \\
\hline Cerealia indet & indeterminate grain & 5 & 2 & 1 & 1 & - \\
\hline \multicolumn{7}{|l|}{ Chaff } \\
\hline Cereal size & culm nodes & 3 & - & - & - & - \\
\hline \multicolumn{7}{|l|}{ Weed/Wild } \\
\hline Chenopodium album & fat hen & - & 2 & - & 2 & - \\
\hline Leguminoseae & small seeded & - & - & - & 1 & - \\
\hline Polygonum persicaria & Persicaria & - & - & 3 & 1 & 1 \\
\hline Polygonum sp. & & - & 2 & - & - & 2 \\
\hline Fallopium convolvulus & black bindweed & - & - & - & 1 & - \\
\hline Corylus avellana & $\begin{array}{l}\text { hazelnut shell } \\
\text { fragment }\end{array}$ & - & - & 1 & - & - \\
\hline Prunus spinosa & sloe stone & 1 & - & - & - & - \\
\hline Labiatae & large seeded & - & 1 & - & - & - \\
\hline Lapsana communis & & - & - & 1 & - & - \\
\hline Carex sp. & Sedges & - & - & - & 1 & - \\
\hline Bromus subsect Eubromus & brome grass & - & - & - & 1 & - \\
\hline cf. Arrhenatherum elatius & false oat-grass tuber & - & 2 & - & 1 & - \\
\hline Gramineae & grass, small seeded & - & 1 & - & 1 & - \\
\hline Gramineae & grass, large seeded & - & - & - & 1 & - \\
\hline Monocotyledons & rhizome/root fragment & 82 & 84 & 3 & 27 & - \\
\hline weed indet & & - & 5 & 1 & 3 & - \\
\hline berry/fruit indet & & - & - & - & 1 & - \\
\hline
\end{tabular}

common arable/ruderal species, notably Chenopodium album (fat hen) and Polygonum persicaria (persicaria).

The primary fill of post-hole 055 in Structure $\mathrm{G}$ produced an assemblage similar to those from layer (034) in Structure C. The most prominent category of remains were the large number of monocotyledon rhizomes. Hulled barley dominated the cereal remains including occasional rachis fragments. A single oat was the only other cereal present. Weeds included the ruderal/arable species (eg Chenopodium album, Polygonum persicaria). The remaining post-hole samples produced much smaller assemblages with a single oat and occasional barley grains, arable/ruderal weed seeds, grass seeds and monocotyledon rhizomes. The density of remains was very low, ranging from 0.2 to 3.5 items per litre.

Pits and other features

Three samples from two large sub-rectangular pits (146 and 152) near Structure C produced occasional remains (Table 6). All samples were very small (2 litres). Charred remains included occasional barley grain, hazelnut fragments and ruderal/arable weeds (Polygonum persicaria, Fallopia convolvulus).

Post-hole 063 in Structure F contained small quantities of barley grain and fat hen, and the ring-groove of Structure A (017) also produced barley grains. Two pits or post-holes to the south of Structure $\mathrm{H}$ 
Table 5 Charred plant remains from Structure G/H

\begin{tabular}{|c|c|c|c|c|c|c|c|c|c|c|}
\hline & Sample & 3 & 4 & 30 & 34 & 66 & 68 & 91 & 101 & 105 \\
\hline & Context & 036 & 038 & 116 & 118 & 128 & 209 & 285 & 059 & 211 \\
\hline & Feature & 035 & 037 & 119 & 119 & 127 & 208 & 124 & 055 & 207 \\
\hline & Volume & 23 & 0.2 & 4.5 & 4.5 & 2 & 2 & 2 & $2 ?$ & 2 \\
\hline \multicolumn{11}{|l|}{ Cereal Grain } \\
\hline Hordeum vulgare & hulled barley, twisted grain & - & - & - & - & - & 1 & - & - & - \\
\hline Hordeum vulgare & hulled barley, straight grain & - & - & - & - & - & 1 & - & - & - \\
\hline Hordeum vulgare & barley, hulled grain & 1 & - & 2 & 2 & - & 3 & 3 & 4 & - \\
\hline Hordeum vulgare & barley grain & 1 & 3 & 1 & - & - & - & - & 5 & - \\
\hline Avena sp. & oats, germinated grain & 1 & - & - & - & - & - & 1 & 1 & - \\
\hline Avena sp. & oats, grain & - & - & - & - & - & - & 1 & - & - \\
\hline Cerealia indet & indeterminate grain & - & - & - & - & - & 2 & 4 & 5 & - \\
\hline \multicolumn{11}{|l|}{ Rachis } \\
\hline Hordeum vulgare & barley rachis & - & - & - & - & - & - & - & 5 & - \\
\hline Cerealia indet & rachis & - & - & - & - & - & - & - & 3 & - \\
\hline \multicolumn{11}{|l|}{ Weed/Wild } \\
\hline Chenopodium album & fat hen & 1 & - & - & - & 2 & - & 5 & 4 & - \\
\hline Atriplex sp. & Orache & - & - & - & - & - & - & 1 & - & - \\
\hline Polygonum persicaria & Persicaria & - & - & 1 & - & - & - & 5 & 1 & - \\
\hline Corylus avellana & hazelnut shell fragment & - & - & - & - & - & - & 7 & - & 1 \\
\hline Labiatae & large seeded & - & - & - & - & - & - & 1 & 2 & - \\
\hline Bromus subsect Eubromus & brome grass & - & - & - & - & - & - & - & 1 & 1 \\
\hline Gramineae & grass, small seeded & - & - & - & - & 1 & - & - & 3 & - \\
\hline Monocotyledons & rhizome/root fragment & - & - & - & - & - & - & 1 & 57 & - \\
\hline weed indet & & 1 & - & - & - & - & - & 2 & 2 & 2 \\
\hline bud indet & & - & - & - & - & 1 & - & - & - & - \\
\hline
\end{tabular}

(232 and 240) contained small quantities of grain and weed seeds.

\subsubsection{Discussion}

Charred plant remains occurred in low densities in the samples, but were consistently present. Cereal remains suggest some cereal cultivation or at least utilisation. The general absence of chaff makes it difficult to make any statement about cereal production/preparation. The weed seeds may in part have derived from weeds within the arable crop which entered the assemblages as sieving waste.

The cereal crop record is consistent with other sites of this date in northern Scotland. Barley is both wind and salt tolerant so is well suited to northern coastal environments. It formed the principal cereal throughout mainland Scotland and the islands at this time (Boyd 1988). While it is possible that emmer wheat was also being cultivated there is no evidence of it being a significant crop at the site and it may simply be present as a weed of the barley crop. Emmer wheat was cultivated throughout the prehistoric period in Scotland and does appear to be the secondary cereal at many sites (ibid). Given the absence of oat chaff it was not possible to establish if the oats were cultivated or wild. Evidence of Avena strigosa (cultivated oats) does exist for the first time in Scotland in the Iron Age.

The weed assemblages contain several species characteristic of spring-sown barley. Included in this group are Chenopodium album, Fallopia convolvulus and Stellaria media. There is a slight hedgerow element with the Corylus avellana and Prunus spinosa. There is no evidence of heathland exploitation. Arrhenatherum elatius is a coloniser of abandoned arable or of pasture which ceases to be grazed. It is a characteristic species of succession to scrub land. The presence of the tubers in association with large numbers of rhizomes might indicate the use of turves as fuel. Evidence of the use of turves, although more commonly of heathland, has also been recorded at Late Bronze Age sites in the Isles 
Table 6 Charred plant remains from other features

\begin{tabular}{|c|c|c|c|c|c|c|c|c|}
\hline & Sample & 11 & 12 & 71 & 74 & 79 & 96 & 97 \\
\hline & Context & 064 & 016 & 142 & 233 & 241 & 149 & 151 \\
\hline & Feature & 063 & 017 & 146 & 232 & 240 & 152 & 152 \\
\hline & Volume & 4 & 16 & 2 & 4 & 2 & 2 & 2 \\
\hline \multicolumn{9}{|l|}{ Cereal Grain } \\
\hline Hordeum vulgare & barley, hulled grain & 2 & - & 2 & - & - & - & - \\
\hline Hordeum vulgare & barley grain & - & 2 & - & 1 & - & - & - \\
\hline Cerealia indet & indeterminate grain & - & - & - & - & - & - & 1 \\
\hline \multicolumn{9}{|l|}{ Weed/Wild } \\
\hline Chenopodium album & fat hen & 1 & - & - & - & 1 & - & - \\
\hline Polygonum persicaria & persicaria & - & - & - & - & - & - & 2 \\
\hline Polygonum sp. & & - & - & - & - & - & - & 1 \\
\hline Fallopium convolvulus & black bindweed & - & - & - & - & - & - & 1 \\
\hline Corylus avellana & $\begin{array}{l}\text { hazelnut shell } \\
\text { fragment }\end{array}$ & - & - & 1 & - & - & 2 & - \\
\hline Monocotyledons & rhizome/root fragment & - & - & - & - & - & - & 1 \\
\hline weed indet & & - & - & - & 1 & - & - & 1 \\
\hline
\end{tabular}

of Scilly (Ratcliffe \& Straker 1996), from Hengistbury Head in Dorset (Nye \& Jones 1987, 323) and from Late Iron Age hearth deposits from Howe in Orkney (Dickson 1994). Fenton $(1978,207)$ records the more recent use of heathland turves for fuel in the absence of available peat in Orkney.

Such assemblages are typical of small-scale subsistence cereal production (van der Veen 1991, 121); there is no evidence of surplus production. It is possible that the cereal diet was supplemented by the collection of wild resources such as hazelnut and sloe although, as mentioned above, these remains may have derived from firewood.

\subsection{Charcoal, by Michael Cressey}

Charcoal was identified to species level on samples

Table 7 Charcoal species and total weight

\begin{tabular}{lcc}
\hline Species & total weight $(\mathbf{g})$ & main type \\
\hline Salix sp. & 0.56 & $\mathrm{sf}$ \\
Rosaceae type & 20.25 & $\mathrm{rw}$ \\
Quercus sp. & 48.90 & $\mathrm{t}$ \\
Alnus glutinosa & 0.29 & $\mathrm{sf}$ \\
Corylus avellana & 72.58 & $\mathrm{rw}$ \\
Pinus sylvestris & 0.26 & $\mathrm{sf}$ \\
Prunus type & 0.26 & $\mathrm{sf}$ \\
Betula type & 25.53 & $\mathrm{rw}$ \\
\hline
\end{tabular}

Key: sf=single fragment, $\mathrm{rw}=$ roundwood, $\mathrm{t}=$ mainly timber recovered from post-holes, pits, suspected occupation layers and palisade slots in order to select adequate material for radiocarbon dating. Other information on the types of wood that was available for exploitation during the sites occupation has been obtained. The samples examined include both hand-picked samples from secure contexts and samples from routine wet-flotation. In addition to the hand-picked samples, approximately 25\% (representing 40 bulk samples) was subjected to processing by flotation. Table 7 summarises the results by species.

\subsubsection{Roundwood and timber}

Eight species of roundwood and a large quantity of timber are represented in the charcoal assemblage from the site. Quercus sp. (oak) and Corylus avellana (hazel) are the most dominant species, represented by $48 \mathrm{~g}$ and $72 \mathrm{~g}$ of charcoal respectively, followed by $25 \mathrm{~g}$ of Betula sp. (birch) charcoal. Rosaceae type (apple, cherry and hawthorn group) provided 20g of charcoal. Salix (willow), Pinus (pine) and Alnus glutinosa (alder) provided only trace amounts of charcoal at below $1 \mathrm{~g}$.

\subsubsection{Charcoal cache associated with the smithing hearth}

A large quantity of oak charcoal $(2.2 \mathrm{~kg})$, all derived from squared timber, was recovered from post-hole 207, part of Structure G. Of this material, $12 \%$ consisted of worked fragments with either oblique facets, or evidence for saw-cuts and adze marks. 
Table 8 Comparative species abundance derived from Seafield West 1 and 2 and Beechwood Farm

\begin{tabular}{llc}
\hline Site and type & Species & \% abundance \\
\hline Seafield West 1 (Pyre deposit) & Corylus avellana & 71 \\
& Betula sp. & 9 \\
Seafield West 2 occupation sites & Quercus sp. & 14 \\
& Corylus avellana & 49 \\
Beechwood Farm, burnt mound \& trough & Betula sp. & 17 \\
& Quercus sp. & 33 \\
& Corylus avellana & 60 \\
\hline
\end{tabular}

Some of the oak fragments are large $\left(20-30 \mathrm{~mm}^{3}\right)$ : it is probable that large fragments of oak charcoal were selected in favour of other types of wood in order to maintain the high temperatures required for metalworking. Conversely, the large quantity of oak may simply represent a large quantity of waste material that was readily available for conversion to charcoal for smithing purposes. It is important to note here that the charcoal recovered from post-hole 207 is a product of manufacture in its own right and would have been produced in a small 'stack', covered with soil and allowed to burn in reducing conditions until the carbonisation process was completed (Hodges 1989).

\subsubsection{Comparative species abundance at two nearby Prehistoric sites}

Comparisons between the species abundance of hazel, birch and oak from Seafield West Area 1
(Cressey \& Sheridan 2003) and Area 2 and the nearby Beechwood Farm burnt mounds and trough (Cressey \& Strachan 2003) are provided in Table 8. The data from these three sites show that hazel was locally dominant within the Late Bronze Age and Iron Age. Hazel thrives on base-poor soils typical of the type found at Seafield West. Birch, a lightdemanding pioneer, and oak are also trees that can thrive on fairly acid soil and both are a well-represented component of woodland throughout Scottish Prehistory.

\subsection{Radiocarbon dating}

Five single entity (AMS) charcoal samples (cf Ashmore 1999) and one bulk charcoal sample retrieved by wet sieving were submitted to the Scottish Universities Research Reactor Centre (SURRC) for radiocarbon dating. The charcoal consisted in all cases of non-abraded pieces within

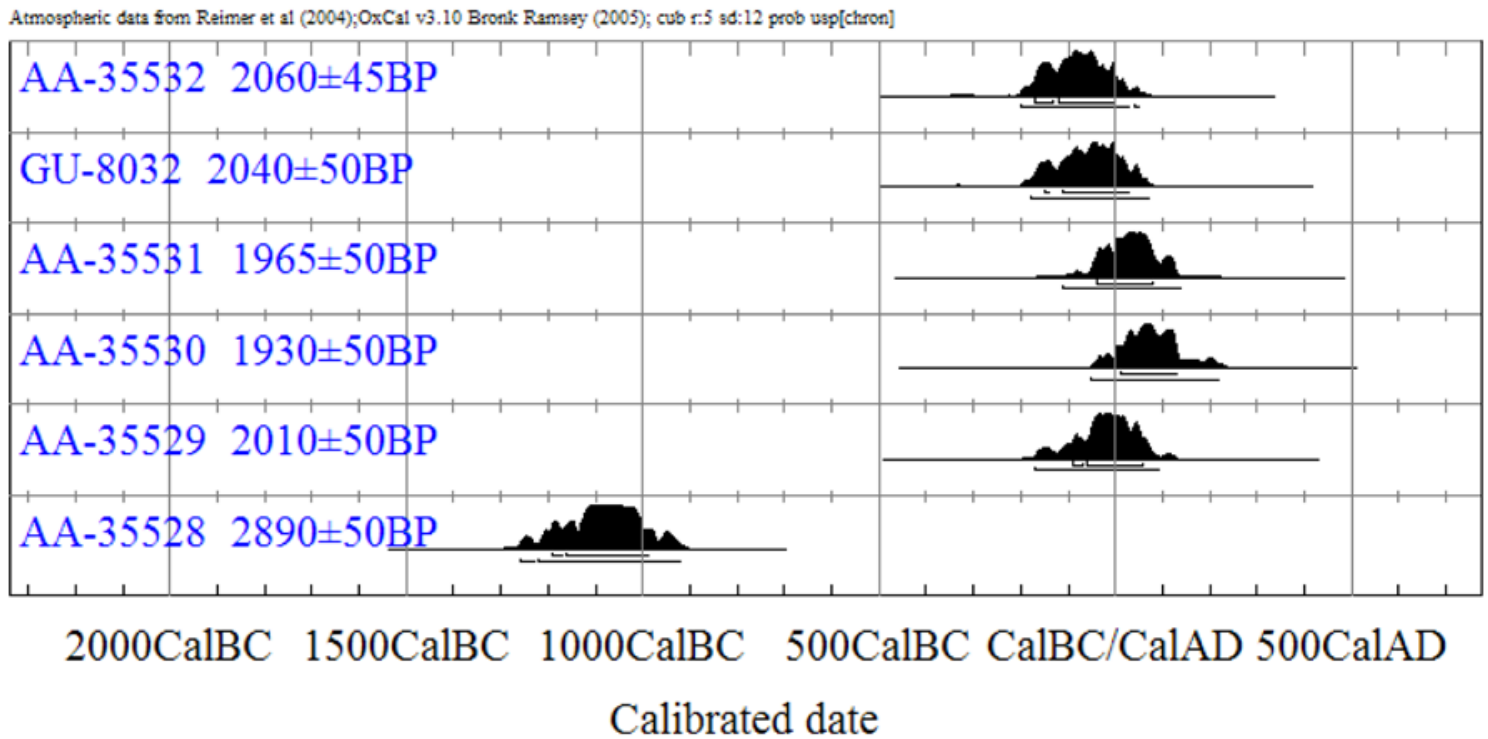

Illus 15 Graph showing the distribution of calibrated radiocarbon dates 
Table 9 Radiocarbon dating results

\begin{tabular}{|c|c|c|c|c|c|}
\hline Lab no. & Feature & Material & Age BP uncal & Age range at $2 \sigma$ & \& $13 \mathrm{C}(\% o)$ \\
\hline $\begin{array}{l}\text { GU-8593 } \\
(\mathrm{AA}-35528)\end{array}$ & $\begin{array}{l}\text { Pit } 085 \text { in } \\
\text { Structure E (fill } \\
\text { 086) }\end{array}$ & Betula sp. charcoal & $2890 \pm 50$ & cal 1260 BC-AD 920 & -25.7 \\
\hline $\begin{array}{l}\text { GU-8488 } \\
(\mathrm{AA}-35532)\end{array}$ & $\begin{array}{l}\text { Structure G post- } \\
\text { hole } 111 \text { (fill 113) }\end{array}$ & $\begin{array}{l}\text { Corylus avellana } \\
\text { charcoal }\end{array}$ & $2060 \pm 45$ & cal 200 BC-AD 50 & -26.5 \\
\hline GU-8032 & $\begin{array}{l}\text { Hearth cache } \\
125 \text {; upper fill of } \\
\text { Structure G post- } \\
\text { hole } 207\end{array}$ & $\begin{array}{l}\text { Corylus avellana } \\
\text { charcoal }\end{array}$ & $2040 \pm 50$ & cal 180 BC-AD 70 & -26.4 \\
\hline $\begin{array}{l}\text { GU-8491 } \\
\text { (AA-35529) }\end{array}$ & $\begin{array}{l}\text { Structure B1 post- } \\
\text { hole } 447 \text { (fill 448) }\end{array}$ & $\begin{array}{l}\text { Corylus avellana } \\
\text { charcoal }\end{array}$ & $2010 \pm 50$ & cal 170 BC-AD 90 & -28.2 \\
\hline $\begin{array}{l}\text { GU-8489 } \\
\text { (AA-35531) }\end{array}$ & $\begin{array}{l}\text { Fill } 351 \text { in } \\
\text { terminal of } \\
\text { Structure B2 } \\
\text { palisade trench }\end{array}$ & $\begin{array}{l}\text { Quercus sp. } \\
\text { charcoal }\end{array}$ & $1965 \pm 50$ & cal 110 BC-AD 140 & -24.6 \\
\hline $\begin{array}{l}\text { GU-8490 } \\
\text { (AA-35530) }\end{array}$ & $\begin{array}{l}\text { Structure B post- } \\
\text { hole } 417 \text { (fill } 419 \text { ) }\end{array}$ & $\begin{array}{l}\text { Quercus sp. } \\
\text { charcoal }\end{array}$ & $1930 \pm 50$ & cal 50 вС-AD 220 & -25.2 \\
\hline
\end{tabular}

a sample size of $c 3-4 \mathrm{~mm}$. Table 9 lists the results obtained from radiocarbon dating. The calibrated age ranges were determined using Oxcal ver 3.10 software and illus 15 shows their relative distribution against the radiocarbon calibration curve.

The radiocarbon date obtained from the same context as the sword mould places it firmly within the Late Bronze Age, and provides indirect evidence for possible occupation and metalworking activity of this period here.

The results from radiocarbon dating on charcoal recovered from the post-pipe within post-hole 111 that formed part of Structure G, and the charcoal fuel cache (125) which formed the upper fill of posthole 207 fall within the same radiocarbon age range and overlap statistically. It is likely that both fills post-date the demolition of Structure $G$ and are related to the use of the hearth associated with Structure H, placing the likely use of this structure somewhere between the 2 nd century $\mathrm{BC}$ and the first century AD.

Statistically the three dates relating to Structure $\mathrm{B}$ are contemporary, although the possibility that there were two phases of structures on the same site means that they may be only broadly so. The dolphin-type brooch from the palisade trench is typologically of the 1st-2nd centuries $\mathrm{AD}$, but this could date the end of use of the structure. No radiocarbon dates were obtained from Structure C, but the Roman headstud brooch found in the layer overlying the ring-ditch suggests that this layer and Structure B are likely to be broadly contemporary. Both brooches must have arrived at the site later than AD 70 (Section 4.3). 


\section{SITE INTERPRETATION AND DISCUSSION}

\subsection{Introduction}

Reconstruction of the site based on analyses of the arrangement of the post-holes has allowed an insight into the relationships amongst the various structures. Importantly, the excavation has shown that there are considerably more features on the ground than can be seen on the aerial photographs. Writing on the distribution of cropmarks on archaeological sites in Angus, Dunwell and Ralston (2008, 18) observed that 'there is something of the iceberg about them'. This statement certainly rings true at Seafield West, where only the larger post-built structures were visible among the background 'noise' of many other negative features.

Phasing of the site is hindered by the general lack of intercutting features which can be ascribed to individual structures. Nevertheless, the site is clearly multi-period and multi-phase, so an attempt has been made to provide it with a sequence on the basis of available dates, occasional stratigraphic evidence and spatial relationships. It is acknowledged that, like the structures themselves, a variety of other interpretations is possible. Potentially only three or four of these structures were standing at any given time, but overlap between the suggested phases of Period 2 is possible, and likely.

\subsection{Period 1 - Later Bronze Age}

The earliest occupation and activity within the excavated area appears to belong to the Late Bronze Age. All evidence of this date was found in the northwest area of the site, centred on Structure F. Whilst this structure could not be dated from the evidence available, the presence of fragments of sword mould (and the associated radiocarbon date AA-35528) in pits to both west and east, together with a fragment of pottery from a feature 'inside' it, are circumstantial evidence that this structure may belong to the same period. It has been reconstructed with a fairly long entrance passage (some $2.5 \mathrm{~m}$ ) to the $\mathrm{SSE}$, a feature which may also be present in Structure D to the south-west. It is therefore tentatively suggested, admittedly on the basis of no strong evidence, that these two structures may be contemporary.

\subsection{Period 2 - Iron Age}

Structure C, the ring-ditch house, was undated, but if it had an outer wall of turf, this would have covered one of the posts belonging to Structure D (assumed above to belong to Period 1). It would also have run very close to the penannular ditch of Structure B, which may indicate that it had been demolished before this was constructed. Work at Kintore (Cook \& Dunbar 2008) has suggested that the earlier ringditch houses there had external posts whilst later examples had an inner post-ring; the latter is felt to be the more likely interpretation of the features in Structure C, which may suggest that it fell towards the later end of the date range for these structures. The overlying layer 034 contained rimsherds of an Iron Age pot and a brooch of 1st to 2nd-century AD date (see Section 4.3). This may provide a terminus ante quem for the feature, rather than actually dating its use, depending upon how layer 034 is interpreted. It is interesting to note that a similar layer in a ringditch at Ironshill was interpreted as re-use of the feature as a small garden (Pollock 1997, 349). If so, it is likely to be this layer which was contemporary with the other Iron Age structures, suggesting that the ring-ditch house was earlier.

Structure G can be shown to be earlier than Structure $\mathrm{H}$ on the basis of stratigraphic evidence. Structure G's relationship with Structure H is determined by the hearth, assumed to belong to the latter, which cut one of the former's post-holes, and the presence of fired clay and slag in the post-holes of $\mathrm{G}$, which could have been deposited following its demolition and during the use of Structure $\mathrm{H}$.

Dates from the inner ring of Structure B and from $G$ suggest the two could be contemporary. Even if the radiocarbon dates from their post-holes represent their demolition rather than their use, these dates are statistically the same.

It is possible that the outer ring and penannular ditch of Structure B were later constructions than the inner ring, although it is impossible to determine how much later with the available evidence. Given the position of Structure C's entrance and the proximity of the ring-ditch to the penannular ditch, it seems likely that Structure C had been demolished by the time the ditch was dug.

Structure E, assumed to post-date Structure F, has a similar size and entrance alignment (possibly) so may have been contemporary with $\mathrm{B}$ and $\mathrm{G}$. Structure H appears to represent a less substantial structure than Structure G, which it replaced. Based on the presence of charcoal from its associated hearth in some of the upper fills of Structure G's post-holes, it seems likely that Structure H occupied the site only a short time after $\mathrm{G}$ had been demolished. The date from the charcoal cache (GU8032) shows a broad contemporaneity, although the charcoal from Structure G may date its demolition. Structure H appears to have had some kind of lean-to on the south side, and the double post-holes 
here may indicate that this feature was replaced at least once, or was long-lived enough to require shoring in its later years. This structure is assumed to represent a workshop related to metalworking activity, possibly U-shaped with an open side to the west.

Structure A was too poorly preserved and incomplete to be certain of its function or date, although the presence of oddly shaped shallow hollows close to it may indicate that animals used it for shelter; it may have been a palisaded enclosure rather than another roundhouse. It predated a post-medieval field ditch and a smaller, undated linear feature.

Structures I-J have been interpreted as representing a group of livestock pens. The sheer quantity of posts in this area suggests continual re-use of the area over a long period with shifts in alignment, but potentially there is evidence for a static entrance through a fenceline running along the north-east side of the settlement which remained unchanged despite the movement of posts to either side. As discussed above, there may also be evidence for an earlier domestic structure on this part of the site.

\subsection{The settlement and its setting within the landscape}

The presence of structures which may date to the Late Bronze Age has been suggested. This area of settlement was somewhat more recent than the nearby cemetery site in Area 1 (illus 2; Cressey \& Sheridan 2003), but could represent continuity of use in the area. Other Bronze Age finds in the vicinity have included a presumed Bronze Age burnt mound with complete wooden trough at Beechwood Farm (NH 69264525) approximately $200 \mathrm{~m}$ south of Seafield West (Cressey \& Strachan 2003) and a kerbed funerary monument at Raigmore (Simpson 1996), situated approximately $500 \mathrm{~m}$ from Area 2 . With the exception of a spearhead (Coles Class D) recovered from Inverness (NMRS NH64NE 29), there appear to be few finds of Late Bronze Age metalwork in the vicinity, although findspots are spread along the coast of the Moray Firth (Coles 1960).

Cropmark evidence representing possible Iron Age settlements has been widely recognised in Moray. The Moray Aerial Survey (Jones et al 1993) recorded a wide variety of cropmark features during the 1980 s in drought conditions. The cropmark sites at Flemington 2 (NGR NH 806519) and Brackla (NGR NH 852513), both close to the River Nairn, south-east of Nairn (see plates 4 and 7 in Jones et al 1993) display similarities with Seafield West in terms of the presence of a single entrance palisaded feature. The Flemington 2 site includes a large circular palisaded structure with internal postholes and, as is the case at Seafield West, a large number of features, possibly pits, form discrete clusters outside this structure. All three sites were situated in areas of former floodplain. In general terms, the character of the settlement can be paralleled at nearby Culduthel (Murray 2006), Birnie in Moray (summaries of seasonal excavations, eg Hunter 2003) and Kintore, Aberdeenshire (Cook \& Dunbar 2008). These large-scale excavations of Iron Age settlements contain a variety of roundhouse types alongside four- and six-posters, palisaded stock enclosures, metalworking evidence and other more enigmatic features; most are ongoing projects in the process of analysis at the time of writing.

The character of the landscape at Seafield West, supported by evidence from both early cartographic sources and modern soil maps, shows that the settlement was confined to the edge of a floodplain, or marshy area of the Inshes, a region of low-lying ground. It is highly probable in general that the margins of low-lying marshy ground were favoured for occupation due to the greater diversity of exploitable wetland resources (cf Evans 1992; Needham \& Macklin 1992). Cultivation of field systems higher on the south-facing slopes and on the gravel ridge overlooking the settlement could have been extensive, given the ease of tillage on these light sandy soils. The recovery of charred cereal remains indicates that the occupants of the site were involved in cereal production and processing. The cereal remains point to the production of barley, a crop well suited to the area (see below). The presence of tubers and rhizomes identified in the plant assemblage perhaps indicates that turf may have been used for fuel or indeed roofing material. The large areas of fire-reddened soil with the section above and adjacent to a small oven in Structure C equally suggest prolonged use of turf or peat as a fuel.

The absence of local pollen diagrams from the immediate vicinity limits the discussion on woodland development along the coastal edge of the Moray Firth. Indirect evidence based on roundwood charcoal and carbonised seed remains does however provide tentative evidence on the character of the landscape around Seafield West at the time of its occupation. The charred remains of hazelnuts and the charcoal assemblage show that birch and hazel were readily available. These trees would have thrived on the potentially acidic soils bordering the fluvioglacial ridge overlooking the Moray Firth. Oak is very tolerant of base-poor soil (Wilkinson 1975, 55-66) and would have thrived on the edge of the floodplain. It is a matter of conjecture whether sufficient quantities of oak for smithing purposes were readily available. Some $12 \%$ of the charcoal identified within the cache associated with the hearth within Structure G was carpentry debris. It seems likely that oak was recognised by the metalworkers as providing better-quality charcoal for smithing.

The presence of prestigious metalwork in the form of two ornate copper alloy brooches fits well with the theory that the occupants of the site were of a fairly high status with access to luxury goods. The distribution of artefacts and coin hoards so far recorded within the Inverness-Elgin region may well be linked to the agricultural potential of the region, as has been noted by Hunter (above). Examination 
of modern soil maps for this area shows that from Seafield West eastwards to the Lossiemouth area the soils are predominantly classified as the Corby and Boyndie Associations which are formed from humus iron podsols found widely on river terraces and raised beach deposits; they equally characterise other extensively cropmarked areas, such as the lower Lunan Valley in Angus. The Moray-Inverness lowlands today have a rainfall comparable to warm dry lowlands elsewhere at $700 \mathrm{~mm}$ per year, a rainfall trend which is conducive to barley production. In Britain, barley growth is only restricted in areas of poor drainage and in acid soils where $\mathrm{pH}$ is lower than 6 (Jones 1996 citing Bland 1971). The agricultural potential of the region in the first century $\mathrm{AD}$ must have been good, with only nutrient status and drainage, along with variability in climate, being factors limiting crop production. The generation of crop surpluses may have stimulated a concentration of wealth along the coastal plain of the Moray Firth, although other factors such as the elite powerstructure and trading links via a maritime route, alongside possible biases in the archaeological record, might play a part in the distribution pattern of prestigious finds from this area.

We cannot be certain to what extent the consumption of iron and its manufacture into tools influenced or led to increased status of members of the community at Seafield West. In the light of these results it is clear that some of the occupants were of high status, a status gained perhaps from control of crop production and surplus. The site's position, just along the coast from the mouth of the River Ness and the junctions of the Beauly and Moray Firths, perhaps provided greater access to trading partners connected by well-established maritime networks along this part of the coastline.

\subsection{Conclusions}

The excavations at Seafield West have achieved their primary objective in mitigating the loss of archaeological features recorded as cropmarks. It is clear from the excavation that the density of archaeological features actually present exceeds those that are visible from cropmark evidence and geophysical survey by well over $200 \%$. The wealth of palaeobotanical remains recovered from environmental processing shows that arable agriculture apparently formed the mainstay of the economy at the site, although the acidic nature of the subsoils negates the survival of animal bone thus skewing the economic record in favour of carbonised plant remains. Additional evidence gained from the weed spectrum shows that cultivated land was close to the site and the identification of a 'marginal' plant spectrum suggests that local floodplain environments were also exploited.

The suggestion that Seafield West may represent one of the earliest radiocarbon-dated smithing sites in Scotland adds a new dimension to the value of large-scale excavation on cropmark sites. Although much of the slag examined from the site was derived from secondary contexts, the slag assemblage as a whole has provided a wealth of data to support the theory that both smelting and smithing were being practised, even though none of the products of this craft were recovered. These iron-smithing remains are an all-too-rare survival of what must have been an everyday occurrence on most settlements. When slag and industrial remains are recovered they are generally dispersed far from their original context: here the focus of metalworking was found, with evidence of forging in a pit-hearth. As Heald discusses, there remain problems of interpretation, but this is a valuable addition to the record.

Metalworking activity appears to have been undertaken during both the Late Bronze Age and the Late Iron Age, although there is insufficient evidence at the site to suggest continuity of settlement. Answers to many of the questions posed by the excavation at Seafield may well be forthcoming as reports on larger contemporary settlement excavations become available in the near future. 


\section{ACKNOWLEDGEMENTS}

Mike Cressey wishes to thank Jamie Hamilton, who was joint supervisor on this project, and all those involved both with the earlier site evaluation work and later excavation of the site. He would also like to thank all the specialists for their individual contributions to this report. Final illustrations were prepared by Leeanne Whitelaw and Alan Braby. Dorothy Maxwell, Highland Council, is thanked for her assistance during the excavation. Fraser Hunter is grateful to Siobhan Ratchford for information on similar brooches in Dumfries Museum. Gordon Milne, of Inverness Retail Park Limited, is thanked for his logistic and financial support. Earlier drafts of this paper were read and commented upon by Andrew Dunwell and Ian Ralston. Finally, this paper is dedicated to the late Ken Browell, who was a valued team member on both of the Seafield West projects. While thanks are due to the above, responsibility for the content of this paper lies with the authors and CFA Archaeology Ltd. 


\section{REFERENCES}

Alexander, D $2000^{`}$ Excavation of Neolithic pits, later prehistoric structures and a Roman temporary camp along the line of the A96 Kintore and Blackburn Bypass, Aberdeenshire', Proc Soc Antiq Scot, 130, 11-75.

Anderson, J 1905 'Notes on a Romano-British hoard of bronze vessels and personal ornaments found in a moss on Lamberton Moor, Berwickshire', Proc Soc Antiq Scot, 39 (1904-05), 367-76.

Ashmore, P J 1999 'Radiocarbon dating: avoiding errors in dating by avoiding mixed samples', Antiquity 73 (1999), 124-30.

Bachmann, H G 1982 The Identification of Slags from Archaeological Sites. London (= Inst Archaeol Univ London Occ Paper, 6).

Bateson, J D 1989 'Roman and medieval coins found in Scotland, to 1987', Proc Soc Antiq Scot, 119 (1989), 165-88.

Bateson, J D \& Holmes, N M McQ 1997 'Roman and medieval coins found in Scotland, 1988-95', Proc Soc Antiq Scot 127 (1997), 527-61.

Bateson, J D \& Holmes, N M McQ 2003 'Roman and medieval coins found in Scotland, 1996-2000', Proc Soc Antiq Scot, 133 (2003), 245-76.

Benton, S 1931 'The excavation of the Sculptor's Cave, Covesea, Morayshire', Proc Soc Antiq Scot, 65 (1930-31), 177-216.

Bersu, G 1947 "Fort” at Scotstarvit Covert, Fife', Proc Soc Antiq Scot, 82 (1947-48), 241-63.

Boyd, B 1988 'Cereals in Scottish antiquity', Circaea, 5(2), 101-10.

Bland, B L 1971 Crop Production: cereals and legumes. Academic Press, London.

Callander, J G 1918 'Notice of a harp-shaped fibula found on the estate of Polmaise, Stirlingshire, and of another in the Perth Museum', Proc Soc Antiq Scot, 52 (1917-18), 26-31.

Cameron, K 1999 'Excavation of an Iron Age timber structure beside the Candle Stane recumbent stone circle, Aberdeenshire', Proc Soc Antiq Scot, 129 (1999), 359-72.

Clarke, A 1996 Observations of Social Change in Prehistoric Orkney and Shetland based on the Type and Context of Coarse Stone Tools. MLitt thesis, Univ Glasgow.

Clarke, A 1998 'The Stone', in L Main, 377-90.

Clarke, A 2007 'Coarse stone', in I Armit Anatomy of an Iron Age Roundhouse. The Cnip Wheelhouse Excavations, Lewis, 151-3. Soc Antiq Scot, Edinburgh.

Clapham, A R; Tutin, T G \& Moore, D M 1987 Flora of the British Isles. 3rd edn. Cambridge Univ Press, Cambridge.

Coles, J M 1960 'Scottish Late Bronze Age metalwork: typology, distributions and chro- nology', Proc Soc Antiq Scot, 93 (1959-60), $16-134$.

Coleman, R \& Hunter, F 2002 'The excavation of a souterrain at Shanzie Farm, Alyth, Perthshire', Tayside Fife Archaeol J, 8, 77-101.

Coles, J M 1960 'Scottish Late Bronze Age metalwork: typology, distribution and chronology', Proc Soc Antiq Scot, 93 (1959-60), 16-134.

Collingwood, R G \& Richmond, I A 1969 The Archaeology of Roman Britain. 2nd edn. Methuen, London.

Collins, A E P 1970 'Bronze Age moulds in Ulster', Ulster J Archaeol, 33, 23-36.

Cook, M \& Dunbar, L 2008 Rituals, Roundhouses and Romans: Excavations at Kintore, Aberdeenshire 2000-20006, Volume 1: Forest Road. Edinburgh (=STAR Monogr 8).

Cowie, T \& O'Connor, B 2007 'Late Bronze Age swords from Scotland: some finds old and new', in C Burgess; P Topping \& F Lynch (eds) Beyond Stonehenge. Essays on the Bronze Age in Honour of Colin Burgess, 316-34. Oxford.

Cree, J E \& Curle, A 1922 'Account of the excavation on Traprain Law during the summer of 1921', Proc Soc Antiq Scot, 56 (1921-22), 189-259.

Cressey, M \& Finlayson, B 1996 Archaeological Site Evaluation at Seafield West. Inverness, Highland Region. CFA Report No. 273. Unpublished.

Cressey, M \& Sheridan, A 2003 'The excavation of a Bronze Age cemetery at Seafield West, near Inverness, Highland', Proc Soc Antiq Scot, 133 (2003), 47-84.

Cressey, M \& Strachan, R 2003 'The excavation of two burnt mounds and a wooden trough near Beechwood Farm, Inshes, Inverness, 1999', Proc Soc Antiq Scot, 133 (2003), 191-203.

Curle, J 1911 A Roman Frontier Post and its People. Maclehose, Glasgow.

Curle, A O 1933 'Account of further excavations in 1932 of the prehistoric township at Jarlshof, Shetland, on behalf of HM Office of Works', Proc Soc Antiq Scot, 67 (1932-33), 82-136.

Curle, A O 1934 'An account of further excavation at Jarlshof, Sumburgh, Shetland, in 1932 and 1933, on behalf of HM Office of Works', Proc Soc Antiq Scot, 68 (1933-34), 224-319.

Curle, A O \& Cree, J E 1921 'Account of the excavations on Traprain Law during the summer of 1920', Proc Soc Antiq Scot, 55 (1920-21), 153-206.

Dickson, C 1994 'The Plant Remains', in B Ballin Smith (ed) Howe. Four Millennia of Orkney Prehistory Excavations 1978-1982. Edinburgh (= Soc Antiq Scot Monogr, 9). 
DES: Discovery and Excavation in Scotland. Council for Scottish Archaeology, Edinburgh.

Dunwell, A \& Ralston, I 2008 Archaeology and Early History of Angus. Tempus, Stroud.

Dunwell A 2007 Cist Burials and an Iron Age Settlement at Dryburn Bridge, Innerwick, East Lothian. Scottish Archaeological Internet Reports No. 24, www.sair.org.uk.

Ellison, A \& Drewett, P 1971 'Pits and post-holes in the British Early Iron Age: some alternative explanations', Proc Prehist Soc, 37(1), 183-94.

Eremin, K 2000 Analysis of mould fragments from Seafield, Inverness. NMS Analytical Research Section Report No 00/12. Unpublished report.

Evans, J G 1992 'River valley bottoms and archaeology in the Holocene', in B Coles (ed) The Wetland Revolution in Prehistory, 47-54. Exeter (= WARP Occ Pap, 6).

Fenton, A 1978 The Northern Isles: Orkney and Shetland. John Donald, Edinburgh.

Gillies, W 1981 'The craftsman in early Celtic literature', Scott Archaeol Forum, 11, 70-85.

Guido, M 1978 The Glass Beads of the Prehistoric and Roman Periods in Britain and Ireland. London (=Soc Antiq Lond Res Rep, 35).

Hattatt, R 1985 Iron Age and Roman Brooches. Oxbow, Oxford.

Henderson, J 1989 'The evidence for regional production of Iron Age glass in Britain', in M Feugère (ed), Le verre préromain en Europe occidentale, 63-72. Editions Monique Mergoil, Montagnac.

Henderson, J 1994 'The glass', in B Ballin Smith (ed), Howe: Four Millennia of Orkney Prehistory, 234-6. Edinburgh (= Soc Antiq Scot Monogr, 9).

Henig, M 1971 'Three Roman Objects from the Culbin Sands, Morayshire', Proc Soc Antiq Scot, 103 (1970-71), 231-3.

Hingley, R 1992 'Society in Scotland from 700 вс to AD 200', Proc Soc Antiq Scot, 122 (1992), 7-53.

Hingley, R 1997 'Iron, ironworking and regeneration: a study of the symbolic meaning of metalworking in Iron Age Britain', in A Gwilt \& C Haselgrove (eds) Reconstructing Iron Age Societies: New Approaches to the British Iron Age, 9-18. Oxford (= Oxbow Monogr, 71).

Hingley, R; Moore, H L; Triscott, J E \& Wilson, G 1997 'The excavation of two later Iron Age fortified homesteads at Aldclune, Blair Atholl, Perth and Kinross', Proc Soc Antiq Scot, 127 (1997), 407-66.

Hodges, H 1954 'Studies in the Late Bronze Age in Ireland: 1. Stone and clay moulds, and wooden models for bronze implements', Ulster $J$ Archaeol, 17, 62-80.

Hodges, H 1959 'The Bronze Age moulds of the British Isles. Part 1: Scotland and Northern England - moulds of stone and clay', Sibrium, 4, 129-37.

Hodges, H 1989 Artefacts. An introduction to early materials and technology, Ch 15, 168. Duckworth, London.

Holmes, N M McQ 2006 'Two denarius hoards from Birnie, Moray', British Numismatic J 76, 1-44.
Hunter, F 1996 'Recent Roman Iron Age metalwork finds from Fife and Tayside', Tayside Fife Archaeol J, 2, 113-25.

Hunter, F 1998 'Lead', in L Main, 352-6.

Hunter, F 2001 'Roman and native in Scotland: new approaches', J Roman Archaeol 14, 289-309.

Hunter, F 2003 Excavations at Birnie, Moray, 2002. Unpublished report, Dept of Archaeol, National Museums of Scotland.

Hunter, F 2007 Beyond the Edge of the Empire: Caledonians, Picts and Romans. Groam House Museum, Rosemarkie.

Hunter, F, Cowie, T \& Heald, A 2007 'Research priorities for archaeometallurgy in Scotland', Scott Archaeol J, 28(1), 49-62.

Johnston, D A 1994 'Carronbridge, Dumfries and Galloway: the excavation of Bronze Age cremations, Iron Age settlements and a Roman camp', Proc Soc Antiq Scot, 124 (1994), 233-91.

Jones, M 1996 'Plant exploitation', in T C Champion \& J R Collis (eds) The Iron Age in Britain and Ireland: Recent Trends, 29-40. Edinburgh.

Jones, B; Keiller, I \& Maude, K 1993 'The Moray Aerial Survey - discovering the prehistoric and proto-historic landscape', in W D H Sellar (ed) Moray: Province and People. Scottish Society of Northern Studies, Edinburgh.

Kendrick, J 1995 'Excavation of a Neolithic enclosure and an Iron Age settlement at Douglasmuir, Angus', Proc Soc Antiq Scot, 125 (1995), 29-67.

Macinnes, L 1984 'Brochs and the Roman occupation of lowland Scotland', Proc Soc Antiq Scot, 114 (1984), 235-49.

Mackreth, D F 1996a 'Brooches', in R Jackson \& T W Potter Excavations at Stonea, Cambridgeshire, 1980-85, 296-327. British Museum Press, London.

Mackreth, D F 1996b 'The bronze brooch', in D Simpson, 77.

McDonnell, G 1986 The Classification of Early Ironworking Slags. PhD thesis, Aston Univ.

McDonnell, G 1994 'Slag report', in B Ballin Smith (ed) Howe: Four Millennia of Orkney Prehistory, 228-34. Edinburgh (= Soc Antiq Scot Monogr, 9).

McDonnell, G 1998 'Irons in the fire - evidence of ironworking on broch sites', in Nicholson \& Dockerill, 150-62.

Main, L 1998 'Excavation of a timber round-house and broch at the Fairy Knowe, Buchlyvie, Stirlingshire, 1975-8', Proc Soc Antiq Scot, 128 (1998), 293-417.

Murray, R 2006 'Excavation of an Iron Age settlement and industrial centre near Inverness', History Scotland, Sept/Oct 2006.

Needham, S 1996 'Chronology and periodisation in the British Bronze Age', in K Randsborg (ed) Absolute Chronology. Archaeological Europe 2500-500 BC. Copenhagen 1996, 121-40.

Needham, S; Bronk Ramsey, C; Coombs, D; Cartwright, C \& Pettitt, P 1997 'An independent chronology for British Bronze Age metalwork: 
the results of the Oxford Radiocarbon Accelerator Programme', Archaeol J, 154 (1997), 55-107.

Needham, S \& Macklin, M G (eds) 1992 Alluvial Archaeology in Britain: Proceedings of a Conference sponsored by the RMC Group plc. Oxford (= Oxbow monogr, 27).

Nicholson, R A \& Dockerill, S J 1998 Old Scatness Broch, Shetland: Retrospect and Prospect. Bradford.

Nye, S \& Jones, M 1987 'The carbonised plant remains', in B Cunliffe Hengistbury Head, Dorset vol 1: The prehistoric and Roman Settlement $3500 B C-A D$ 500, 323-63. Oxford (= Oxford Univ Cttee for Archaeol Monogr, 13).

Pollock, D 1997 'The excavation of Iron Age buildings at Ironshill, Inverkeilor, Angus', Proc Soc Antiq Scot, 127 (1997), 339-58.

Pope, R 2003 Prehistoric Dwelling: circular structures in north and central Britain c $2500 B C-A D$ 500. Unpub. PhD Thesis, Univ of Durham.

Ratcliffe, J \& Straker, V 1996 The Early Environment of Scilly: palaeoenvironmental assessment of cliff-face and intertidal deposits 1989-1993. Cornwall Archaeol Unit, Truro.

Rideout, J S (ed) 1996 'Excavation of a promontory fort and a palisaded homestead at Lower Greenyards, Bannockburn, Stirling, 1982-5', Proc Soc Antiq Scot, 126 (1996), 199-269.

Robertson, A 1970 'Roman finds from non-Roman sites in Scotland', Britannia, 1, 198-226.

Robertson, A 1978 'The circulation of Roman coins in North Britain: the evidence of hoards and site-finds from Scotland', in R A G Carson \& C M Kraay (eds), Scripta Nummaria Romana: Essays presented to Humphrey Sutherland, 186-216. Spink, London.

Robertson, A 1983 'Roman coins found in Scotland, 1971-82', Proc Soc Antiq Scot, 113 (1983), 405-48.

Russell-White, C J 1995 'The excavation of a
Neolithic and Iron Age settlement at Wardend of Durris, Aberdeenshire', Proc Soc Antiq Scot, 125 (1995), 9-27.

Salter, C \& Ehrenreich, R 1984 'Iron Age metallurgy in central southern Britain', in B Cunliffe \& D Miles (eds) Aspects of the Iron Age in Central Southern Britain, 146-61. Oxford (= Oxford Univ Cttee Archaeol Monogr, 2).

Scott, B G 1990 Early Irish Ironworking. Ulster Museum, Belfast.

Shepherd, I A G 1993 'The Picts in Moray', in W D H Sellar (ed), Moray: Province and People, 75-90. Scottish Society for Northern Studies, Edinburgh.

Simpson, D 1996 'Excavation of a kerbed funerary monument at Stoneyfield, Raigmore, Inverness, Highland, 1972-3', Proc Soc Antiq Scot, 126, $53-86$.

Snape, M E 1993 Roman Brooches from North Britain. Oxford (=Brit Archaeol Rep, Brit Ser, 235).

Tylecote, R F 1986 The Prehistory of Metallurgy in the British Isles. London.

Van der Veen, M 1991 'Consumption or production? Agriculture in the Cambridgeshire Fens', in J Renfrew (ed) New Light on Early Farming, Recent Developments in Palaeoethnobotany. Edinburgh.

Webster, J 1981 'The Bronzes', in M G Jarrett \& S Wrathmell Whitton: An Iron Age and Roman Farmstead in South Glamorgan, 163-88. University of Wales Press, Cardiff.

Webster, J 1995 'Brooches', in W H Manning Report on the Excavations at Usk

1965-1976: The Roman Small Finds, 60-96. University of Wales Press, Cardiff.

Wilkinson, G 1975 Trees in the Wild. Book Club Associates, London.

Wordsworth, J 1999 'A later prehistoric settlement at Balloan Park, Inverness', Proc Soc Antiq Scot, 129 (1999), 239-49. 


\section{APPENDIX 1 ROMAN FINDS FROM THE MORAY FIRTH (ILLUS 12)}

Note that the following coins from eastern mints are ignored as likely modern introductions: Alexandrian tetradrachm of Aurelian from Fortrose; three Ptolemaic bronzes and an eastern mint bronze of Constantinian from Dingwall; Alexandrian bronze of Carinus from Cummingstown; Alexandrian 3rdcentury bronze from Mortlach; Alexandrian bronze of Galerius from Elgin; Greek bronze of Nero from Burghead.

\begin{tabular}{|c|c|c|}
\hline Location & Date & Reference \\
\hline \multicolumn{3}{|l|}{ Coins } \\
\hline Burghead & Magnentius, Gallienus & Robertson 1983 \\
\hline Cromarty & Hadrian AR & Bateson \& Holmes 1997 \\
\hline Culloden & Commodus & Bateson \& Holmes 1997 \\
\hline Dingwall & Constantine I (modern loss?) & Bateson \& Holmes 2003 \\
\hline Dornoch & Agrippa & Robertson 1983 \\
\hline Elgin & Sabina, Antoninus Pius, Faustina I, Julia Mamaea & Robertson 1983 \\
\hline Forres & $\begin{array}{l}\text { Titus, Constantinopolis } \\
\text { Honorius, Unspecified }\end{array}$ & $\begin{array}{l}\text { Robertson } 1983 \\
\text { Bateson } 1989\end{array}$ \\
\hline Fortrose & Augustus Divus, Nero & Robertson 1983 \\
\hline Hilton, Inverness & Antoninus Pius & Robertson 1983 \\
\hline Inverness & Magnus Maximus & Robertson 1983 \\
\hline Kirkhill, Alves & Tetricus II & Bateson \& Holmes 2003 \\
\hline Lossiemouth & Domitian/Trajan & Bateson \& Holmes 1997 \\
\hline Lossie Green & Constantius I & Bateson \& Holmes 1997 \\
\hline Mortlach & Marcus Aurelius, M Aurelius/L Verus, Maximinus & Robertson 1983 \\
\hline Nigg & Constantius II & Robertson 1983 \\
\hline Nine Stanes, Urquhart & Vespasian & Bateson \& Holmes 2003 \\
\hline Portmahomack & Tetrici & Robertson 1983 \\
\hline Speyslaw, Garmouth & Vespasian Divus AR & Bateson \& Holmes 2003 \\
\hline \multicolumn{3}{|l|}{ Coin hoards } \\
\hline Bean Castle, Nairn & Hoard of uncertain date & Robertson 1978 \\
\hline Birnie & Two silver hoards, AD 193 and 196 & Holmes 2006 \\
\hline Nairn & Silver hoard, undated & Robertson 1978 \\
\hline Sculptor's Cave, Covesea & Bronze hoard to Constantius Gallus ( $c$ AD 354) & Robertson 1978 \\
\hline Tain Sands, Morrich & Hoard of uncertain date & Unpublished old discovery \\
\hline \multicolumn{3}{|l|}{ Other Roman artefacts } \\
\hline Achinchanter, Dornoch & Three trumpet brooches & DES 1995, 47; 1996, 61 \\
\hline Auldearn & Bronze vessel (handled dipper) & Britannia 36, 2005, 393, fig 5 \\
\hline Brackla, Cawdor & Samian & DES 1990, 24 \\
\hline Burghead & Melon bead & Robertson 1970 \\
\hline Charlestown & Three brooches (trumpet, headstud, plate-on-bow) & Hunter 2007 App 3; \& unpub \\
\hline Culbin Sands & $\begin{array}{l}\text { Three trumpet brooches or variants, } 1 \text { T-brooch, glass, } \\
\text { zoomorphic furniture leg, signet ring }\end{array}$ & Robertson 1970; Henig 1971 \\
\hline Culduthel & $\begin{array}{l}\text { Plate-on-bow brooch } \\
\text { Two bronze coins }\end{array}$ & British Archaeology Jan/Feb 2007, 6 \\
\hline
\end{tabular}




\begin{tabular}{lll}
\hline Location & Date & Reference \\
\hline Dores & Aucissa brooch & Robertson 1970 \\
Lochhill, Urquhart & Bar brooch & Hunter 2007, Appendix 3 \\
Lochside, Spynie & Trumpet brooch & Robertson 1970 \\
Moray Firth & Crossbow brooch & Robertson 1970 \\
Portmahomack & Intaglio & Unpublished \\
Sculptor's Cave, Covesea & Samian, toilet instruments, glass, padlock bolt & Robertson 1970 \\
Stonewells, Urquhart & Headstud brooch & Hunter 2007, Appendix 3 \\
Seafield West, Inverness & Two brooches & This paper \\
Stoneyfield, Raigmore & Headstud brooch, coarse ware & Mackreth 1996b \\
\hline
\end{tabular}




\section{APPENDIX 2 SLAG CATALOGUE}

\begin{tabular}{|c|c|c|c|c|c|c|c|}
\hline Cat. no. & Context & Feat & Type & $\mathbf{L}$ & $\mathbf{H}$ & $\mathbf{W}$ & Wt (g) \\
\hline 001 & 175 & 175 & Vitrified mass/cinder & 54 & 28 & 42 & 48 \\
\hline 002 & 128 & 127 & Hearth lining & 68 & 42 & 27 & 53 \\
\hline 003 & 180 & 181 & Hearth lining & 49 & 19 & 50 & 42 \\
\hline 004 & 412 & 411 & Hearth lining & 30 & 19 & 22 & 102 \\
\hline 005 & 363 & 364 & Hearth lining & 48 & 38 & 21 & 36 \\
\hline 006 & 188 & 181 & Hearth lining & 71 & 54 & 32 & 99 \\
\hline 007 & 096 & 004 & Runned slag & 75 & 36 & 53 & 122 \\
\hline 008 & 128 & 127 & $\begin{array}{l}\text { Slag amalgam including a plano-convex slag cake(s). } \\
\text { ?Smithing hearth bottom(s) and attached hearth lining. }\end{array}$ & 130 & 79 & 80 & 1187 \\
\hline 009 & 128 & 127 & $\begin{array}{l}\text { Slag amalgam (two pieces) including plano-convex slag } \\
\text { cakes? Smithing hearth bottom and attached hearth lining. }\end{array}$ & 110 & 65 & 92 & 574 \\
\hline 010 & 060 & 055 & Plano-convex slag cake. ?Smithing hearth bottom. & 62 & 18 & 58 & 92 \\
\hline 011 & 179 & 181 & Plano-convex slag cake(s). ?Smithing hearth bottom(s). & 78 & 35 & 69 & 209 \\
\hline 012 & 005 & 004 & Plano-convex slag cake(s). ?Smithing hearth bottom(s). & 114 & 49 & 99 & 589 \\
\hline 013 & 096 & 004 & Plano-convex slag cake(s). ?Smithing hearth bottom(s). & 78 & 34 & 65 & 272 \\
\hline 014 & 128 & 127 & Accumulated smithing hearth bottoms. & 200 & 60 & 180 & 2000 \\
\hline 015 & 057 & 054 & Unclassified slag. Likely to derive from smithing. & & & & 107 \\
\hline 016 & 188 & 181 & Unclassified slag. Likely to derive from smithing. & & & & 108 \\
\hline 017 & 156 & 155 & Unclassified slag. Likely to derive from smithing. & & & & 128 \\
\hline 018 & 161 & - & Unclassified slag. Likely to derive from smithing. & & & & 31 \\
\hline 019 & 128 & 127 & $\begin{array}{l}\text { Many fragments of nodular slag lumps. Unclassified slag. } \\
\text { Likely to derive from smithing. Also contains slag spheres } \\
\text { and small amounts of hammerscale. Found during trowel- } \\
\text { ling and soil sample residues. }\end{array}$ & & & & 1920 \\
\hline 020 & $\mathrm{U} / \mathrm{s}$ & - & Unclassified slag. Likely to derive from smithing. & & & & 117 \\
\hline 021 & 367 & 368 & Unclassified slag. Likely to derive from smithing. & & & & 178 \\
\hline 022 & 412 & 411 & Unclassified slag. Likely to derive from smithing. & & & & 53 \\
\hline 023 & 005 & 004 & Unclassified slag. Likely to derive from smithing. & & & & 385 \\
\hline 024 & 128 & 127 & Unclassified slag & & & & 2 \\
\hline 025 & 128 & 127 & Unclassified slag & & & & 1 \\
\hline 026 & 175 & 175 & $\begin{array}{l}\text { Unclassified slag. One piece very magnetic - possibly an } \\
\text { object. }\end{array}$ & & & & 6 \\
\hline 027 & 285 & 124 & Unclassified slag. & & & & 5 \\
\hline 028 & 209 & 208 & Unclassified slag & & & & 2 \\
\hline 029 & $115 / 136$ & - & Unclassified slag & & & & 43 \\
\hline 030 & $\mathrm{U} / \mathrm{s}$ & - & Unclassified slag & & & & 24 \\
\hline 031 & 153 & 154 & Unclassified slag & & & & 6 \\
\hline 032 & 093 & 094 & Unclassified slag & & & & 3 \\
\hline 033 & 062 & 061 & Unclassified slag & & & & 9 \\
\hline 034 & $\mathrm{U} / \mathrm{s}$ & - & Unclassified slag & & & & 139 \\
\hline 035 & 097 & 004 & Unclassified slag & & & & 11 \\
\hline 036 & 034 & - & Unclassified slag & & & & 3 \\
\hline 037 & 025 & 026 & Unclassified slag & & & & 1 \\
\hline Total & & & & & & & 8707 \\
\hline
\end{tabular}

Note: $\mathrm{L}$ - length; $\mathrm{H}$ - height/thickness; $\mathrm{W}$ - width - measurements in $\mathrm{mm}$. 